Historic, Archive Document

Do not assume content reflects current scientific knowledge, policies, or practices. 



\section{GARDEN-FLOWER and FIELD SEED}
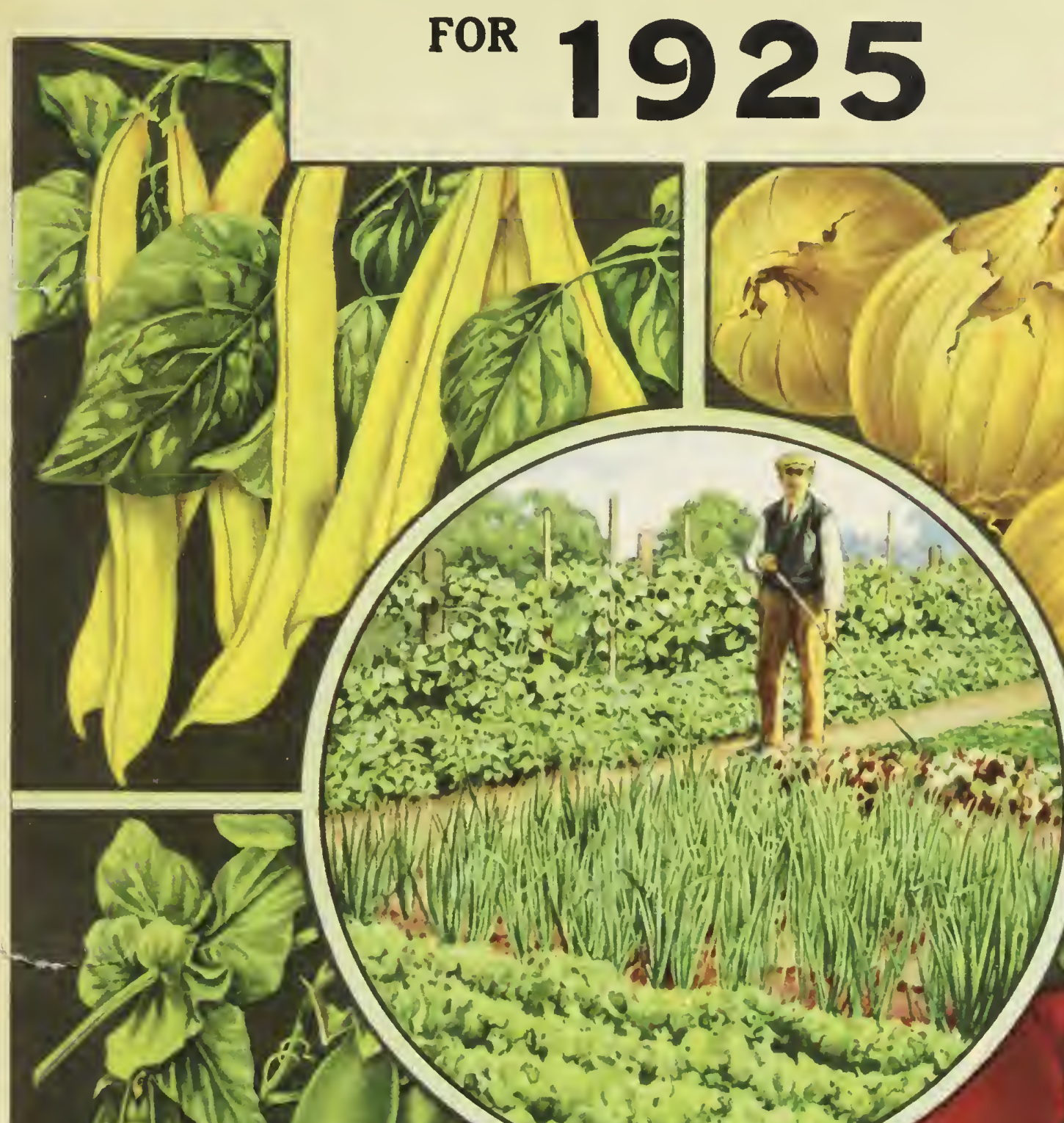

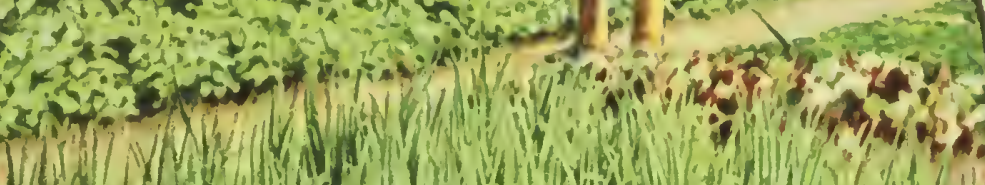

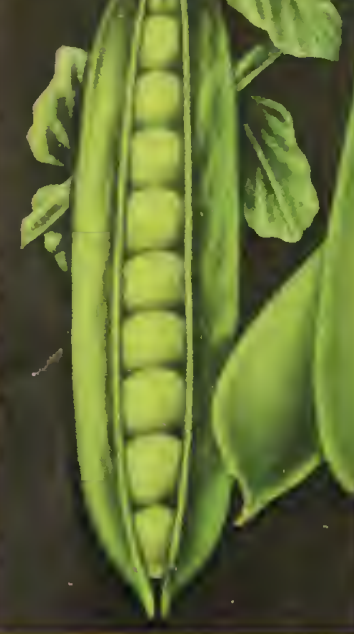

\section{SPRINGFIELD SEED CO.}

Campbell and Walnut Streets

SPRINGFIELD, MISSOURI
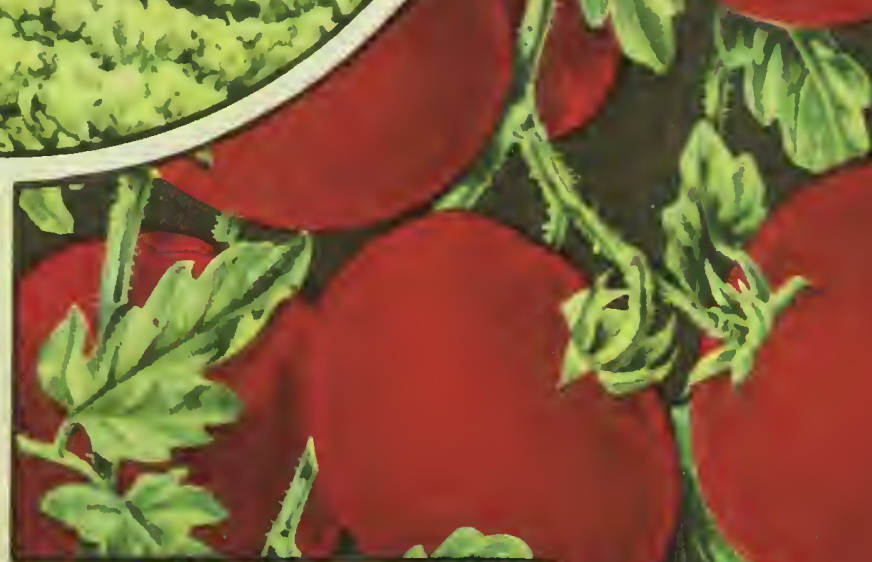


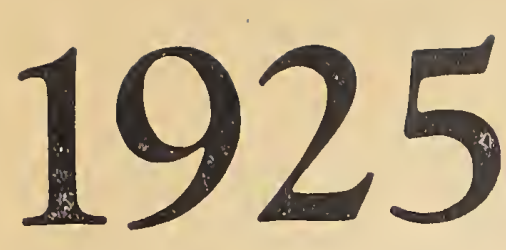

THE DEPENDABLE

\section{INDEX}

\section{FLOWER SEED}

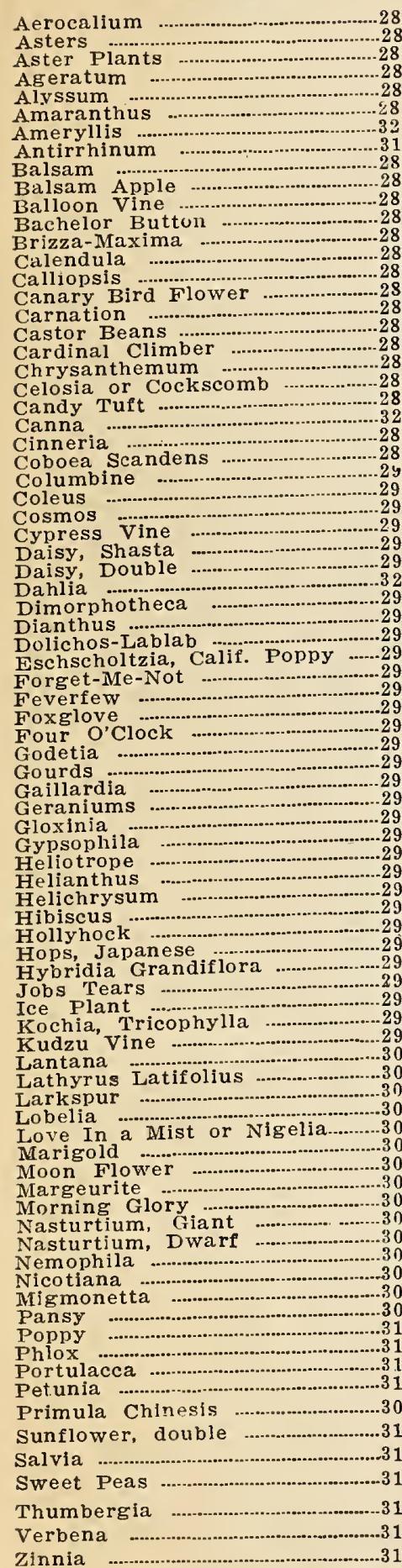

Rose Bushes ................Back Cover BRAND

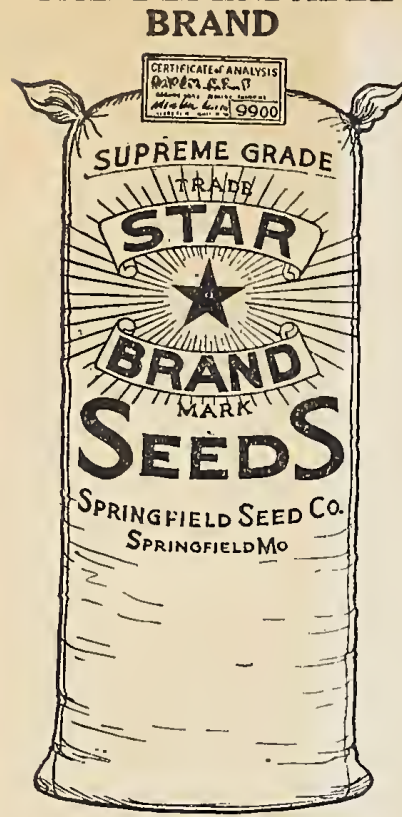

GARDEN SEEDS

Artichoke

Asparagus

Beets, Table

Beets, Sugar

Beans, Wax

Beans, Lima

Broccoli

Brussels Sprouts

Carrots

Corn, Sweet

Cabbage

Corn Salad

Cauliflower

Caulify

Chives

Celeriac
Celeric

Celeric ......
Egg Plant
Fndive ....

Garlic

Garlic

Horseradish Roots

Kale

Kohl Rabi

Lettuc

Muskmelon

Mustard

Okra

Onion Seed

Onion Sets

Oriental Seed

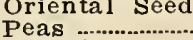

Parsnip

Pepper

Pimento

Peanuts

Pop Corn

Potatoes

Pumpkin

Rhubarb, or Pie Plant

Ruta Baga

Sage

Salsify

Spinach

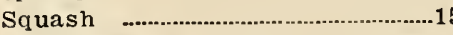

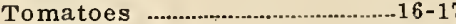

Turnips …..

Tobacco Seed ……………-........10

Vegetable Plants ………….............14

Watermelon ………............................19
When the curtain is pulled back for the spring planting and gardening of 1925 we want to call your attention to the listings of this, our 30th Catalog. We have, as has been our custom for years rated only true and tried varieties, which has proven their worth by years of trial. Their quality has been improved by propagation and years of careful attention by our expert seed growers, which insures you the highest quality of seed obtainable. Analyzed for Purity, Tested for Germination and packed under our STAR BRAND standard, we feel that the pleasure of your spring crop will be all yours.

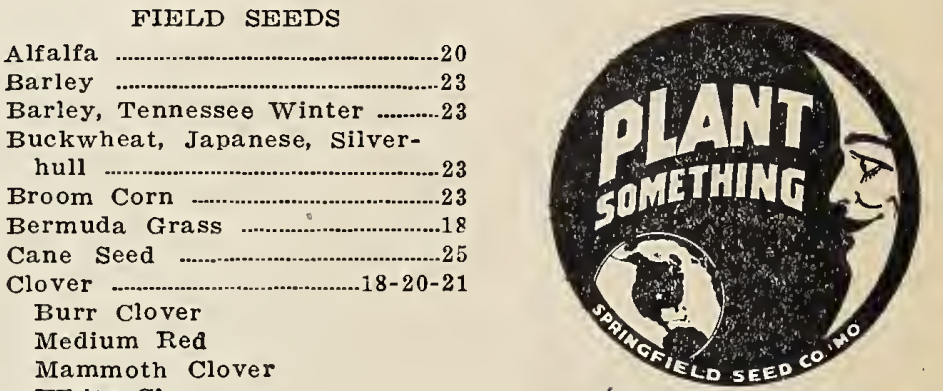

White Clover

Japan Clover

Crimson Clover

Alsike Clover

Sainfoin Clover or Esparsette Sweet Clover

Corn, Field ..................................22-23

Corn, Brazillian Flower ...............23

Corn, Sweet, for Fodder..............22

Cow Peas ...........................................26

Egyptian Wheat ..............................25

Feterita ................................................25

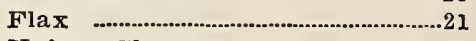

Huban Clover ..................................21

Hungarian Brome ..........................21

Italian Rye ..........................................24

Johnson Grass ..................................24

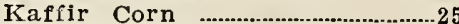

Kentucky Blue Grass ...................18

Lawn Grass Seed ...........................18

Millet ...................................................25

Milo Maize ..........................................24

Meadow Fescue, or English

Blue Grass

Oats, seed ..............................................24

Orchard Grass ......................................21

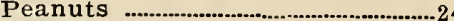

Red Top ..............................................24

Rye .........................................................23

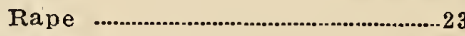

Speltz ...................................................21

Sudan Grass .......................................24

Soy, or Soja Beans ........................26

Timothy ....................................................21

Teosinte ..................................................24

Vetch, Sand Winter .......................23

Vetch, Spring ......................................23

Velvet Beans ..................................25
BULBS AND SHRUBS

\section{Cannas}

Clematis ........................Back Cover

Cinnamon Vine ................................32

Elephant Ear ............................... Cover

Dahlias ...............................................32

Gladiolus ................................................32

Hedge Plants ..............Back Cover

Hydrangea ....................Back Cover

Ivy ....................................................32

Lily of the Valley ..........................32
Maderia Vine .................................32

Peonies .......................................................32

Privet Hedge .......................................

Spirea ................................................32

Tuberoses ............................................32

MISCELLANEOUS

Bird Seed ........................................13

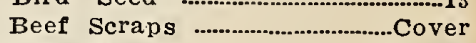

Bone Meal ..................................... Cover

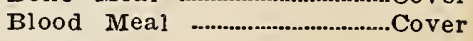

Baskets

10

Bee Supplies .......................................

Chili Supplies .................................14

Egg Crates A.luminum ...................26

Flower Pots .........................................25

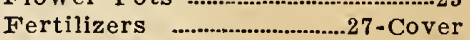

Grass Seeders .................................26

Insecticides …......................................2 7

Incubators ..........................................2 Cover

Leg Bands

Nitragin ...............

Oyster Shells ........................................

Poultry Feed .............................. Cover

Poultry Bone .......................... Cover

Plant Markers

Reed \& Raffia ...................................18

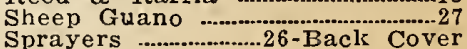




\section{For Sale by \\ SPRINGFIELD SEED C0., Springfield, Mo, Price 50c Postraid- Price 55c \\ Ground Mole Exterminator}

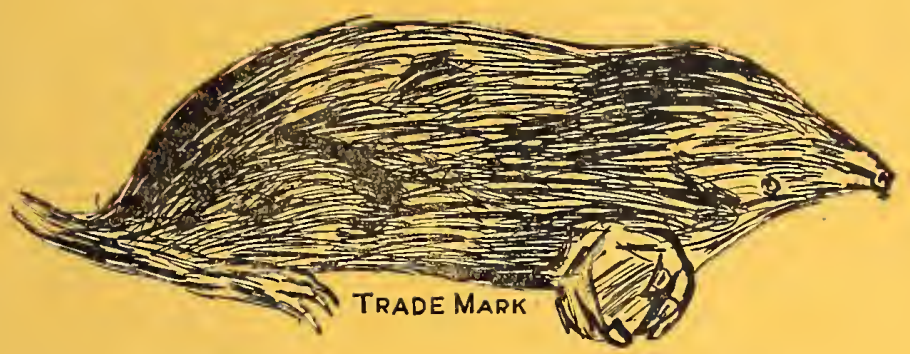

Are you troubled with the "Ground Mole" in your flower beds, gardens or lawn? And have you about exhausted your patience in trying to keep your premises looking nlce and smooth, and in spite of your best efforts there appears some of the most unsightly hills and mounds of earth, thrown up by the "Mole" in its search for food.

The EUREKA GROUND MOLE EXTERMINATOR is made for the purpose of exterminating this troublesome little animal from all such places, including Parks, Golf Courses, Cemeteries and other places of personal and public interest. This EXTERMINATOR is also excellent for use in planting bulbs and pot plants, it serves as a fertilizer and a stimulator for plant life, keeps away the ravages of the cutworms and other destructive worms and insects.

Full directions for use come with each can. It is an inexpensive article to use, and will be found of unequalled value in your Spring planting for both flowers and gardens. 



\section{PARCEL POST}

Undei ruling of the Postoffice Department we can send Seed by Parcel Post up to 70 lbs. in 1st, 2nd and $3 \mathrm{~d}$ zones, and up to $50 \mathrm{lbs}$. to the 8 th zone. This cheap method of delivery places the man who lives 100 miles away as close to market as he who lives in the city. Order Star Brand Seeds and have them at once, as we fill all orders the same day mail is received. See Parcel Post Rates on other side.

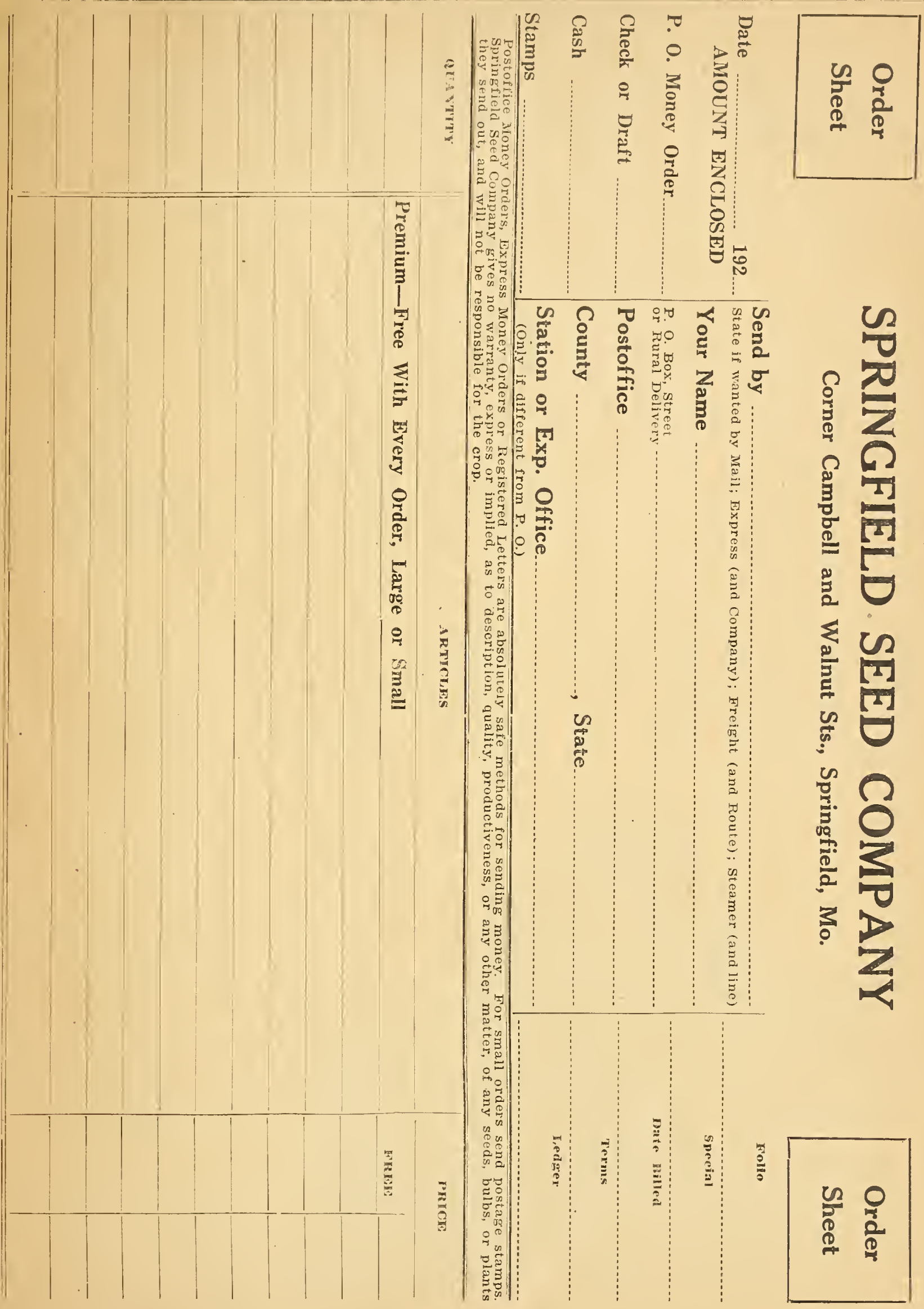


If you want to be first with new potatoes order a few Improved Early 6 Weeks.
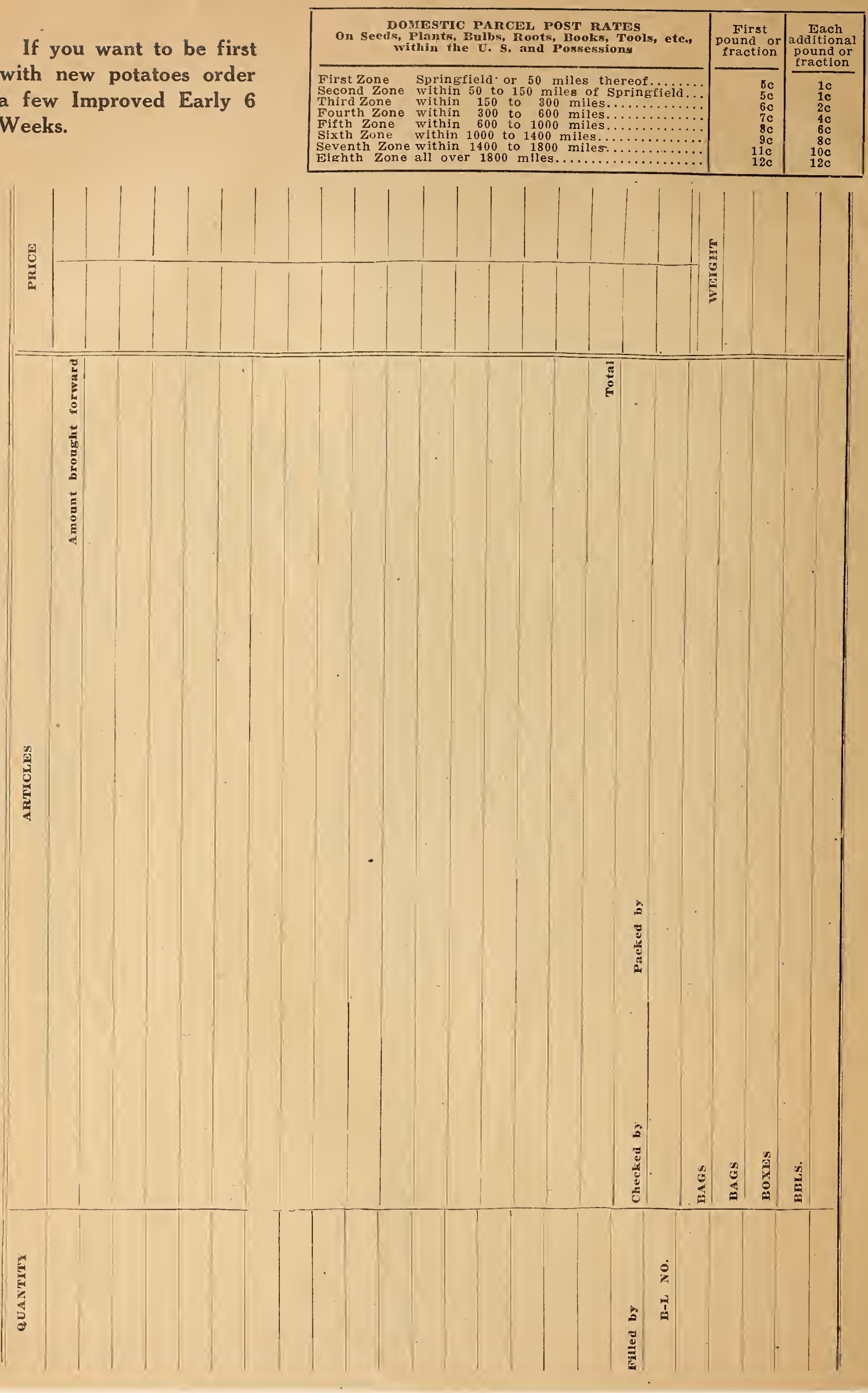
Order Now a few Boxes of our RAINBOW MIXTURE GLADIOLUS BULBS. 1 Doz. Large Size Bulbs to the Box, 50c per Box: add $5 \mathrm{c}$ for Postage.
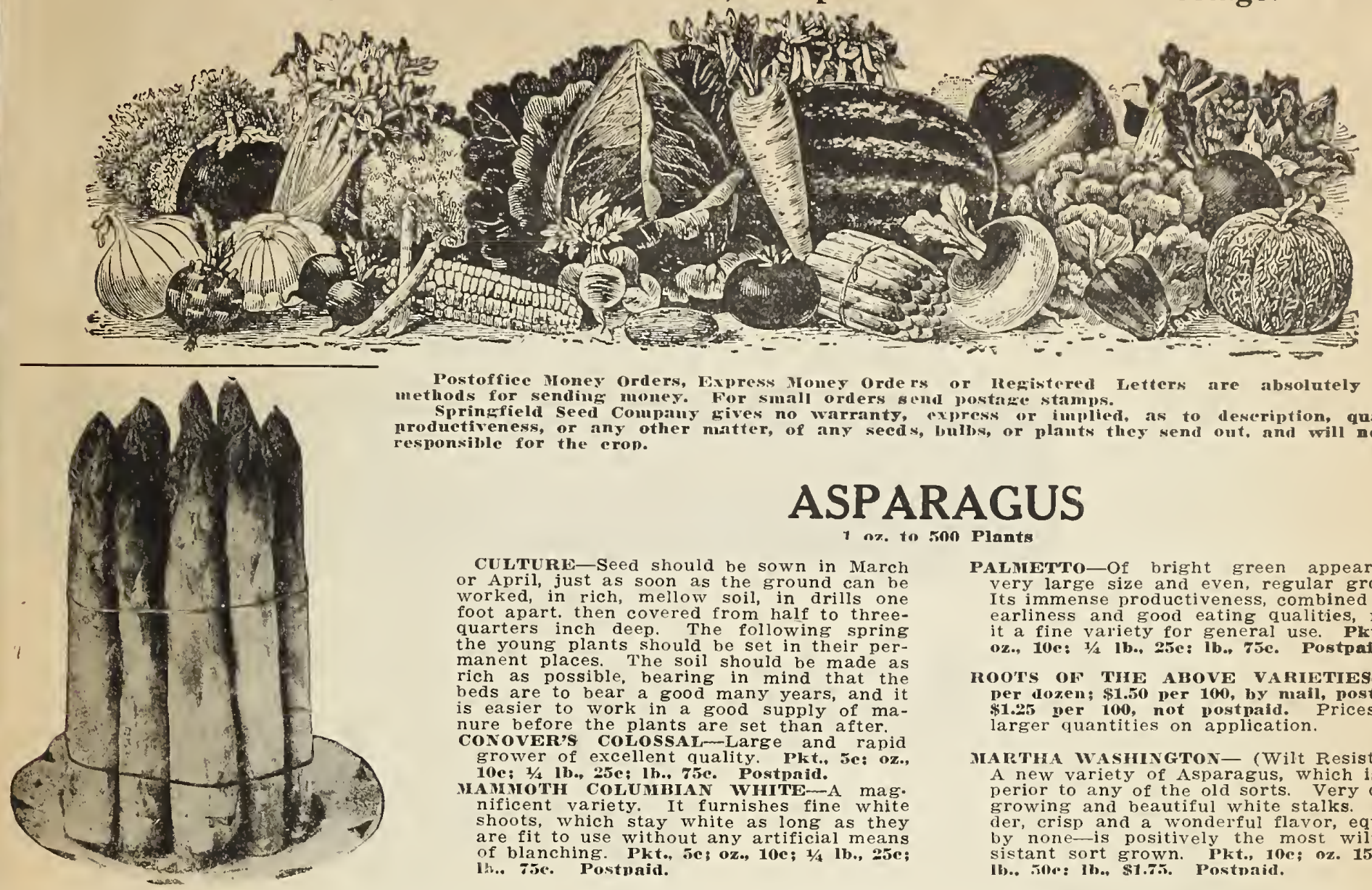

Postoffice Ioney Orders, Lxpress Money orders or IRegistered Letters are absolutely afe

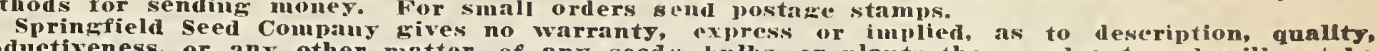
productiveness, or any other matter, of any secds, bulbs, or plants they send out, and will not be
responsible for the crop.

\section{ASPARAGUS}

CULTURe-Seed should be sown in March or April, just as soon as the ground can be worked, in rich, mellow soil, in drills one quarters inch deep. The following spring the young plants should be set in their permanent places. The soil should be made as rich as possible, bearing in mind that the beds are to bear a good many years, and it is easier to work in a good supply of maCoNover's CoLOSSAL-Large and rapid grower of excellent quality. Plkt., 5e: oz., 10e: $1 / 1 / 1 \mathrm{~h}$., 25e: 1h. 75e. Postpaid. MAMMOTH COLUMBIAN WHITE-A mag. nificent variety. It furnishes fine white shoots, which stay white as long as they of blanching. Pkto, se; oz., 10e; 1/4 lb., 25e; lin.. 75e. Postpaid.
PALMETTO-Of bright green appearance, very large size and even, regular growth. Its immense productiveness, combined with earliness and good eating qualities, make

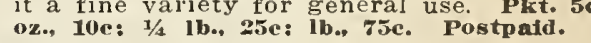

ROO'S OF THE ABOVE VARIETIES-250 per dozen; $\$ 1.50$ per 100 , by mail, postpald. $\$ 1.25$ per 100, not postpald. Prices for MARTHA WASHINGTON- (Wilt Resistant.) A new variety of Asparagus, which is superior to any of the old sorts. Very quick der, crisp and a wonderful flavor, equaled by none-is positively the most wilt resistant sort grown. Pkt., loc:
ili.. ino: 1h., s1.7.5. Postraid.

\section{TABLE BEETS}

$10 x$. to $100 \mathrm{ft}$. Drill SWISS CHARD OR SILVER BEET-Grown
exclusively for its leaves. The midale rib should be forved like balance of the leaf the same as spinach. Pkt., 5c; ox., 10c; 1/1 lb., 25e. Postpaid. THE BANQUET-Dark red Early Turnip Beet. A perfect outdoor variety, preferable to all others for first sowing; may be sown in February or sooner if the soll can be we sown continually as late as July. Handbe sown continually as late as July. Handvome form, good size, and above all of very superior quality and is always preferred at National and Royal banquet Pkt., 10c; oz., 15e; 1/4 lb., 40c. Postpaid. ECLIPSE-A very early, smooth, dark globeshaped Beet, with small top; in earliness and quality it is excelled by none. A good
cropper. We can recommend it highly for market and garden use. Pkt., 5c; oz., 10c 1/4 $1 \mathrm{b...30c.}$ Postpaid.

EDMOND's RLOOD TURNIP-Small top, round and dark red. Pkt., 5e; oz., 10e; $1 / 4$

DE.iviNe'; Postpaid. fine form and flavor. Pkt., 5e; oz., 10c; $1 / 4$ lb.. 30e. Postvaid.

EARLY BLOOD TURNIP-Improved-One of the most popular early sorts. Smooth and dark red. Excellent quality. Pkt., 5e; ox. 10e: 1/1 1b., 25e. Postpaid.

BASTIAN'S HALF LONG-Best for winter use. Dark red flesh, sweet. tender and never woody. Pkt., 5e; oz., 10c; 1/4 1b., 25e. Postpaid.

DETROIT DARK RED-(Turnip Shaped) Valuable because of its uniformity, medium in size, always smooth and free from small roots. The flesh is tender, fine grained, and remains so long after many sorts have become woody. It is admirable for early or late. Pkt., 5e: oz., 10c; 1/4 lb., 35e. Postpaid.

LONG SMOOTH BLOOD-Sweet and tender good variety for fall and winter use. Pkt. retains the earliness of the parent stock and has added thickness, giving it a more able shape. It is the dee most black in color, and is of finer quallty then the Egyptian, being sweeter and desirable sort for small Beets for early market, as it is in presentable market shape quicker than any other sort. It is ry rap crower and can be sown outside as late as July. Pkt., se: oz., 10c; y/ ih.. we. Postuaid.

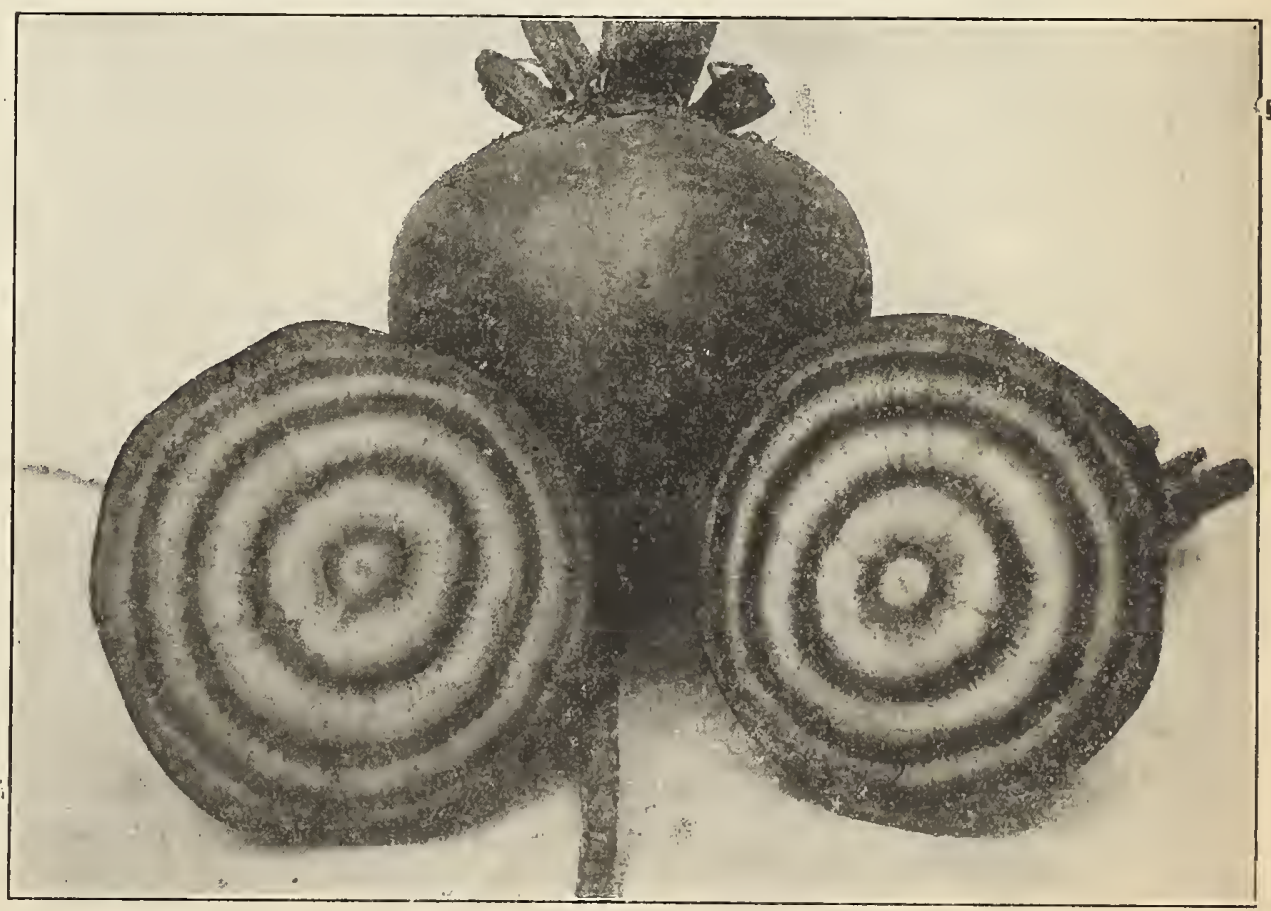




\section{STOCK BEETS or MANGELS}

MAMMOTH GOLDEN GIANT-An improvement on the Long Yellow Mangel, being of considerably greater size, more than half above ground and of a more grayish or rather russet yellow color. Remarkably even in shape rather elongated, of vigorous growth; it has a fine neck and a very smooth skin. Flesh white, firm and sweet, much liked by cattle. In short, a magnificent root, easily lifted from the ground, producing enormous crops. Excellent keeper, yielding 40 to 60 tons per acre. Pkt., 5c; oz., 10c; 1/4 lb., 20c; lb. 60c. Postpaid.
GOLDEN TANKARD-The best Yellow Mangel in cultivation. A distinct and valuable yellow-fleshed variety, which contains a larger percentage of sugar and nutritive matter than any of the redskinned sorts. It is more relished by milk cows and sheep than any other. In shape it is almost cylindrical. It is very easily pulled and is exceedingly hardy. Pkt., 5c; oz., 10c; 1/4 lb., 20c; lb., 60c. Postpaid.

NORBITION GIANT, OR JUMBO RED MANGEL-Stands head above all other varieties of Mangels; unequaled for yielding and feeding qualities. Preferred by many to common Long Reds as its keeping qualities are considered better and it is much larger. Pkt., 5c; oz. 10c; 1/4 lb., 20c; lb., 60c. Postpaid.
YELLOW, OR ORANGE GLOBE-Remarkably smooth in shape, considering the large size attained. Flesh white and a great keeper. Will stand a dry season exceedingly well, hence good for late planting. Pkt., 5c; oz., 10c; 14 lb., 20c; lb., 60c. Postpaid.

MAMMOTH LONG RED-Enormously productive. Yields from 50 to 70 tons to the acre. The roots grow well above ground and are easily dug. Pkt. 5c; oz., 10c; 1/4 lb., 20c; lb., 60c. Postpaid.

RED GLOBE-A large, globular red sort; even a better keeper than the Long Red. It produces fine crops upon shallow soil, which, added to its fine grain and excellent keeping qualities, renders it most desirable. Pkt., 5c; oz., 10c; 1/4 lb., 20c; lb. 60c. Postpaid.

\section{SUGAR BEETS}

VILMORIN'S IMPROVED SUGAR France. It differs France. It differs from th the largest percentage of sugar of any known variety. In size it is medium, yielding from 10 to 16 tons per acre, containing about 18 per cent sugar. Cannot be over-estimated for any purpose. Should be grown in deep soil. paid.

WANZLEBEN-Cultivated largely for the sugar factories, as it usually produces 15 to 20 per cent of sugar. best tested seed. Pl. 25e; lly., oce. Postpaid. SThAR-Famous for its large amount of sugar. Makes 75e. Postmaid.

WHITE FREN CH and uniform in size. Pkt., se; oz., 10e; 1/a llb., 20e; 1b., 706. Postbaid.

\section{BEANS-BUSH LIMA}

FORDHOOK BUSH LIMA-In order to get the best results, plant one foot apart in rows $3 \frac{\pi}{2}$ feet apart. It is an improvement over the well known bush Lima because it is more prolific. It is a stronger grower, more resistant to blight, and is more profitable to grow for the market because the pods remain green.

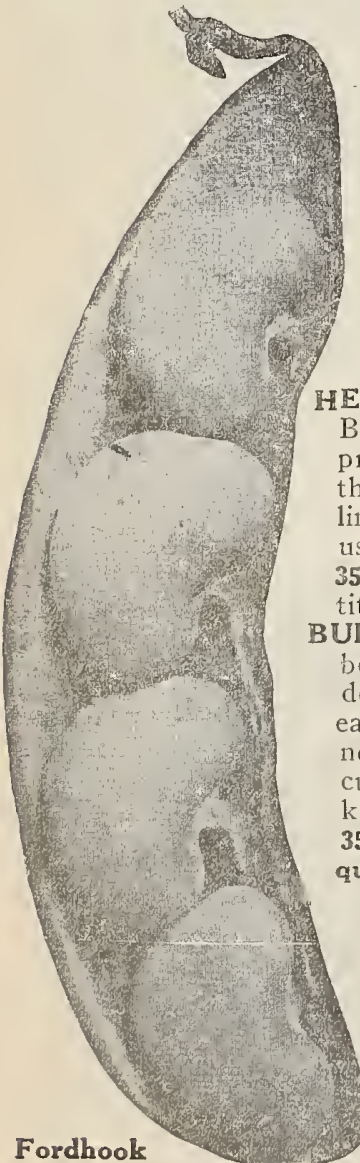

Bush Lim recommend it to our customers for both home and market gardens-for the home garden because of its excellent flavor and productive-
ness; for the market gardener bemanded by the shipper and con-
sumer. Pkt., 10c; lb., $35 \mathrm{c} ; 5$ lbs., $\$ 1.50$. Prepaid.

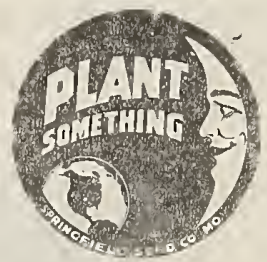
HENDERSON'S BUSH-Small white Lima Bean, of excellent flavor and enormously prolific. It is grown so extensively here that it ranks commercially with commo limas and other commercial varieties. It is 35c; 5 Ibs., \$1.50. Prepaid. Ask for quan-

TUR PEE'S BUSH IMA-This bean has become very popular with the market gardener in all irrigation districts because it is earlier and more easily grown. There are o vines in the way when irrigating and ing. It is ellormously prolific and keeps bearing a long time. Plkt., 10c; lb.,
35c; 5 lbs., \$1.50. Prepaid. Write for quantity price.

\section{BRUSSELS SPROUTS}

The very best winter vegetable, having small knobs or heads along the stem, which may be boiled like cabbage or cooked like cauliflower.

ROSEBERRY - The choicest variety obtainable and highly valued on account markable juicy tender heads. Price: Pkt., 10c; oz., 25c 25c; 1/4 lb. 90c. Postpaid.
WHITE KIDNEY WAX

remium Free with every order-large or small

\section{ARTICHOKE- 1 Oz. 500 Plants}

CULTURE-In February or March sow in hotbed, transplant to the open in May in rows three or four feet apart and two feet apart in the rows. Should give globes the same year. Seed sown in May and transplanted in June has to be Wintered. Tie up leaves, then bank with dirt; will mature the second year.

GIANT GREEN GLOBE-Produces large globular heads, thick succulent scales, the bottom of which is the edible part. Boiled till tender, it makes a delicious dish. Price: Pkt., 10c; 1/2 oz. $25 \mathrm{c}$; oz., $45 \mathrm{c}$; $1 / 4$ lib., $\$ 1.60$. Postpaid.

\section{BROCCOLI- 1 Oz. 5000 Plants}

\section{A Hardy Strain of Cauliflower}

The acreage planted to Broccoli is being enlarged each year; growers find that it endures lower temperatures and more adverse conditions than Cauliflower. It is slow to mature, therefore the eed should be planted during April for a July harvest.

The fact that many growers are securing a satisfactory profit Thould encourage the planting of large acreage.

PURPLE CAPE-Pkt., 10c; oz., 85c; 1/4 lb., \$2.50. Postpaid.

SNOWY WHITE-Pkt., 10c; oz. 85c. Postpaid.

\section{POLE LIMA BEANS}

KING OF THE GARDEN LIMA-A vigorous grower, requiring but two vines to each pole. Begins flowering early, at the bottom of the pole, producing a continuous bloom and fruitage through Pods are large and beans well-formed. Pkt., 10c; lb., 40c; 5 lbs., \$1.75. Postpaid.

LARGE WHITE LIMA-This old well known sort needs no decription. The green beans are very tender and delicious. If allowed to ripen the shelled beans make excellent eating. Pkt., 10c; lb. 35c; 5 lbs., \$1.50. Postpaid.

EXTRA EARLY JERSEY LIMA-A splendid early variety earlier than King of the garden and a good sort to plant for succession. Pkt, 10c; lb., 35c; 5 lbs., \$1.50. Postpaid.

SIEBERT'S EARLY LIMA-An extra early Lima and extremely productive, bearing continuously. The beans are largs and of good quality. Pkt., 10c; lb., 35c; 5 lbs., \$1.50. Postpaid.

\section{YELLOW-POD WAX BEANS, BUNCH}

DAVIS WHITE KIDNEY WAX-Pods long and flat, straight and handsome, free from rust. Pkt., 10c; lb. 35c; 5 lbs., $\$ 1.50$. Postpaid.

IMPROVED BLACK WAX-Very early, round yellow pods. Big favorite everywhere. Pkt., 10c; lb., 35c; 5 lbs., \$1.50. Postpaid. WARDWELL'S KIDNEY WAX-Extra early and productive. Pods long, broad and flat, stringless. Pkt., 10c; lb. 35c; 5 lbs., \$1.50. Postpaid.

DWARF GOLDEN WAX -For years this has been the favorite home garden bean. Long, yellow fleshy and brittle pods which are equally as good dried for winter as in the green state. Pkt., $10 \mathrm{c}$; lb., 35c; 5 lbs., \$1.50. Postpaid.

GERMAN BLACK WAX-Round pods, flavor excellent. Very early. Pkt., 10c; 1b. 35c; 5 lbs., \$1.50. Postpaid.

PENCIL POD BLACK WAX-Pods long, straight and round like pencil. Tender, brittle and absolutely stringless. Pkt., 10c; lb., 35c; 5 lbs., \$1.50. Postpaid. 


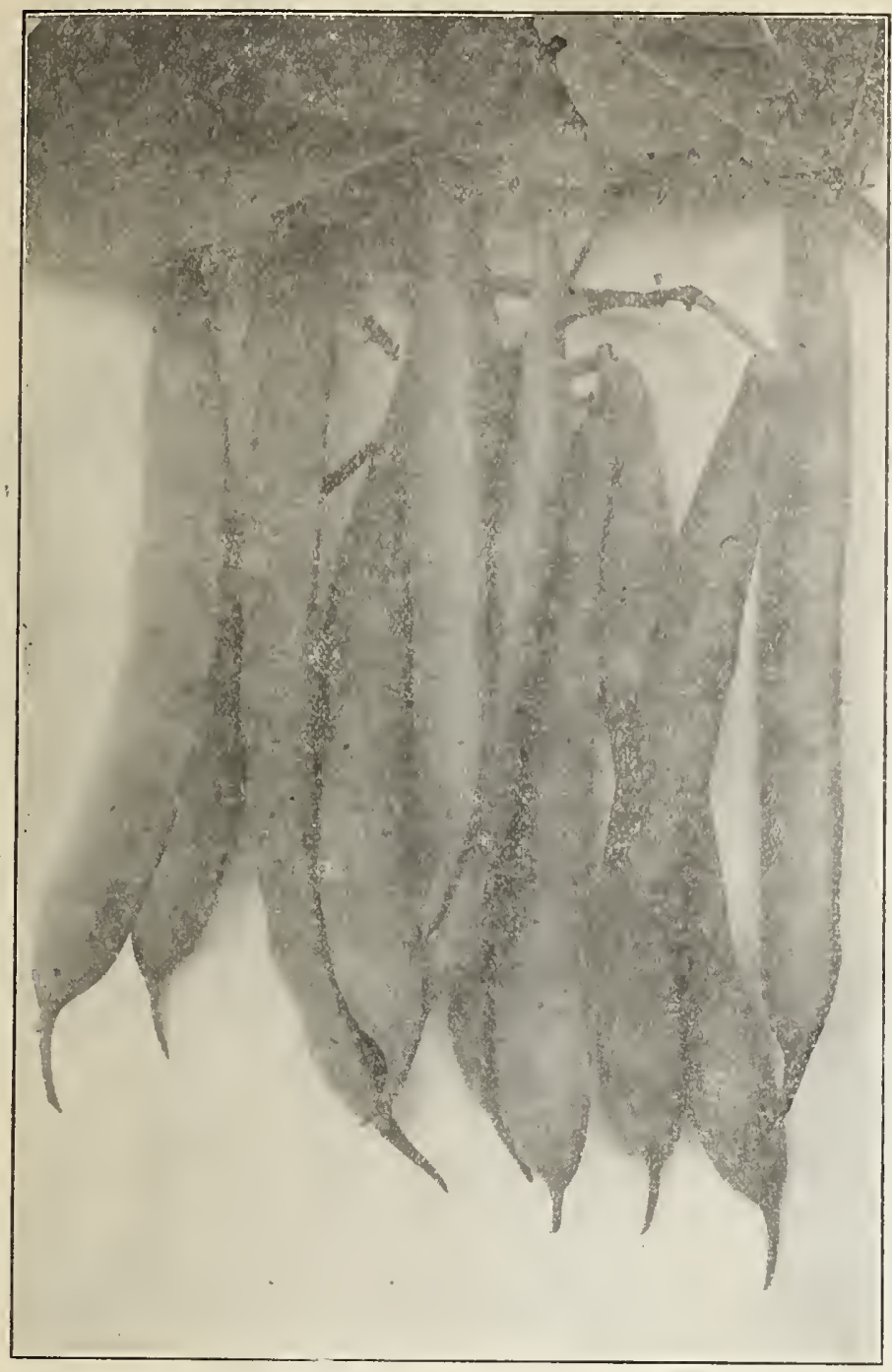

BCRPEIS'S S'TRINGLESS-Green Pod. This wonderful Bean has never been equaled. The best green pod. It is early, hardy and productive, bearing handsome pods which are entirely stringless green color, very round and straight. By repeated plantings, fine pods may be had in constant succession from spring until cut off by heavy frosts in the fall. For either the market or home garden, no other green podded bean is so
10e; lb., 3se: 5 lbs., \$1.50. Postpaid.

\section{POLE OR CORNFIELD BEANS}

1 1b. for 100 Hills, 30 lbs. Per Acre Culture-Pole beans are more sensitive to cold than the bush kinds, and should not be planted before the ground is warm-two or three weeks later than bush beans. Set poles 6 to 8 feet long, 3 to 4 feet apart, in 4 -foot rows and plant five or six beans 2 inches planted in the ech pole. They may also be planted in the cornfield and allowed to run than bush beans. but they are of better quality and bear longer and more profusely. qISSOURI WoNDER-One of the most wonderful Pole Beans grown-is mucl larger than Kentucky Wonder-more prolific and bears until frost. Beautiful dark green pods, filled with large gray striped beans pods, filled with large gray striped beans short, and all orders will be filled in rotation as we receive them. Order early.

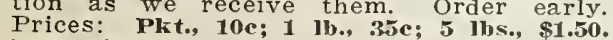
Postpaid.

KENTUCKY WONDER OR OLD HOMESTEAD-We can recommend this as one of the earliest and most satisfactory of all Green Podded Pole Beans, and unsurpassed for using in the green state. It is enormously productive; the long, silver, green pods hanging in great clusters from top to bottom of the pole. While young the pods somewhat resemble the popular old able bean for the market gardener, the pods being so showy and producing so abundantly. Pkt., 10e; 1b., 35e; 5 lbs., \$1.50. Postpaid.

\section{BEANS}

Green Podded Bunch

CLLTIIL-Beans are sensitive to hoth cold and wet, so do not plant till the ground is warm. To have a continuous supply plant clle of August; further. South they may be planted even later. Make
the rows 2 to 3 leet a part, $11_{2}$ to 2 inches deep. Give frequent but shallow cultivation up to Plant in a light loamy suil that wims quickly one pound plants

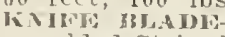
Bean isuired of a snap Bean. This stock was grown by us.

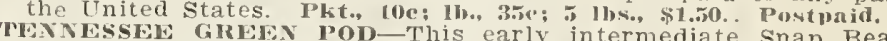
intermediate snap Bean is is the longest podded dwarf sort. The plants are large, somer. It spreading and prolific. The foliage is dark green, with leaves irregular in shads are very long, often six to seven of exceptionally fine flavor. The bht but rather dark green and pressed between seeds. Seeds of medium size oval, flat, yellowishbrown in color. Ilkt., 10e: lb., 35e: 5 lbs.. \$1.50. Postoaid.

GIAT STRINGLESS-One of the finest extra early Beans in cultivation and one that has held its place in spite of many new introductions for which superior qualities were clained. It produces in the sion long; straight, round, deeply saddle-backed pods early growth, brittle, tender and of real good flavor. Pkt., 10e; Ib., RED VAl.ENTINE Postpaid.

Green Pod Bunch (Mean oldest varieties of cold ground when other sorts will not. able beans that we have. Pkt.. 10c: 11., 25e; 5 lbs., \$1.25. Postpaid. cellent fit for use many days after maturity. A most valuable and promising variety. Pkt.. 10m: lb., 35r: ; lbs.. \$1.s0. Postpaid. REWUGEE, OR 10m To $1-$ One of the best snaps for main crop and late or succession plantings. It is enormously productive. The snaps are round-podded, tender and of excellent quality. Later

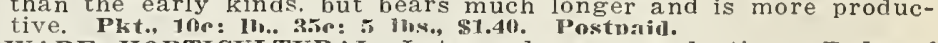
DWARF HORTICULTURA good size, tender and fine flavor. When nearly developed pods are postpaid. With red on yallow skin. Pkt.. 10e; 1h., swe; 5 hos., \$1.50. IPT III Y

10e: lb., 25e; 5 llos., s1.10. Postuaid.

NoHA Wr-Long flat. green pods, very hardy and tender.

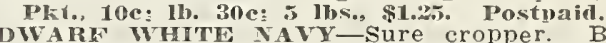

and superior quality. Plet. 10: 1b., oce Beans small, oval, white LONG YLLLOW SIX wEErs - (Green Pods.) Extra early. Long smooth, handsome pods. Very hardy. Pkt., 10c; 13., 25c; 5 1bs, \$1.20. Postpaid.

OU NFUL-As early as Yellow Six Weels, very hatrdy and prolifie: pods are long. broged and meaty, best of flat pod raricties.
plet. 10e; lb., 25e; 5 lbs., $\$ 1.20$. Postyaid.
KENTUCKY WONDER WAX-This excellent new Pole Bean embodies all the good qualities of its green-podded namesake, but has beautiful, transparent yellow pods. It begins to produce its handsome pods when the plants are scarcely higher than the average bush variety. The main points of the Kentucky Wonder Wax are similar to the old Kentucky Wonder, with the following decidedly novel features: The pods are a clear waxy yellow, and more prolific and of much superior quality. The plants ing until late in the season. Pkt., 10c; 1b., ise: 5 lbs., \$1.50. Postnaid.

WHTTE SEEDED KENTUCKY WONDERSimilar to Kentucky Wonder except that the seed is white and pods not quite so green, also valuable as a dry Bean for winter use, Known also as Berger's 5 lbs., \$1.50. Postyaid.

SPECKLED WONDER-Long, dark green pod, extra large, well filled with large gray speckled Beans of fine flavor. Is extra large producer and bears until frost.
Pkt., 10c; 11., 35e; 5 lbs., \$1.50. Postpaid. SOUTHERN PROLIFIC-Small pod and bean. Fine for pickling and canning. One of the best for a Pole Snap Bean. Pkt., 10e; lb.,
WHITE CREASERACK-Extremely early, very productive. Pods are borne in clusters from four to six; broad, thick, solidly fleshy and stringless. Well adapted for shipping to distant markets. Pkt., 10c 1b., 35e: 5 lbs., \$1.50. Postpaid.

CUT SHORT, OR CORNFIELD-Green beans resemble those of Bush Valentine. Dry beans, red speckled. Pkt.. 10c: lh., 30c; 5 lbs., \$1.40. Postpaid.

HORTICULTURAL POLE BEAT-The mammoth pods are beautifully striped and splashed with brilliant carmine; very showy and attractive, and the immense beans are of the best quality. Pkt., 10c: lb., 30c: 5 los., $\$ 1.40$. Postpaid.

WHITE DUTCH CASE KVIFE-Fields an immence crop of handsome flat white beans of excellent flavor. Cooks easily. Pkt., 10c; 1b., 35e; 5 lbs., $\$ 1.50$. Postpaid. MAMMOTH CARMINE PODDED-Probably the largest bean grown, except some of the Limas. It is entirely distinct from all others. Pkt., 10c; 1l.., 35e; 5 lbs., \$1.50. Postpaid.

LAZY WIFE-The pods are of a medium dark green color and grow from 5 to 7 inches in length. They are broad, thick and very fleshy, and are entirely stringpaid. 


\section{CABBAGE $\begin{gathered}1, \text { Oz. For } \\ 3,000 \text { Plants }\end{gathered}$}

CULTURE-The ground must be highly manured, deeply dug or plowed, and thoroughly worked to insure good heads. A heavy, moist and fresh loam is the most suitable. The in open glound. Plant out 18 inches by 2 feet apart. The plants ares are usually sown by the last of May and the apart in the rows. One ounce will produce 5,000 plants. $1 / 4$

\section{EARLY SORTS-POINTED HEADS}

EAKLY JERSEY WAIKEFIELD-(True American.) Very early; a remarkably sure header of good quality; one of the most profitable sort. Plkt., 10c; oz., 20e; 1/4 lb., 50c. Postpaid. EARLY WINNINGSTAT-Extra early. Pointed heads. Best for early use: Pkt., 10e: oz., 20e; 1/4 1b., 50c. Postpaid.

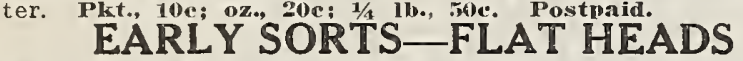

EARLY DWARF FLAT DUTCH-Maturing with early summer our Early Dwarf Flat Dutch is a most valuable and popula second early variety. It produces large, round, heads, which variet. 10e; oz., 20e; 1/4 10., 50c. Postpaid. HARLY DIRUMHEAD-Very popular in the South. Makes splendid second early sure-heading cabbage. Heads large, flattened on the top, solid, crisp and tender. Pkt., 10c; oz. 20c: 1/4 lb., 50c. Postpaid.

ALL SEASONS-Extra select for both early and late; flat head. Pkt., 10c; oz., 25e; $1 / 4$ 1b., 75e. Postpaid.

HENDERSON'S EARLY SUMMER-A splendid sort coming in just after the Wakefield. Makes large, fine, round heads. Pkt., 10c; oz., 25c; 1/4 1b., 75e. Postpaid.

HENDERSON'S SUCCESSION-Very popular summer Cabbage about ten days later than the Early summer. The heads grow larger; are full and solid, and keep excellently. Pkt., 10c; ox.4 :5e; 1/4 lib., 75e. Postpaid.

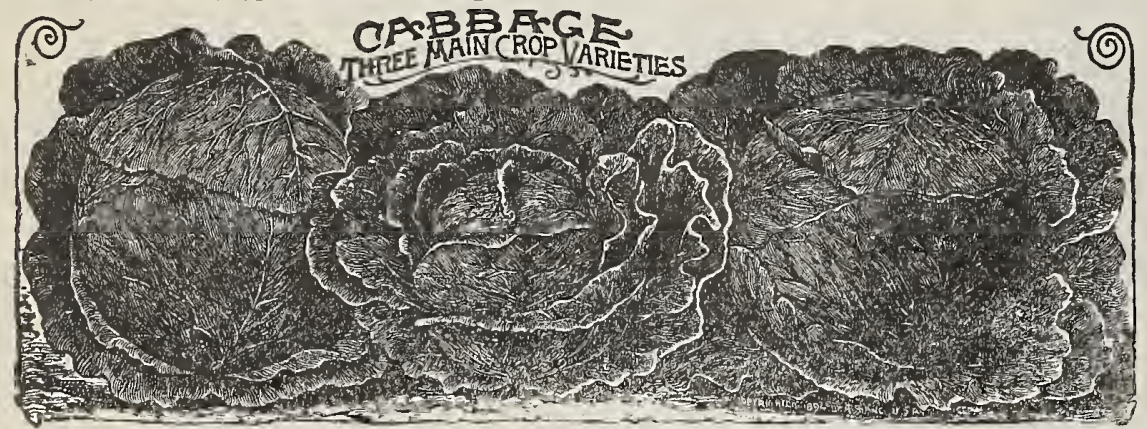

Late Flat Dutch

Henderson's Eearly Summer
Copenlugen

\begin{tabular}{|l|}
\hline See \\
Spraying \\
Material \\
Page 27 \\
for \\
Bugs and \\
Cabbage \\
Worms \\
\hline
\end{tabular}

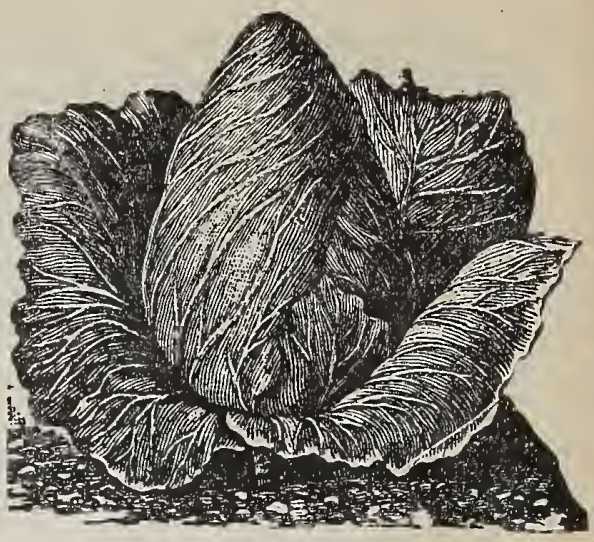

\section{COPENHAGEN MARKET}

Medium Eariy

-This is without question one of the finest medium early varieties. Large, round, solid heads. Very few outer leaves. Tender, crisp and brittie. Jersey Wakefield. Pkt., 10c; ox., 30e; 1/4 lib." 75c. Postgaid.

\section{BIG CHARLESTON}

To those who have grown this wonderful Cabbage we need not print a description. But for the benefit of those who have not tried it we wish to say that it is the most wonderful cabbage ever grown. A beautiful dark green, outer leaves blending to a light green center covering. The head is solid, crisp and tender and attaining a weight of 12 to 15 pounds. Has a flavor all its own, and is most delicious made into kraut, slaw or cooked. Pkt., 10c; oz., 20c; $1 / 4$ ib., soc.

We can also furnish Frost Proof plants of this cabbage. 15e dozen. Postyaid.

FROST PROOF PLANTS, for which the demand is rowing greater each season. If you want extra early cabbage order a few dozen, See page 14.

CABBAGE PLANTS of all varieties for early or late planting.

Write for our complete plant list, or see page 14 .

\section{LATE VARIETIES}

LATE DRUMHEAD-This variety is too well known for long description. Pkt., 10e: ox.. 20c: 1/4 lb., 50c. Postpaid.

LARGE LATE FLAT DUTCH-A good strain of this popular winter Cabbage. Makes good, large, solid, flat heads that keep well into the winter. Pkt., 10c; oz., 20c; $1 / 41$ b., 50c. Postpaid.

gT. LOLIS LATE MARKET-One of the most popular sorts Pkt., 10c: oz., 25e; 1/4 1b., 75e. Postpaid.

gURE HEAD-Large, flat head of fine flavor; a sure header; fine for home gardens. Pkt., 10c; oz., 20c; 1/4 1b., 50c. Postpaid.

MAMMOTH HED ROCK-This is by far the largest and surest heading red Cabbage ever introduced. The plants are large with numerous spreading leaves. The head is large, round, very solid, and of a deep red color. Ninety-eight per cent of the plants will form extra fine heads. Pkt., 10e: or., 40c; 1/4 1b., \$1.00. Postpaid.

DANISH BALLHBAD-Or Hollander. The heaviest Cabbage for its size we have ever grown; exceedingly solid and hard; handsome; very hardy, a sure header, a good seller and one of the finest of keepers, making it particularly desirable for shipping long distances. Our stock is grown by the most careful and experienced grower in Denmark, where the finest Ballhead Cabbage in the world is grown, and is imported direct. Ours is the true short-stemmed Ballhead. Pkt., 10e; oz., 40c: $1 / 4$ 1b., \$1.00. Postpatid.

AMERICAN DRUMHEAN SAVOY-(Wirsing.) The leading variety of all Savoys. Valuable for private garden. Sweeter than other Cabbage, especially when touched by a slight

GLORY OF ENKHUIZEN-One of the best second early varieties. Earlier than All Seasons, very solid, nearly round, approaching closely in this respect the new Copenhagen Market, as it does also the hardiness and solidity of that variety. it has few outer leaves and can be set closer than other varieties. It is an excellent variety to follow coper.
Market. Pkt., 15c; oz., 3.. 1/4 1b., \$1.25. Postpaid.

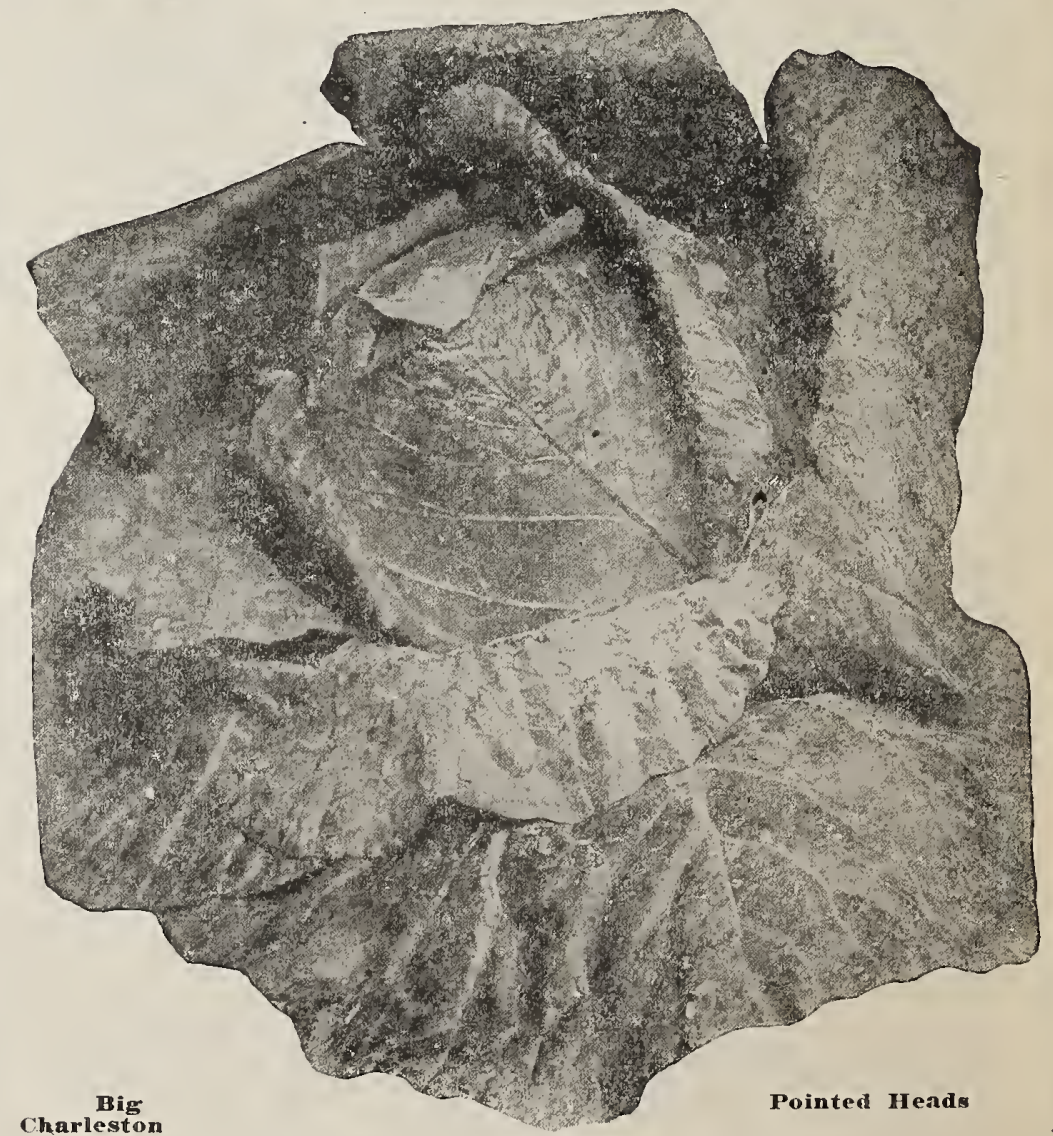




\section{CARROTS}

y/z Oz. to 100 Ft. Drill

CULTURE-Deeply tilled soil of a light sandy loam is the most suitable for Carrots. Land that has been manured heavily the year pervious is the best. Cover the seed about one-hale inch in depth, and press the soil firmly over the seed wrin the pays as the ground can bem three seed will sow an

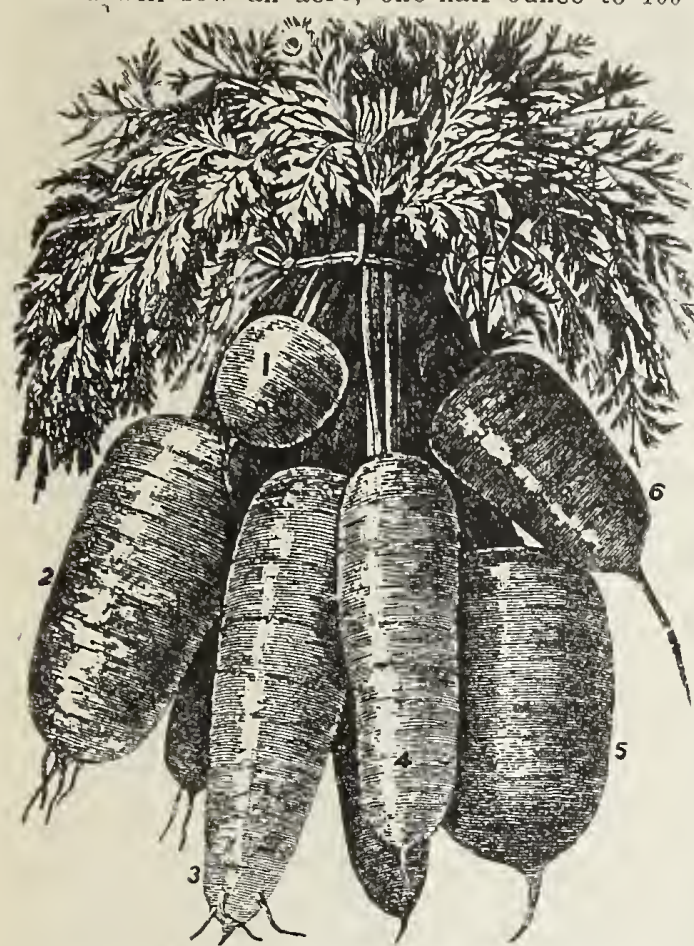

OXMLART OR GU ERANDE The French of the most valuable varietics either use or for the market. It is an inbetween the hall long and type, attainlag a diameinches at the very productive. Pkt., 5e; lb., 35e. Postpaid.

F IR E N C H Forcing -

able sort and

one of the

Roots red-

dish orange

solid and ten-

der wh e $\mathrm{n}$

should be

soon as large

ise. Plkt. 5e: ox. 10e: $1 / 4$ 1b., 25e. PostBelgian; 5 , Half Long; 6, Stump Rooted.
Belart

CHANTENAY - A nice smooth Carrot of perfect and uniform shape. A heavy yielder, a fine table quality, 5 to 6 inches long and easily dug. The flesh is of a deep yellow color, tender and of excellent flavor. Pkt., 5e; oz., 10e; 1/4 1b., 25c. Postpaid. DANVERS HALF LONG-Admirable in color, fixed in habit, a wonderful producer, the best of all for the stock breeder, and valuable to the market gardener. With this variety the planters secure the largest return to the acre, with the least paid.

IMPROVED LONG ORANGE-The old standby for both stock feeding and table use, either summer or winter. Fed to milch cows, it increased the flow of rich milk and gives to

LARGE WHITE BELGIAN-Grows one-third out of the ground. Root pure white, green above the ground, and has a small top. It will grow to a very large size on rich soill, and is very easily gathered. Flesh rather coarse and used exclusively for stock

\begin{abstract}
20c. Post
\end{abstract}

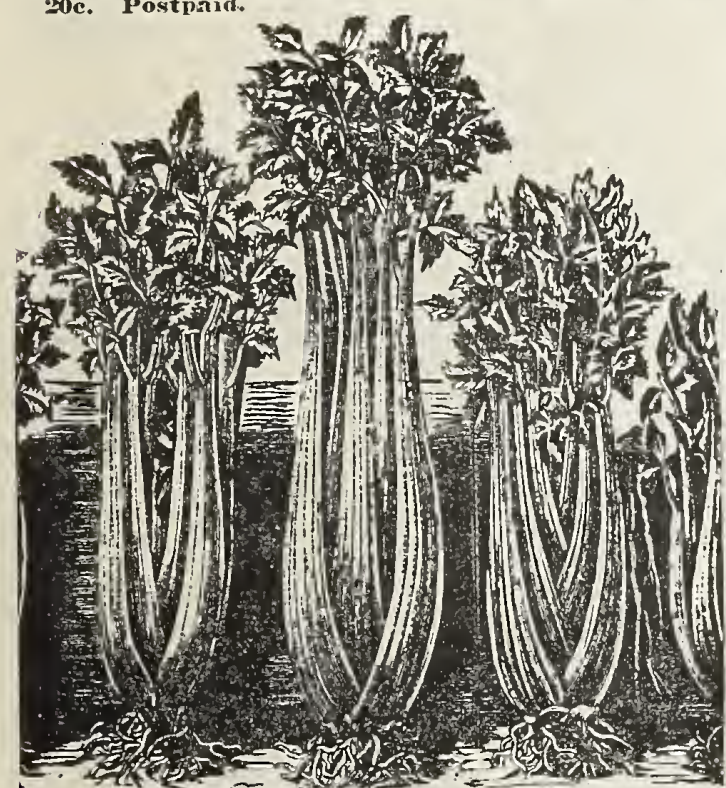

CULTURE-Celery seed is slow to gerwinly; cover lightly. Keep constantly moist. Count on about 6,000 plants per ounce of seed or $1 / 4$ pound per acre. When should be clipped at the top to favor stocky growth, or else transplanted. Celwithout trenches, in rows 3 to 5 feet apart. For home use Celery is often ithout trenching, and banked for win-

GOLDEN SELF BLANCHING-This is a growth, and has straight and vigorous stalks. The ribs are perfectly solid crisp and brittle. Its delicate flavor is surpassed by no other variety, and
moreover it has the decided merit of moing self-blanching to a very remarkable degree. Pkt., 10c; oz., 40c; $1 / 4 \mathbf{1 b}$ \$1.25. Postpaid.

GIANT PASCAL-This is a green leaved variety. It bleaches very quickly after white color, very solid and crisp, and of a sweet flavor which is not equalled by any other variety. The stalks grow a large bunch. Under high cultivation this variety will give best satisfaction

\section{CAUULIFLOWER}

planting of Cauliflower is easy and is mucl the same as that of 年

SNoWfarc-Best variety for famlly and home garden. Market

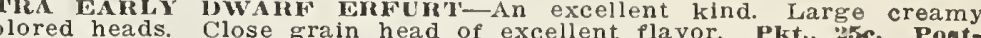
CHIVES

very strong onion flavor and ls one of the arliest all-year plants to come up. Multiplies very fast. Lives forever. CHICORY

FFEE-Sown in drills, the roots becomes well developed. When they are dried, roasted or ground, they become the CELERIAC

he roots, which are turnip-shaped, very smooth,

LARGE SMOOTH PRAGUE-This is unquestionably the largest and best t.. 5e; oz, 25c; 1/4 1b, 75e, Postpaid.

\section{FinNGSE (GBBAG - बines} SHANTUNG

Improved Chinese Cabbage. The market appearance of this cabbage in quantity the past two years has created a widespread dethe seed. It is very easily grown and does well in nearly all parts or the cabbage. planting in July (turnip planting time), as early planting run quickly to se The sown in drills 16 to 20 in three times. The full grown plant somewhat resembles a Cos Lettuce in appearance. It has mild flavor and may be eaten raw or as soned with butter is especially delectable. MOSTON MARKET-The most popular variety in the market of Boston. It forms a cluster of heads instead of single one
and is exceptionally tender and crisp. The best variety for light solls. Pkt. Fe: oz.. 30c: 1/a lb., \$1.00. Postpald. WHITE PLUME-This Celery is valued beause the stalks and portions of the inner leaves and heart are white; by simply tying up the stalks and drawing up tal, tender, crisp, of good flavor and very early. Pkt., sc; oz., 35e; 1/4 lb. DWART GOLDEN HEART-Very popular and distinct variety. In habit of growth blanched the heart, which is large and waxy golden yellow. It is reeps well during the winter. Pkt., 5c;

\section{COLLARDS}

A plant bearing a large mass of leaves of cabbage and the stavor. It is a species bears a e. and the flavor is the same. It is used especially in the South for cabbage greens. Young plants may bestarted in boxes in early spring, and the young room for each plant. Set $14 \times 18$ inches. TRUE GEORGIA-Grows from 4 to 5 feet high and forms a very large, loose head. Leaves are tinged with purple. Pl. 


\section{CUCUMBERS}

\section{Or. to 75 Hills}

CIT,TTIR F:

Cucumbers flourish best in a rich, Can when danger warm, sandy loam. Sow when danger each way. As the young plants have many enemies sow thickly deep, and then thin out finally four plants to the hill. Use two to three pounds to the Cucumbers by earing. Leave none to ripen, full crop.

ARLINGTON WHITE SPINE CUCUNBERThis is the most profitable cucumber for truckers, It is the easiest, most shapely, green color throughout its entire length, very straight and symmetrical. The strain needs no recommendation where known and a trial order will convince you of the 1/4 lib. 2uc. Postpale.

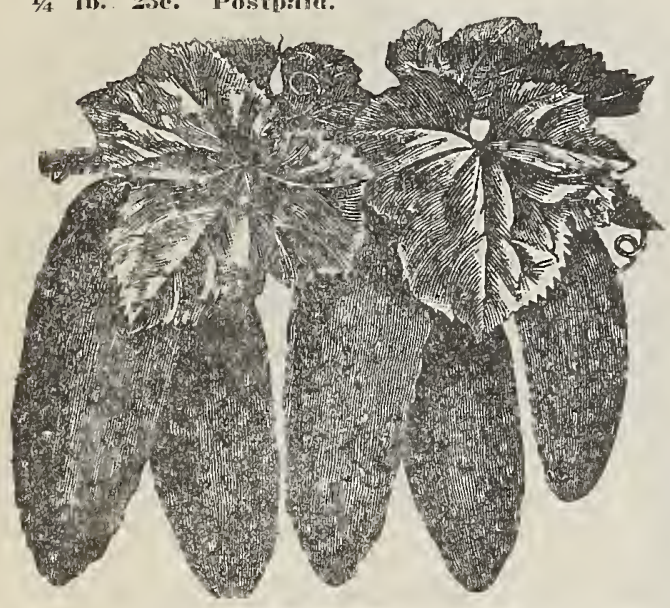

For Bugs, Beetles and Worms on Cucumbers Use Gardite Slug Shot or Checkers. 25c Per Package. 'See page 27.

\section{EGG PLANT}

CULTLRE-Sow in hot beds very early in the spring; thin them out as soon as big enough to be handled to 3 or 4 inches each way, and transplant to 2 or 3 feet apart in very rich warm ground. Do not plant them oultside till nights are real warm, as the least frost will, if it does not kill them, check the growth, and it will
take 2 or 3 weeks before they get over it. Hoe often and hill up gradually till they bloom. One ounce to 1,000 plants.

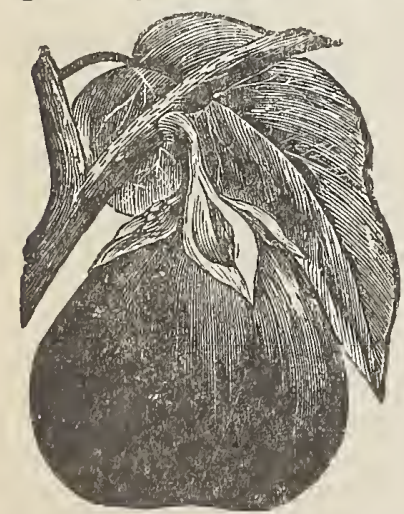

GICTK GIANT-This splendid va riety we have obtained by year trast careful selection and ex for such a large sort, a suri cropper, and entirely spineless and plants are large, vigorou. color and shape: very large usually 6 to 8 inches in diameter but sometimes specimens ar grown measuring 10 inches. Ski and glossy. Flesh white, of suPkt., 15e; 1/2 oz., 40e; oz., 750 Postpaid. IV YORK IMPROVED-V e r 10e; 1/2 oz., 30e; oz., 50e. Postpaid BLACK BEAUTY-The best earl market variety. Also the bes for home use. It is fully ten days earlier than the New. Yor Improved, very attractive in appearance and entirely spineless. The fruits set freely and develor oz.. 3for: oz. sole. Posthaid.

GARLY LONG PURPLE-This is the earliest variety; very hardy and productive; fruit long and of superior quality. Pkt., 5e; $1 / 2$
STEVENS, PERFECT-It is an early, prolific, and continuous producer of uniformly large and symmetrical fruits of an intensely rich; deep green color, shading perfectly to the ends. It runs so close to type that there is practically no mishapen fruit or culls. Ideal for slicingfresh, sparkling white and refreshing. Makes a delightful plate on the table and the flavor is new to cucumbers. Vines are vigorous, mildew-proof, maintaining their luxuriance and bearing from the earliest to latest season. We pronounce either home or market gardeners. Pkt., 5e; 0z. 15e; 1/4 1b., 40c. Postpaid. EARLY GREEN Ch $\mathbf{U}$ \& $\mathbb{T} \mathbb{R}-$ Short and prick-
ly; bearing in clusters; prolific: fine for bot-
tling. Pkt., 5e; tling. Pkt., 5e; 25c. Postpaid. QARLYY FRAMEPkt, 5e; oz., 10e; $1 / 4$ lb., "5e. Postpaid.

JAPANESE CLIMBIN Gr-A most desirable and attractive cucumber for growing on poles or trellis, taking but little room in the garden. Comes into bearing quickly and sets its fruit constantly throughout the season. The fruit is of extra fine quality, and of a dark green color. Plkt., 5e; oz., 15e; 1/4 lb., 40e. Postpaid.

IMPROVED LONG GREEN-Unquestionably this is the most popular general purpose cucumber. When matured is 9 to 12 inches long, very solid and crisp, retains its dark green color until nearly ripe. One of the best for small pickling if pickled properly.
Pkt., 5e; oz., 10c; 1/4 lb., 25e. Postpaid.

GHERKIN-A very small oval sort, grown exclusively for pickles. Prolific to a extraordinary degree. Seeds are slow to ger-
minate. Plkt., 5e; oz., 15c: 1/4 lb. 50c. Postpiaid.

BOSTON OR JERSEY PICKLING-a favorite eastern sort of fine quality, medium ength; reliable variety for pickling and

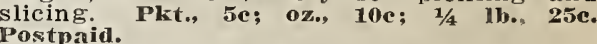

GXTRA EARLY WHITE SPINE-Pkt., 5e; oz., 10c; 1/4 1b., 25c. Postpaid.

DAVIS PERFECT-Pkt., ac; oz., 10c; 1/4 $1 \mathrm{~b}$. Ac. Postpaid. EARLY GRELN PROLIFIC-Pkt., 5e; oz.,
10c; $1 / 4$ lb., 25c. Postpaid.

\section{ENDIVE}

MAMMOTH . GREEN . CURLED-A beautiful and valuable variety. Superior to any ther. Grows 15 to 20 inches in diameter. Leaves are very crisp, tufty and full. Extremely hardy, equally suitable for spring, summer or autumn planting. Pkt., 5e; oz., 15e. Postpaid.

QVERWHITE CURLED-Midrib y e $110 \mathrm{w}$, leaves almost white; large size. A very
sightly variety. Pkt., 5e; oz, 15e. Postpaid.

\section{GARLIC-FOR SEED}

Thrives best in light, well-enriched soil. Bulbs should be planted in the fall 6 to 8 inches apart. Cultivate and store the same as onions. Much valued for flavor

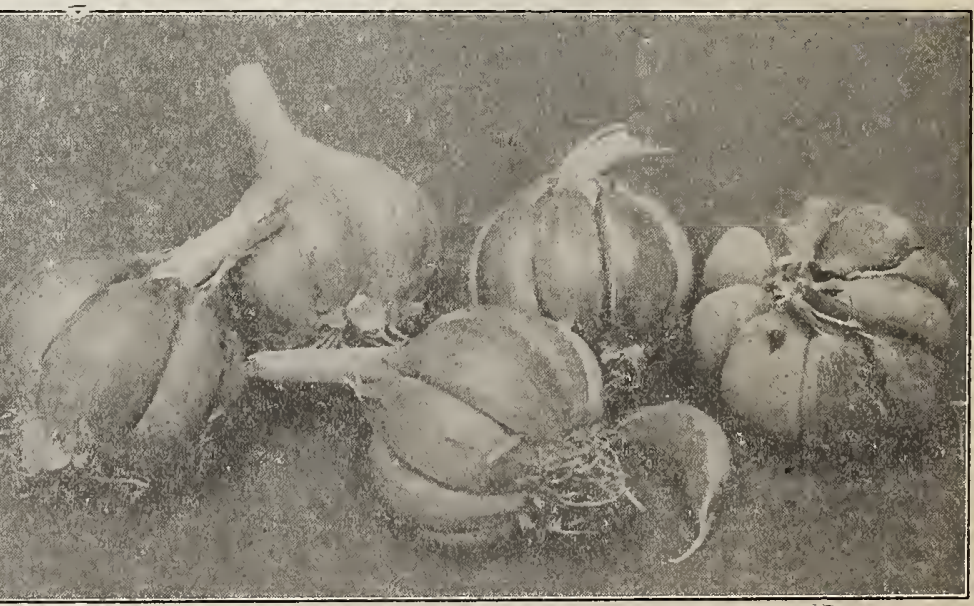




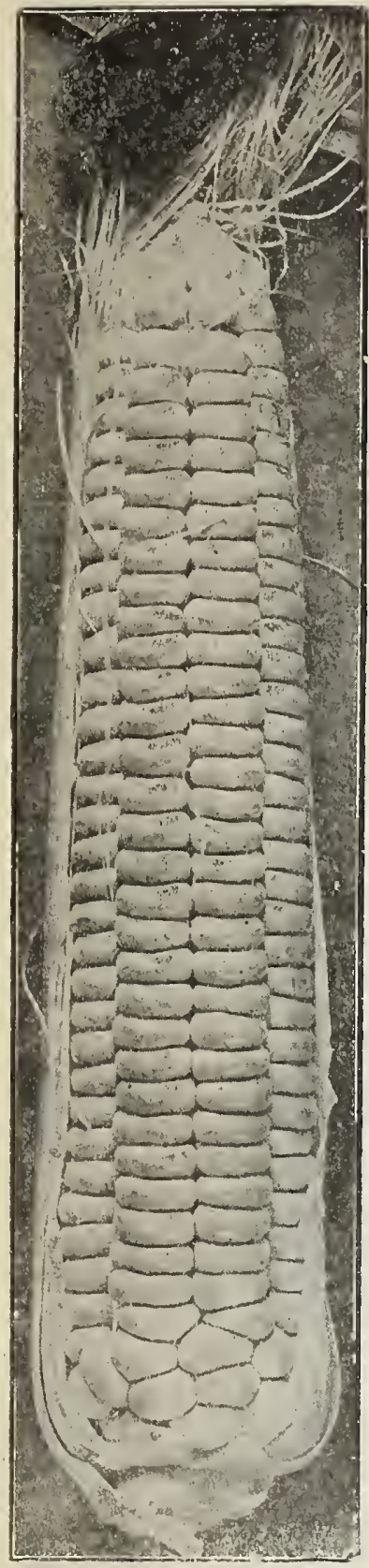

STOWELL'S EVERGREEN

-(Plant for "Late," Sweet variety, both for home use and market, and is the general favorite. The ears are of a large size, grains deep, exceptionally tender and sugary, and have'the advantage of remaining longer in the green state than any other. Pkt., 10c; lb., 25c; 5 lbs., \$1.10. Postpaid

SHAKER EARLY-Is ready for market about the same time as Early Minnesota, but has much larger ears, which come two to the stalk and are well-filled with 14 rows of broad, flat grains of excellent flavor and sweetness. Is a great favorite with market gardeners on account of its size and appearance. Pkt., 10c; lb., 25c; 5 lbs., \$1.10. Postpaid.

\section{EARLY MAMMOTH-This} sort is very largely grown in Greene County. The ears are long, very large, and well filled with 10 to 14 rows. The variety is medium early and of good quality. Plst., 10c; lb., 25c; 5 lbs., \$1.10. Postpaid.

EARLY SWEET OR SUGAR - The ears of this second early table corn are very long, about nine inches, slender, eight rowed, and the grain is white, tender and sugary. The stalks are about six feet high, hardy and productive. Our stock is distinct and true and not such a mixture of all sorts of early sweet or sugar corn as has been often offered under this name. Pkt., 10c; lb., 25c; 5 lbs., \$1.10. Postpaid.

KENDEL'S EARLY GIANT-Remarkably large in ear for a second early sort and extensively grown in some localities for the market. The stalks are about five and one-half feet high. The ears are about eight to nine inches long, twelve rowed. The grain is white, rather broad and shallow; and the quality very good. Pkt., 15c; lb, 25c; 5 los., \$1.10. Postpaid.
SWEET CORN N

CULTURE-Sweet Corn is tender and rots easily in cold or wet ground. It should not be planted until the soil is warm and the leaves on the trees
are well out. Hills should be $2^{2} / 2$ to $3 \mathrm{ft}$. apart each way, dropping 5 to 6 grains in each, thinning out afterwards to the desired number of stalks. A continuous supply may be had by planting early, medium and late varieties at one time or by planting at intervals of 15 days. One $1 / 4$ pound plants 100 hills, about 12 pounds per acre.

GOLDEN BANTAM-The sweetest of sweet corn. Words cannot describe or convey to the mind this delicious corn. Beautiful golden color well-filled yellow kernels of flavor found in no other corn; is very hardy and will stand earlier planting than most other kinds. Dwarf growing stalks and usually has two and sometimes three ears to the stalk. For fancy table use it is surpassed by no other corn. Pkt., 10c; lb., 25c; 5 lbs., \$1.10. Postpaid.

\section{COUNTRY GENTLEMAN - (For}

Main Crop.) The most delicious Sweet Corn grown. Plump, pearly white, milky kernels, fairly melting in the mouth. Retaining its delicate tenderness even when a little old. Very productive, each stalk yielding 3 and often 4 ears; even 6 ears to a stalk occasionally. Country Gentleman is the finest of all Sweet Corn for the private table. The arrangement of the kernels on the cob in dicate high quality. The moment the teeth sink into this luscious, milky, tender corn you will become a convert to it for it will delight the most fastidious epicure. It retains its delicate tenderness and flavor even when a little old, as the ears are enclosed in a heavy husk which tends to keep the ear in "the milk" for several days longer than other corns. The ears average 8 to 9 inches in length, cob small, and plump, pearly-white kernels of great depth fill the ear from end to end. But the great merit of the "Country Gentleman" corn is its delicious quality; it is, without doubt, the sweetest and most tender of any sweet Corn. Pkt, 10c; lb., 25c; 5 lbs., \$1.10. Postpaid.

EXTRA EARLY ADAMS-Same size, type and style as Early Adams. Hardiest and earliest corn. It is not a Sugar Corn, but is grown for early use. Ears short, kernels very white. Like Early Adams it is hardy and can be planted early. Pltt., 10c; lb., 25c; 5 lbs., $\$ 1.00$. Postpaid.

BLACK MEXICAN-The grains when matured are blueblack, and when in edible state are cream color. Tender and of excellent quality. Pkt., 10c; lb. 25c; 5 lbs., \$1.10. Postpaid.

LATE MAMMOTH-The latest but the Largest of all the Sweet Corns. The ears are of mammoth size, covered from tip to butt with large, broad grains of the most delicious flavor; sweet and tender. Plst., 10c; lb., 25c; 5 lbs., \$1.10. Postpaid.

EARLY MINNESOTA-This deservedly popular variety is one of the best second early sorts for the market and the home garden. The stalks are about six feet high, bearing one or two ears well covered with husks. The ears are about eight inches long, eight rowed; kernels very broad, white sweet and tender, not shrinking much in drying. By careful selection we have developed a stock of this standard variety which is remarkably uniform and in which all the good qualities that have made this sort so desirable are intensified. Pkt., 10c; lb., 25c; 5 lbs., \$1.10. Postpaid.

\section{ORIENTAL SEED}

Each one a True and Tried Variety-that you can depend upon. BEANS-Yard long, pods grow $3 \mathrm{ft}$. long, fine flavor, cook green. Pkt., 10c. Postpaid. EGG PLANT-Chinese, grows 15 to 25 inches long, excellent flavor. Pkt. 25c. Postpaid CUCUMBER-China, grows about 20 inches long, 2 inches in diameter, deep green, flesh white crisp and fine flavor. Pkt., 10c. Postpaid. PE-TSAI-Chinese cabbage (Shantung). See complete description page 5. 
Lettuce s e ed

$t h$ is season is

extrem e ly

scarce and

thos e using

l a r g e lots should or d e r early.

GKA IUAPIDS-A forcing variety of su-

perior quality and beautiful appearance, crisp and tender without wilting when ex-

ing lettuce. It is also a desirable variety

for sowing in open ground. Plet. 5e; oz.

for sowing in open ground. 1 h. fige. Postpaid.

EARLY CURLED SIMPSON-A good forcing sort. White seeded. Resembles Black Seeded Simpson. Early, and an old favo-
rite with all. Pkt., 5e; oz., 15e; $1 / 4$ lb., $60 c$. Postpaid.

ICEBERG-Hardiest heading sort and excellent for home or market.
15c: $1 / 4$ lh. 50c. Postpaid.

DENVER MARKET-Used either for forcing or open ground. An early variety, formlight green color, curled somewhat like Savoy Cabbage, and always crisp and
tender. Pkt., 5e; oz., 15e; 1/4 1b., 50e. Post-

prizi HEAD-Very tender leaves of dark reddish-brown color, variegated with dark green. Heads large and of good flavor. We sell more of this than any other brown-

5e; oz., 15e; 1/4 lb., 5oc. Postpaid.
NEW TRIANoN Cos-The finest of all the

Cos sorts. Leaves when bleached are stiff

like Celery stalks.

BIG BOSTON - I m p roved

strain, crisp, tender, sweet

big, compact, and very early.

The best lettuce you ever

saw, grows almost as large as cabbage For either spring, summer or fall it cannot be surpassed. Big white, tender heads. This grand variety has proven its worth and is still growing in favor. Very few outer leaves, of light green, inner leaves blanched to a beautiful creamy $w \bar{h}$ ite. Pkt.. Tor: ox.. 20e: $1 / 4$ lb., 65e. Postpaid.

MAY KING-A handsome, extremely early, compact, cabforming very firm heads of medium size and excellent quality. Color light yellowish-green, tinged with reddish-brown when mature. Inner leaves blanch rich golden-yellow, very very compact for so large head. Exceptionally early outdoors, attaining a siz suitable for use before other sorts and also very Pkt., 10e: oz.. 20c: $1 / 4$ lb. 65e. Postpaid.

WIITE SUMMER CABBAGEA head lettuce of remarkfine head of good size, and will withstand heat and drouth, making it a good late variety. Pkt., 10 , good 20c; x/4 1b., 65e. Postpaid.

$$
\text { ow., 15c; } 1 / 4 \text { King }
$$

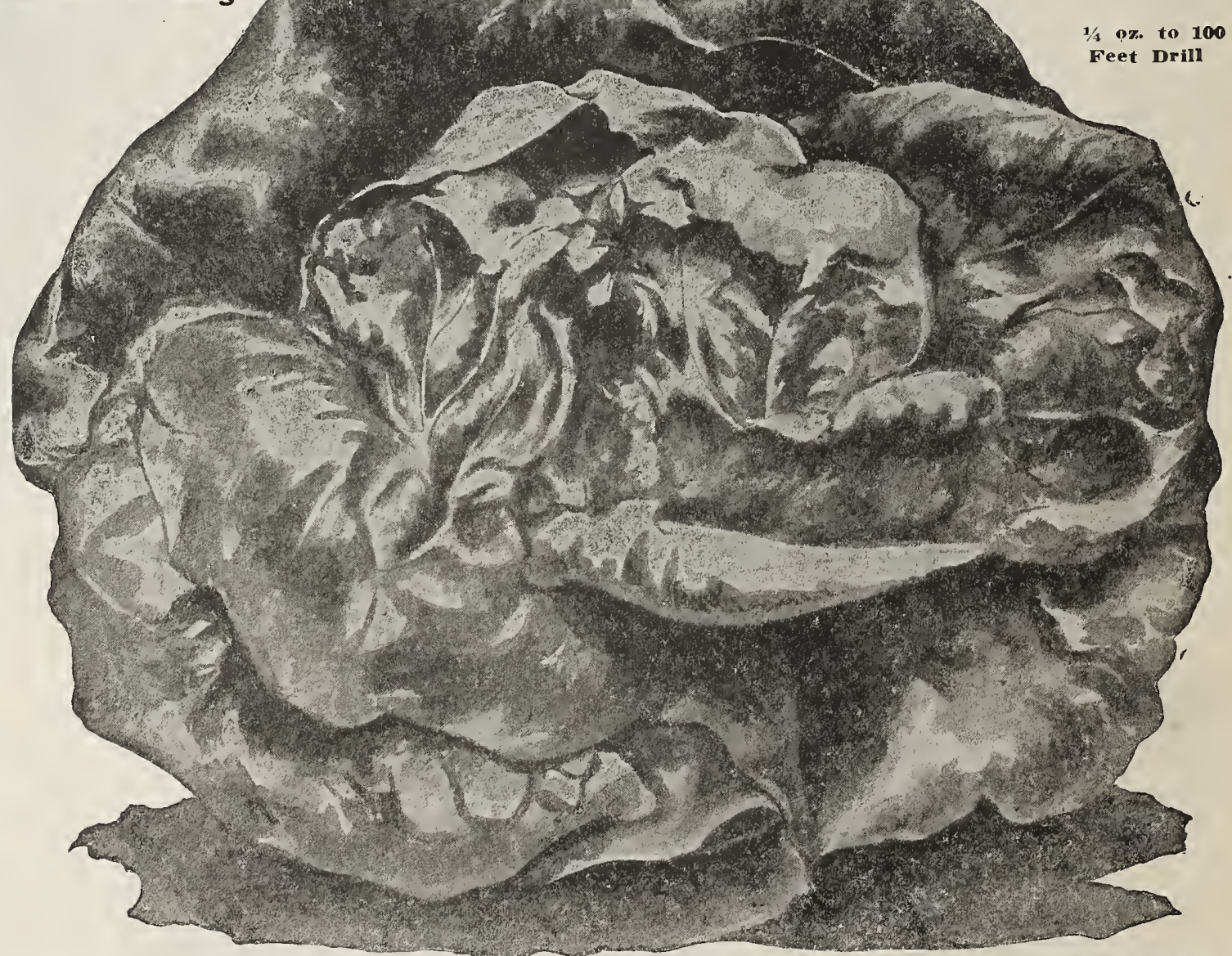

CHAMPION MOSS CURLED-This is a vigorous, compact growing variety, excellent for garnishing and flavoring, and a handsome decorative plant. Leaves very finely cut and so closely crisped fine curled as to resemor and ches attractive foliage this is one of the most popular sorts for both the market and home garden. the most popular sorts for both the market and home garden. GXTRA TRIPLE CURLIA--Very finely curled variety of dark green color. One of the best varieties for all purposes. Pkt., 5e: DOUBt, CU/4 lb., 40e. Postpaid. variety for garnishing meats. Pkt. 5e; oz., 10e; $1 / 4$ lb., 20c. Postpaid. is also versey is used for seasoning soups and stews, for salads, and borders in the flower garden; succeeds best in rich, mellow soil. As the seeds germinate very slowly, three or four weeks sometimes lapse before it makes its appearance. It should be sown early in
the spring. there are Honson-In all probability outd forms immense heads, is an the earliest spring to late in the and late outdoor culture. Stands heat and Leaves large, thin and very pkt., 5c; oz., 15e; $1 / 4$ 1b., 60e. of any other kind, if the truth of wat soil in can also be grown plenty of water is given it. Directions w5: oz.. 30c. Postuaid.

GOLDEN BALL BUTTERCUP-An improved a golden yellow, retaining its color pearance and very sweet and tender. Pkt., EARLY CURIED SILESIA-The old favorite; of dwarf compact habit and quick UPLAND CrESS-Has highly prized flavor of water Cress Green all year; ready for 5e: oz.. 15e. Postpaid.

WATRR CRESS-(Wasser Kresse; Cresson.) The pleasant flavor of Water Cress makes it one of the most delicate salads. It 
CULTURE-The soli for Musk Mellons must be light, rich and sandy, for if grown on a heavy soll the quality will be poor, and they will not be so early. When there is no danger of $2 r 0 s$, soon as a plant commences to run, thin out to 3 best plants in a hill and cultivate until the vines cover the ground. If slow to fruit, pinch off the ends of the growlng shoots. Ash or air-slaked lime sifted on the young plants while the dew is on is
plant about 60 hills, and it takes 3 pounds to one arre.

THE NEW GEM MUSK MELON-Red-fleshed and more eiongnated than. Rocky Ford. If you are growing for the market be sure to make your crop one of GEMS. Average about inches in length and 5 inches through. ing-red, very thick and fine-grained. Sweet and luscious. World-famous for its captivating flavor. Its size, shape and quality exactly suit the orous, bearing an enormous quantity of fruits during the the 作 and at such high prices as the aring clusion of other varieties. The netting is prominent flesh is very deep, ripening clear to the rlnd, very solid, yet thoroughly melting, and it has an exceedsolid, yet thoroughly melting, and it has an exceedgrown for us by a careful grower at Rocky Ford, and grown for us by a careful grower at Rocky Ford, and 1s the best type of the genuin.

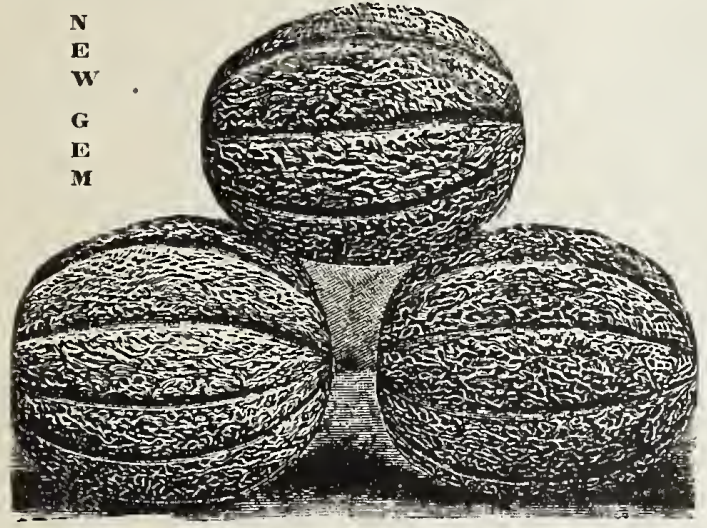

EXTRA EARLY HACKFNSICK-Ripens fully ten days ahead of the Old Hackensack, which it much resembles Fruit large, round and deeply netted. Pkt., 5e: oz., 15e 1/4 1b., 50c: lb.. \$1.75. Postpaid.

JENNY WIND-Fruit small, globular or a little flattened, deeply ribbed with green flesh, which is exceedingly sweet. Pkt., 5e; oz., 15e; 1/4 lb.. 50c; lh. \$1.50. Postpaid. ONTRWAL MARKET-Large size. Flesh very thick and pald.

GARLY GREEN NUTMEG-A rather small green-fleshed variety. Dark green rind, well netted, ribbed and globular in shape. Extra early. Pkt., 5c; oz., 10c; $1 / 4$ 1b., 35e lb.. \$1.25. Postpaid.

EMERALD GEM-A most delicious small Melon. Extremely thin rind. Flesh of a beautiful salmon color. almost red. Flavor un

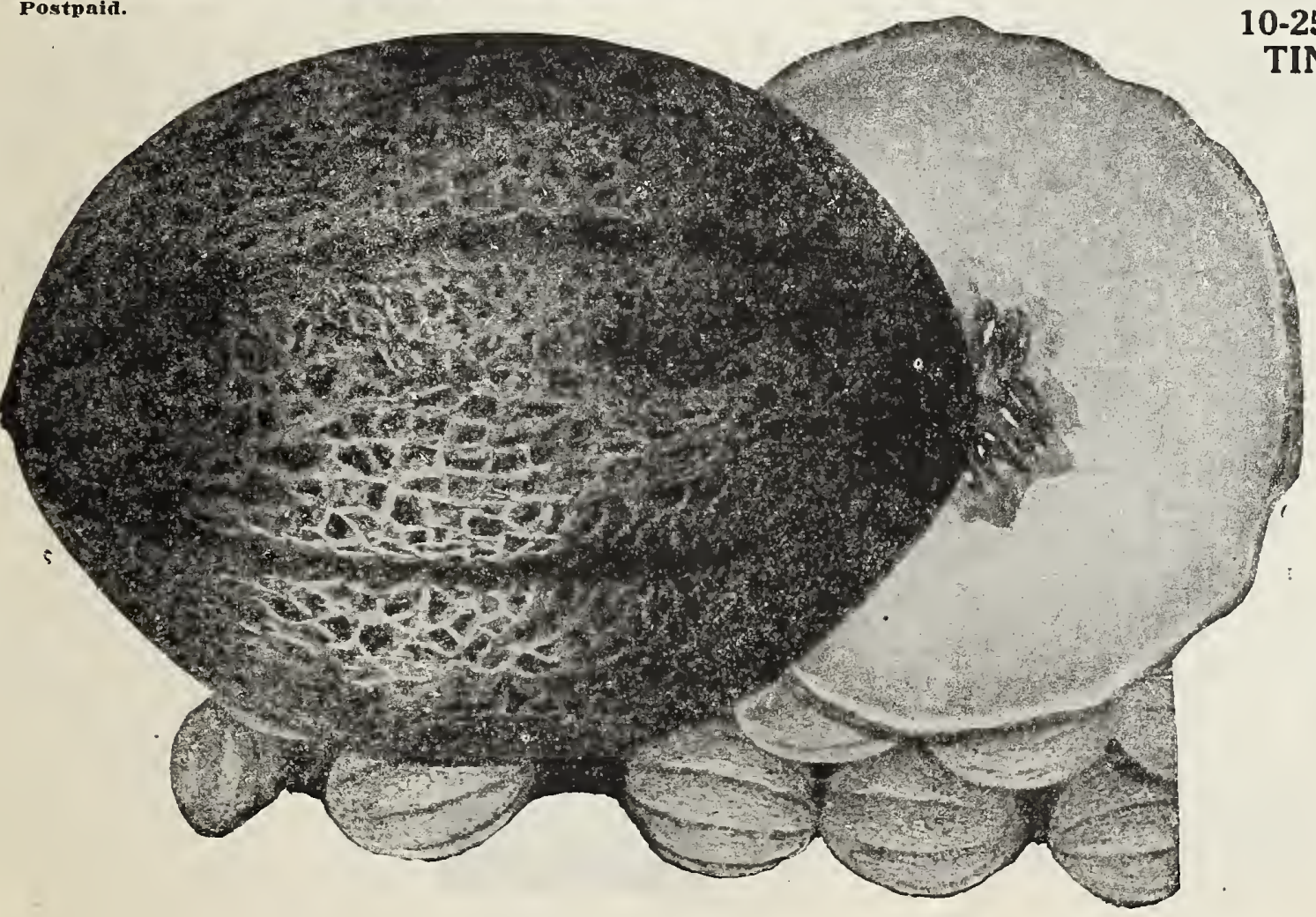

CHAMIIUN MARKET-The fruits are large, round or slightly oval, slightly rlbbed and covered with dense netting. The flesh is green, very thick and sweet. The variety is an improvement on Montreal in earliness and productiveness and will suit those who like a large, sweet, green-fleshed sort. It can always be depended upon for a good crop.

CHiCAGO MARIER-A very large nutmeg. Uniform green, very juicy and sweet, delicious flavor. Seed cavity very small. Seldom crack or rot. Excellent for late market. Fkt., 5c; oz., 10e; 1/4 lb., 35e; lb.

BANANA-Pkt., 10c; oz., 20c; $1 / 4$ 1b., 00c; 1b., \$2.00. Postpald.

ARGE HACKENSACK-Very large, green-fleshed Melon. Vines hardy, vigorous and productive, Fruits nearly irregular width, densely covered with coarse netting. Flesh green, thick, coarse but juicy and sweet. Plet. Fc; oz., 10e: 1/. lb., 50e; lb., \$1.50. Postpaid.

LONG YELLO ${ }^{1 / 3}$ lb., 50e; lb., \$1.50. Postpaid, ribbed. Flesh thick, light salmon-colored and of a peculiar musky flavor. This variety is used in its lb., \$1.50. Postpaid.

VEGETABLE PEACH (MANGO MELON OR VINE ORANGE)-Size and color of an orange. Excellent for ORANGE)-Size and color of an orange. Excellent for
preserving and mangoes. Pkt., se; oz., 15c; 1/4 lb., s0c. Postpald.

OSAGE OR MLLER'S CREAM-Skin is sightly netted, dark green color. Being a heavy cropper and of fine flavor, this old-time favorite holds its own. Pkt.o ses oz, 15e: 1/4 lb., 50e: lb.. \$1.50. Postoaid.

GENUINE ROCKY FORDA sweet, luscious Melon that has grown world has proven to be the most vaiuable Musk Melon. The vines are exceedingly healthy and vigorous, bearing an enormous quantity of tire season. The color of the skin is of a the netting is promi nent and light in color: appearance fiesh attractive. The ripening very deep, rind, very solid, yet thorough ly melting, and it has an exceedingly small seed cavity.

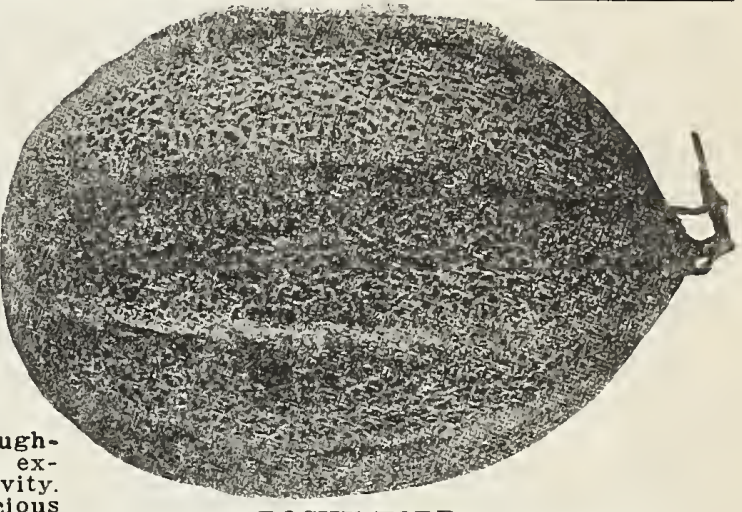

ROCKY MORD

in flavor. Our seed was specia the genuine Rocky Ford Musk Melon. Pkt., 5e; oz., 10c; 1/4 lb., 50c; lb. \$1.s0. Postonid.

\section{MUSK MELON}

One of the new main crop melons that is gaining in popularity every season by proving its superior quality and delicious flavor, equaled by no other melon. The 1025 Pollock has gained in favor and is sought after by the most exacting.

Beautiful salmon color, light green outside, netted and ribbed, oval in shape. Most delicious flavor and elegant shipper. Small seed cavity and flesh solid and crispy, does exceedingly well on most soils but reaches its best on a light, sandy soil. Pkt., 10c; $\mathrm{Oz}, 15 c$; $1 / 4$ Lb., 50c; Lb., \$1.75. Postpaid. 


\section{RHUBARB OR PIE PLANT}

Culture-Sow in spring in seed bed, in drills 1 foot apart. Cultivate well during the season. The stalks should not be cut before the third year. For immediate use order the roots, which come into use at once.

PIONEER STRAWRERRY-Beautiful rich strawberry color. Long stalks, large size; early and very seldom runs to seed. One of the best for canning. Pkt., 10c; oz., 25e; 1/4 lb., 75e. Postpaid. LINNAEUS-Large and tender: the very finest of all. Pkt.. 10e: oz., 25e: 1/1/ 1b., 50c. Postwaid.

VICTORIA-In general use for market and home garden. Pkt., 10c; oz.. ROOTS-10c each; $\$ 1.00$ per dozen, by mail, postpaid.

\section{KALE OR BORECOLE}

Culture-IKale is one of the hardiest of "Greens," belonging to the Cabbage family. Makes, excellent greens for winter and spring use. For early spring during August and September. One or two pounds to an acre.

STBERIN-One of the best known and most largely used varieties of Kale. It is sometimes called verouts or German Greens. The green leaves are but coarsely cut and distinctly frilled on the edge. The plant is low but spreading and very hardy. DWARI CURLED SCOTCH, OR GWRMT GRELTS Plat., 5e; oz., l5e; $1 / 4$ lb., 35e; lb., \$1.25. Postpaid.

\section{MUSTARD}

CULTURE-The leaves of these varieties of Mustard, as here listed, make excellent greens of sharp, pungent flavor, and are cooked the same as spinach or beet leaves. Sow the seed in drills early in the spring and at frequent intervals throughout the summer to secure a constant supply of fresh greens. Mustard is hardy and is easily grown. One ounce will sow 50 feet of row.

OSTRICH PLUME-Most beautiful variety of very superior flavor. The leaves are beautifully ruffled and curled and curve outward like graceful ostrich plumes. They are excellently adapted for garnishing. It originated in the south and stands hot weather extember and October. Pkt., 5e; oz., 10e; 1/4 1b., 25e; 1b., 60e. Postpaid.

SOUTHERN GIANT CURLED-Is highly esteemed in the South, where the seed is sown in the fall and plants used in early spring as a salad. Seeds brown. Plants are 2 feet high; en
bunches. Pkt., 5c; oz., 10c; 1/4 lb., 20c; 1b., 60c. Postpaid.

CHINESE-A giant curled variety with leaves double the size of the ordinary. Pkt.. 5c; oz.. 10c; 1/4, 1b., 25e; 1b., 60e. Postpaid.

WHTE ENGLISH-Leaves are light green, mild and tender when

young; seed light yellow in color. Pkt., 5e; oz., 10c; 1/4 lb., 20c;

BROWN OR BLACK MUSTARD-More pungent in flavor than the

white. Seed black. Pkt., 5c: oz., 10e: 1/4 1b., 20c: 1b., 40c. Postpaid.

\section{DIAMOND MARKET BASKETS}

Just what you want to ship out rour Beans, Peas, Tomatoes and other rarden truck. Postpaid.

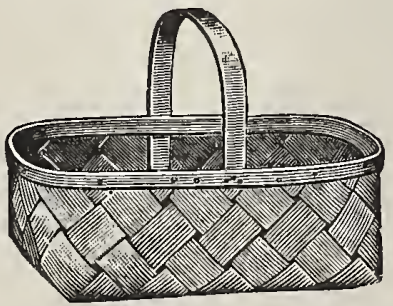

\section{TOBACCO SEED 1 oz. will sow \\ TOBACCO SEED ${ }_{450 \text { square } \mathrm{ft} \text {. }}^{1 \text { oz.ll sow }}$}

The soil and wonderful climate of southern Missouri has revived the growing of Tobacco here. Hundreds of acres will be put in this year and the income is double that of wheat, corn or oats. Last
season there was paid out tens of thousands of dollars for southern Missouri leaf.

\section{JUDY'S PRIDE}

This type of white Burley is the best of any variety grown in this section. Makes the largest yield and the highest grade of leaf, which is much superior to that grown in other sections. Good bright per oz., \$1.00. 50e Per Oz.

for the following varieties:

Red and White Burley, Sw e et Oronoco, Yellow Pryor, Missouri Broad Leaf, Cuban Seed Leaf, Big Havana. Postpard.

\section{HERBS}

Pot Herbs are a most desirable feature of the home garden. They may be freshly gathered for flavoring during the summer months, and the young stems and leaves can be gathered, tied in bunches, and dried for winter use. In a few varieties the seed is used for flavoring. These should be planted in drills or rows and threshed out when the seeds ripen. ANISE-(Pimpinella anisum.) An annual; native of Asia Minor, Greece and Egypt. Used for garnishflavor. Prefers a the seeds have an aromatic rapidly and requires little care ploil. 35c. Postpaid.

BALM-(Melissa offcinalis.) Perennial. The leaves have a fragrant lemon-like odor, and are used for making balm tea. Pkt.,

CARAWAT-(Carum carvi.) Biennial. The seeds are used for flavoring bread, pastry, cheese, sauce, etc. Pkt., 10c; oz., 15c. Postpaid.

CORIANDER-(Coriandrum sativum.) A hardy annual; native of Southern Europe. The seeds have a strong aromatic flavor and are used in the manufacture of confectionery and pastry. Pkt., 10e; oz., 25e. Postpaid.

DILL-(Anethum graveolens.) A biennial grown as an annual. The seeds have a strong aroma and a pungent taste. Used as a condiment, also for pickling with cucumbers to prepare the so-called dill
pickles. Native of southern Europe. Pkt., 10e oz., 20e; 1/4 1b., 45c. Postpaid.

HOREIOUND-(Marrubium vulgare.) Perennial. The leaves are used for flavoring candy and cough-
drops. Pkt., 10e: oz., 4toc. Postingid.

LAVENDER-(Lavandula spica.) Perennial. The variety generally sold. It has an agreeable mild fragrance. Pkt., 10c; oz., 40c. Postpaid.

MARJORAM, SWEET-(Organum marjoram.) Grown as an annual The leaves and the ends of the shoots are esteemed for seasoning in summer, and they are also dried for winter use. Pkt., 15c. Postpaid.

OSEMARY-(Rosmarinus officinalis.) Perennial. The leaves are used for seasoning and for making oil of rosemary. Pkt., 20c; $1 / 4$ oz., 65e. Postpaid.

UE-(Ruta graveolens.) Perennial. For medicinal purposes; good for fowls. The leaves have a strong odor and acrid taste. Pkt. 10c. Postpaid.

AGE-(Salvia officinalis.) Perennial. The most extensively used of all herbs for seasoning. Pkt., 15c. Postpaid.

UMMER SAVORY-(Satureia hortensis.) Annual. The leaves and flowers are used for flavoring. Pkt., 15c. Postpaid.

HYME-Leaves and tender shoots used for seasoning during summer and dried for winter. Delicious flavoring for sausage and wormwood-(Artemisia absinthium.) Perennial. Pkt., 10c. Post-

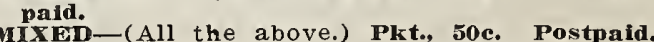

\section{LEEK}

LARGE AMERICAN FLAG-Hardy and of excellent quality. Pkt., GIANT CARENTAN-Favorite market variety. Large thick stem, mild flavor and attractive appearance. Pkt., 5e; oz., 25e; $1 / 41$ lb.

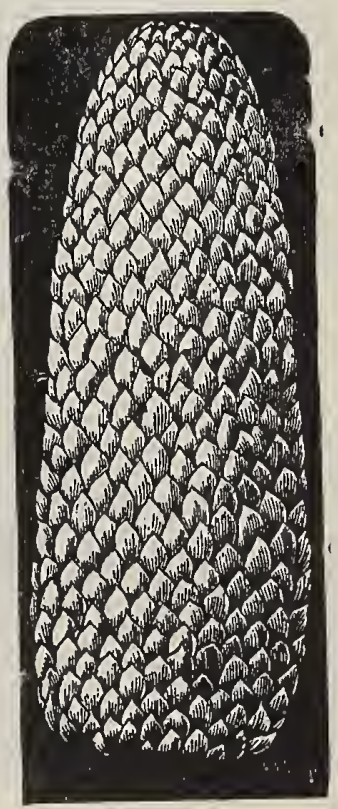

\section{POP CORN}

Plant 4 Lbs. per Acre JAPANESE HULLESS OR BABY RICE-Is dwarf growing corn, at is very paruliar in have yielder ing sometimes nearly as thick as long; is absolutely the best popping corn grown. Has a flavor all its own, which is most delicious. almost melting in your mouth, is a great favorite with the poppers as it leaves no husks or hard shell when popped. Pkt., 10e lb., 25e; 5 lbs., \$1.00. Postpaid.

WHITE RICE-A very handsome and popular variety; ears short, kernels long, pointed, and resembles rice; color white. Pkt., 10e; 1b., 20c; 5 los., 75c. Postpaid.

QUEEN'S GOLDEN-The. largest pop corn. The stalks grow five to six feet high, and bears two or three large ears each. It is yellow, but pops perfectly white. Postpaid.

MAPLE DALE PROLIFIC-Ears uniformly large, kernels, nearly clear white and smooth. Pops large and tender. Pkt., 10c: lb., 20e; 5 lbs. 75e. Postnaid. 

or sets the seed should be sown very thickly and in broad drills, about 50 pounds to the acre for sets, and 15 to 20 pounds for pickling. When the tops become dry and dead, pull and spread over the ground for a few days until thoroughly dried. Cut top half an inch from the bulbs.

\section{RED GLOBE—Southport}

\section{UNIVERSALLY POPULAR}

A leading variety in all sections. Produces enormous crops of immense size onions. Clean, solid, heavy and perfect. No thick necks, sure cropper and long keeper. Our stock is excellent, being saved from selected bulbs. The surface color is rich dark red and flesh sparkling white. Very mild in flavor which makes it one of the very best for table use. Pkt., 10c; oz., 20c; $1 / 4$ lb., 65c. Postpaid.

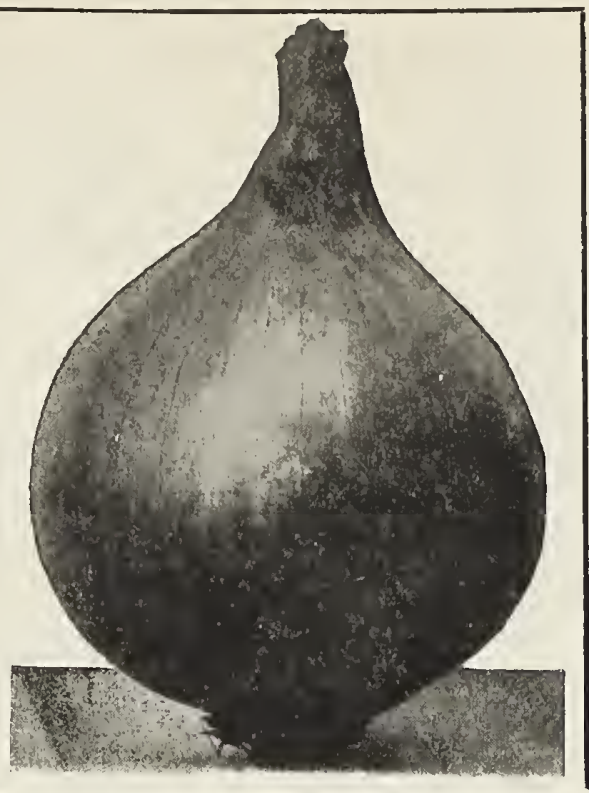

PHIZETAKER-This is beyond question the handsomest Onion grown. Yellow or straw color, flesh white, of enormous size, in many cases weighing from 3 to $31 / 2$ pounds, Very hardy and a good keeper. Flavor sweet, very mild and tender. The seed we offer is a very superior strain and comes from a reliable and trustworthy grower.

WHITE QUEEN-This is the best of all for small pickles and the earliest ripening onion in cultivation. The bulbs, of a pure paper-white, are generally very small, av-

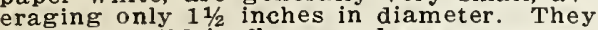
are most mild in flavor and are grown extensively for commercial and home pickling. Also grown for early use. Pkt., 10c; oz., 25e; 1/4 lb., 75e; 1b., \$2.50. Postpaid.
WHITE PORTUGAL, OR SILVER SKINStandard white variety for general culture. Bulbs grow to good size, ripening early and quite evenly. A good keeper. Flesh is very mild and sweet, the skin a clear. silvery white, of very handsome appearance. Used by market gardeners, also used for growing sets and pickling. Pkt. 10e: oz., w5e: $1 / 4$ lb., 85e. Postpaid.

SOUTHPORT WHTE GLOBE-The handsomest market variety; beautiful, clean, pure, silvery white bulbs of large, even size, globe-shape, mild and pleasant flavor, and outsells every other variety. Undoubtedly the best white sort. Will yield as many bushels per acre as any variety.
Pkt., 10e; oz., 25e; 1/4 lb., 85e. Postpaid.
LARGE HED WETHERSFIELD-The old standard variety so largely grown for commercial purposes. A magnificent keeper and enor mous yielder. Color, a dark purplish red. Our strain of this variety is grown from well se-
lected bulbs by one of the most reliable lected bulbs by one of the most reliable growers in the country, and is being grown
successfully and profitably. Pkt., 10e; oz., successfully and profitably. Pkt.,
20e; $1 / 4$ ib., 55e; 1b., $\$ 2.00$. Postpaid.

GIANT RED ROCCA-A large, globe-shaped Onion, with light reddish brown color. In size and ripen early. Pkt., 10e; oz, 40es $1 / 4$ lb., \$1.25. Postuaid.

EXTRA EARLY RED-Flat in shape. Light red in color. The earliest of all red Onlons. Pkt., 10e: oz., 20r: 1/2 lb., Gife. Postnaid.

YELLOW GLOBE DANVERS-A very handsome, round American variety of large size. Very fine and mild. An excellent keeper

FLAT YELLOW DANVERS-A fine keeper. per. Pkt., 10e; oz., 20e; 1/4 lb., 60c. Postpald.

BERMUDA ONIONS-Planted extensively by the market gardeners in the South for shipping. These Onions grow to an immense size, and are of a fine form. The skin is thin, flesh white, fine grained, of mild and pleasant flavor. Will make an Onion from 1 pound to $11 / 2$ pounds from seed, but to grow full size Onions set out the bulb the following spring. White or Red Bermuda.

GIAN'T WHITE ITALIAN TRIPOLI-(El Paso or Large Mexican) Large bulbs, beautiful form, and pure white skin. Under proper cultivation, can be raised in a single season from seed, weighing from 1 to $1 \frac{1}{2}$ pounds, but will attain much larger size from sets grown in the spring and planted out in the fall to produce an early crop for the following season. Pkt., 10e; oz., 20e: 1/6 1b., 75e. Postpaid.

MAMHOTH SILVER IING OR WHITE GARGANUS-An Italian variety, remarkably early and of enormous size, single bulb weighing from 2 to 3 pounds. Flat in shape and very delicate flavor.
oz., 25e; 1/4 th.. 75e. Postpaid.

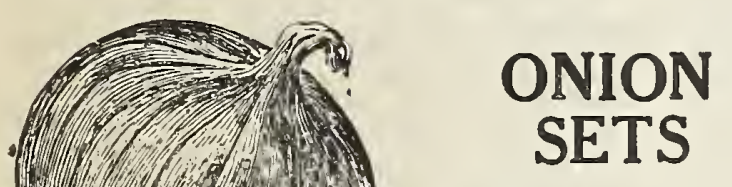

Bottom sets 32 Plants are fast taking lbs. a bu. Top the place of sets as sets 28 lbs. a bu. they make a larger Plant 8 bu. per acre.

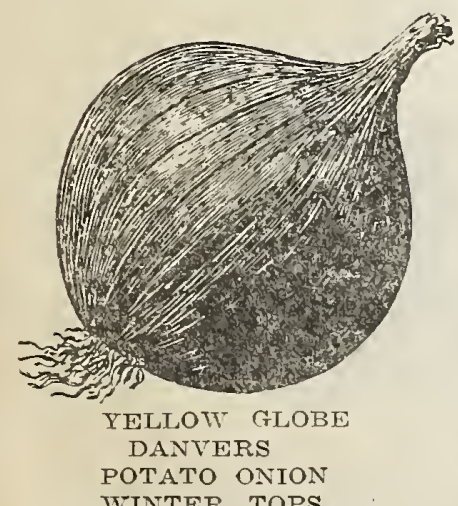

We can furnish the following varieties:

\section{ONION PLANTS}

Bermuda $\mathrm{O} n$ i o $\mathrm{n}$ and better onion and do not have the objectional seed stalk to ruin the onion.

We sold several h u $\mathrm{nd} \mathrm{red} \mathrm{thousand}$ plants last year and every one was more than pleased. We RED WETHERSFIELD can furnish the plants YELLOW DANVERS this season at 35c per WHITE SILVER KING hd. Postpaid. Write MULTIPLIERS
SUMMER TOPS for prices on larger

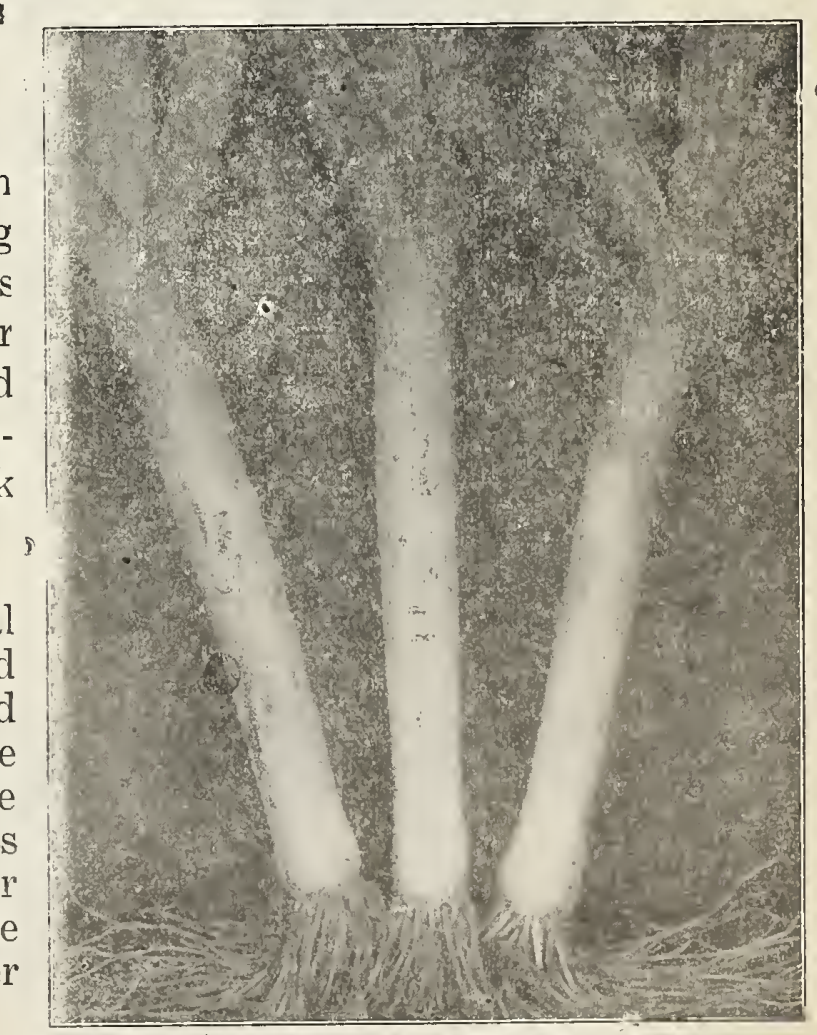




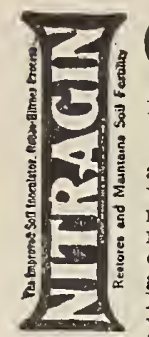

GARDEN PEAS

Pound to $100 \mathrm{ft}$. Drill, 55 to 100 Pounds CULTURE-Peas are a fine vegetable, and therefore are very generally cultivated. It is best to plant in ground manured the previous season, else they will make more vines than peas. As a general thing the dwarf kind require richer ground than the tall growing varities. in sandy light soil. The produce wel Tom Thumb and Alaska will not produce a large crop without being in rich ground. Peas have to be planted in drills two inches deep they may grow. Premium Gem can be planted one foot apart, whereas the White Marrowfat or Champion of England require 3 feet. The Extra Early, toring August cember we plant the Marrowfat; January and Eebruary, or as late as March, all kinds can be lanted; but for the latter month only the earliest varieties should be used, as the late varieties will bear much better if some brush or rods are stuck in the drills to support them, except the very dwarf kinds.

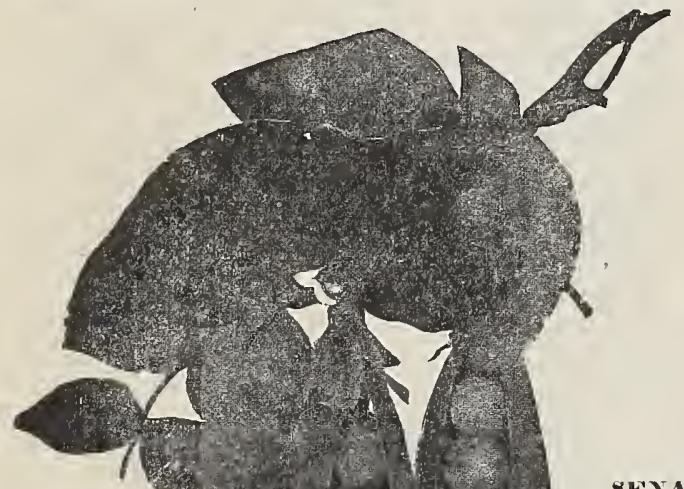

QWNATOR-4 ft. The introduction of this excellen pea a few vears ago has proven so satisfactory to the growers that we have had considerable demand and every grower who was fortunate demand, and ex some was extremely pleased at his good fortune. Has dark green foliage, profusely good fortune. Has dark green follaty of large well filled pods of delicious sweet peas that mathe lb., 35e: 5 lbs., \$1.50. Postpaid.

GRADUS, OR PROSPERITY-This remarkable Pea is not only large and of the best quality, but is also nearly as early as the small, round, extra early sorts. It is hardy and may be planted as soon as the ground is fit to work in the spring. along with smooth peas. The vine grows to a height of about 30 inches. The pods are of a ight green color and measure 4 inches or more in length, being as large as Telephone and equally as well-filled with luscious Peas -8 to 10 in a pod. The Peas are of first-class table quality and retain their color and attractive appearance after cooking. It is a grand Pea in all respects. pkt., 100: Ib.. 2we: 5 lbs.. \$1.25. Postpaid.

ADVANCRR-A green tvrinkled variety of medium heicht about $23 / 4$ to 3 inches long, which are abundantly produced and well filled to the ends. This Pea is used very extensively by market gardeners because of its productiveness, the fine appearance of its pods, and is popular with consumers on account of its quality. It is also largely used Postpaid.

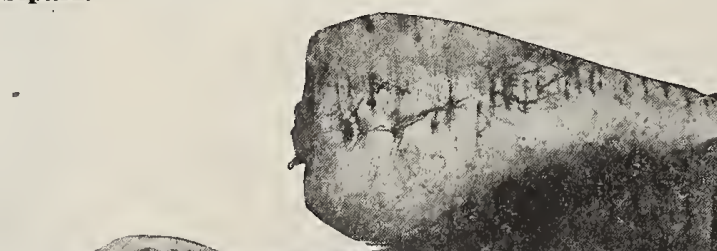

CULTURE-They do the best in deep rich sandy soil, but will make good roots on any soil which is deep, mellow and moderately rich. As the seed is slow to germinate, it inch deep, and press the soil firmly over the seed; give frequent cultivation. and thin the plants 6 to 8 to the foot. As they are improved by frost, a part of the crop should ounce will sow 100 feet of drill, 5 pounds an acre.

LARGE SUGAR OR HOLLOW CROWN-The market gardener's favorite. Considered the best for general culture
15e; $1 / 4$ lb., 40e. Prepaid.

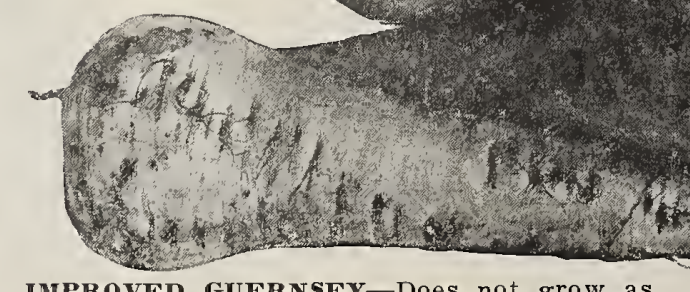

IMPROVED GUERNSEY-Does not grow as long as the Hollow Crown, but of greater diameter. Quality excellent. Pkt., 5e; oz.,
I5c; $1 / 4$ lb., 40c. Postpaid.

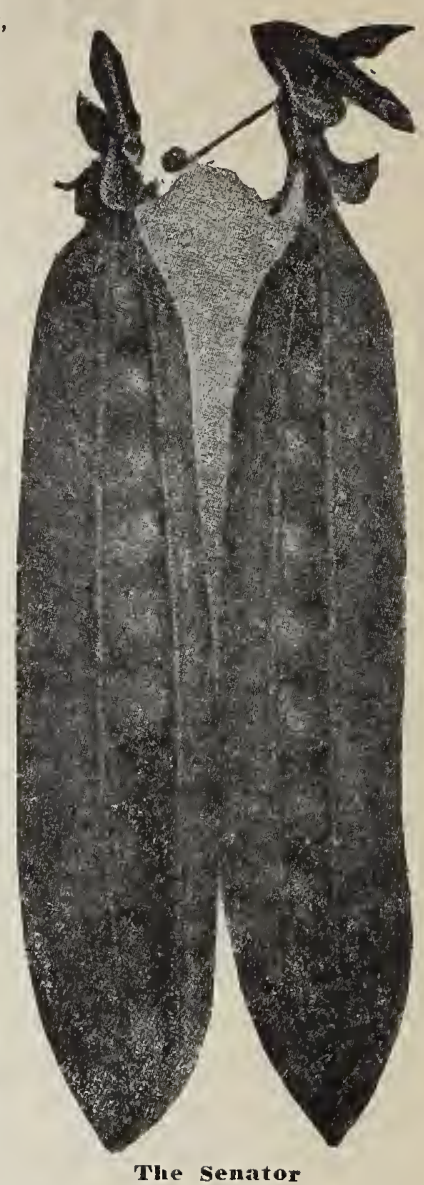

BLISS EVERBEARING-Grows $2 \frac{1}{2}$ to 3 feet high. The pods are from 2 to 4 inches long, containing from 6 to 8 splendid peas of rich, sweet flavor. Pkt., 10c; lb., 35cs 5 lbs., \$1.25. Postpaid.

ARUNDANCE-Three feet. A deservedly popular variety, branching from the bottom and bearing abundantly roundish pods 3 to $31 / 2$ inches long, filled with 6 to 8 large, wrinkled Peas of excellent quality. Pkt.,

HORSFORD's MARKET-Two feet wrinkled Pea, noted for its uniform growth, and prodigious yield. The pods, though of medium size, are packed with Peas of sweet, delicious flavor. Pkt., 10c; lb., 35e; TOM THUMB-Smooth, one foot high. Pkt.,
10c: lb., 35e: 5 lbs.. \$1.25. Postpaid.

FIRST AND BEST-An excellent strain of first early Peas; very popular and largely planted through the trucking sections. Height 2 to $2 \frac{1}{2}$ feet. Pkt., 10c; 1b., 35e;
5 lbs., \$1.10. Postpaid.

PHILADELPHIA EXTRA EARLY-Smooth, 2 feet high. Pkt., 10e; lb., 35e; 5 lbs.,

HOLLOW CROWN PARSNIP 


\section{SEED POTATOES ${ }_{\substack{60 \mathrm{Bu} \\ \mathrm{Bu}}}^{60}$}

\section{NORTHERN GROWN, CERTIFIED STOCK}

Plant 8 Bushels Per Acre

Don't let price influence you in buying your seed potatoes. Our Certified Potatoes have proven so much superior to the common stock offered to the trade at a much lower price that we will have only certified seed this season.

\section{LATE VARIETIES}

BURBANK-The best late sort for our section, a good cropper and an excellent keeper. We handle only the fln est seed stock. We can supply for the greater part of the season many varieties not inclu
Write for prices.

RURAL NEW YORK-Quite distinct in appearance; flesh white, quality excellent; shape nearly round, somewhat flattened. Tubers large to very large, but not rough or irregular, eyes quite small; form symmetrical. One of the best late sorts. An enormous yielder.

WHITE NORTHERN-Doubtless the most popular late Potato of the new varieties. It yields a great crop of fine, large, smooth Potatoes, even under the most unfavorable circum stances, and can be relied upon to bring in money. Its good appearance. uniformity of shape, size and pro ductiveness makes this a leading variety to grow for market. The skln and flesh are extremely white, no hollow or dark parts. Cooks up dry prices.

GREEN MOUNTAIN-Best general crop Potato in cultivation. Large fine grained, cooks dry and mealy and is of fine flavor. Keeps perfect. Flesh
and skin white. Write for pices.

\section{EARLY VARIETIES}

RLISS TRIUMPH-A handsome variety and ls wonderfully productive. The tubers are not large, but are of a flne medium size for early use, round as a ball. and a beautiful color. For several years it has been the most popular variety in the Southern Write for prices.

\section{Use Formaldehyde for Potato Scab}

The old method of treating seed Potatoes for $11 / 2$ to 2 hours elther with cold formaldehyde or corrosive subllmate has been superseded by the Iowa method. Use 1 pint of formaldehyde to 15 gallons of water. Heat solution 118 deg. to 122 deg. Fahr. in tank with heater. nor wh will effectually treat black leg, black wcurf, common scab and dry rots. For larger lots, use larger tank heated wlth larger lots, use larger tanall lots can be steam from boller. Small lots can be Write for prices.

WRLY SIX VEEKS-This is undoubtedly the most wonderful Potato edly the most wonderful Potato it is ready for the table in six weeks. It is ridy it is nice, smooth and uniform in market gardeners and home growers to ket gardeners and home growers to Spuds." we have known growers to have "Six weeks" on the market before other varieties were in bloom. before other varieties were in bloom. ine vines are stocky and short gro to ing and the potatoes cluster close to the main root, which makes digging them an easy matter. 1 peck, py cxpress, prepaid, \$1.00; 1 bu., prepaid IreIgh, \$3.00- RED RIVER STOCK..Especial attention is called to thls Especial attention is called to thls strail of Ohios for market purposes. They are all of good average sizes, strictly pure, smooth and free from sorts. It is an especial favorite with marketmen. and the most profitable Potato they can grow. Excellent Potato they can grow. Wxcellent
keepers and shippers. Wrlte for prices.

TRUE EARLY ROSE-The Early Rose is a standard early Potato and is so well known as to need no descrlption. Before you buy, it will pay you

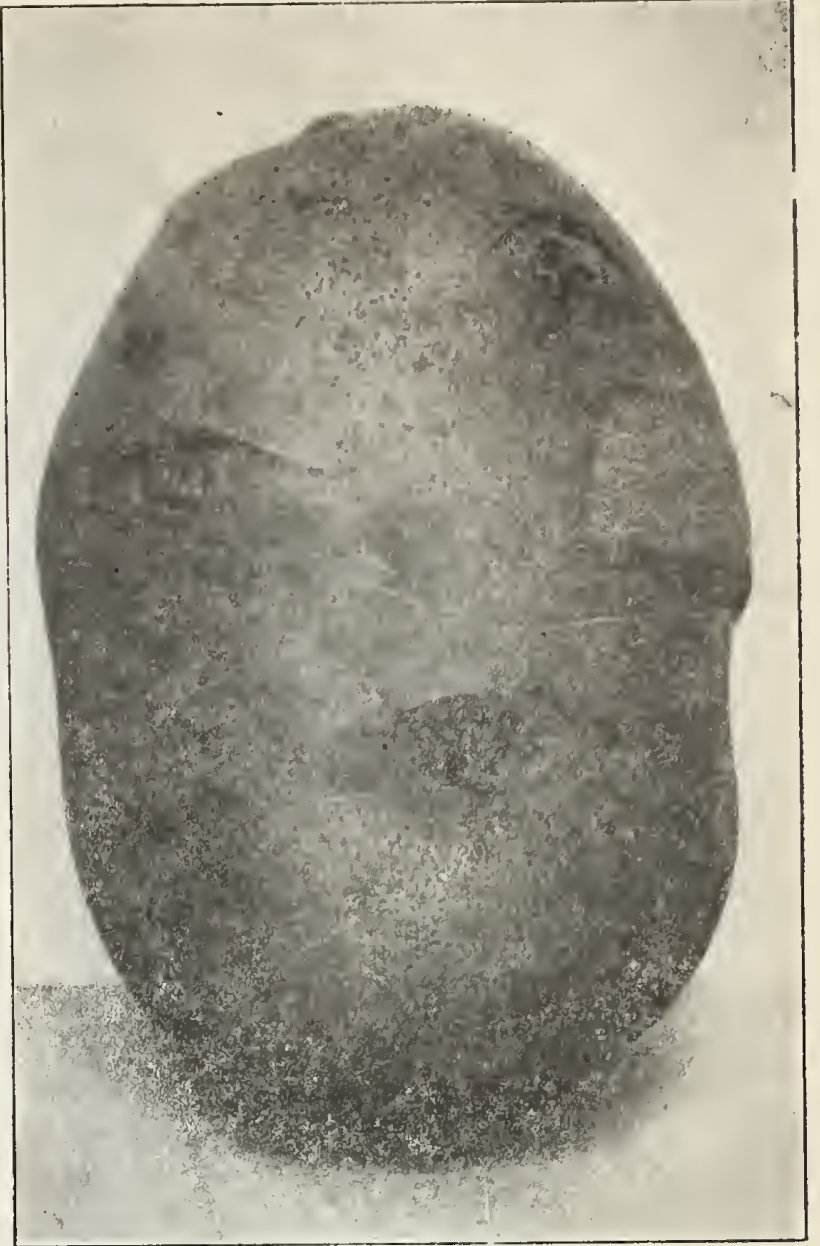

IRISH COBBLER

Send us an estimate of the Certified Seed Stock you will want.

IRISH COBBLER-This is a most excellent early variety, maturing good size tubers 7 weeks from the time planting. It has also the remarkable characteristic of producing very few, if any, small Potavines make short upright may me hllls may be only a short distance apart. Skin is clean ity, always cooking dry and mealy. Write for prices.

\section{SEED SWEET POTATOES}

Plants ready for shipment about April 15. Write for Prices

$\begin{array}{ll}\text { YELLOW KINDS } & \text { RED KINDS } \\ \text { NANCY HALL } & \text { RED NANSEMOND } \\ \text { YELLOW NANSE- } & \text { RED JERSEY } \\ \text { MOND } & \text { RED BERMUDA } \\ \text { YELLOW JERSEY } & \text { KEY WEST } \\ \text { UP RIVER } & \text { YHITE KIND } \\ \text { YELLOW YAM } & \text { BRAZILIAN QUEN } \\ \text { EARTY GOLDEN } & \text { SOUTHERN QUEEN } \\ \text { PORTO RICA YAM } & \end{array}$

Owing to the perishable nature of Sweet Potoes, our responsibllity ceases upon delivery tatoes, our responsib and receipted for in good conditlon.

\section{BIRD SEEDS}

Cuttlebone

Postpaid. Per Lb.

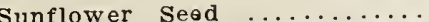

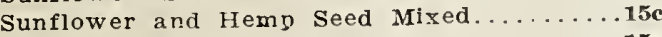

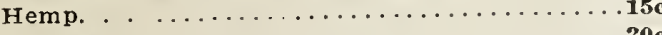

Canary.

Bird Rape

Bird Millet

Mixed Blrd Seed

\section{SPINACH} CULTURE-Requiring but llttle culture, it is one of the most easlly managed of all
vegetables. The main crop is sown in September. If in exposed places it is sometlmes cogered with straw during the winter, which prevents it being cut by a frost. For summer use it may be sown at intervals of 2 or 3 weeks, from March to August. Spinach is best developed. most tender and succulent when grown in rich soil. One ounce to 100 feet of drill: in to 12 pounds to an acre.

BLOOHSDALE, OR SAVOY LEAVED-Highly popular with market gardeners. Bloomsdale ls considered the best sort for the South. The leaves are wrinkled in the same manner as the Savoy Cabbage. A crop of this variety weighs much heavier than any other variety. It grows.

IMPROVED ROUND THICK LEAF-(Viroflay). The market gardener's favorite for fall or spring sowing. A great favorite in all parts of the country as it furnishes an abundance of heavy. broad, dark green leaves of finest quality and appearance. The leaves are attractively curled, and on account of their firmness and substance they remain in prime, salable condition for a long time. Also excellent for home use. pkt. 5e: oz... 10e: 1/a lh.. 20e: lh.. 5ne:. Postpaid.

PRICKLX WINTER-Extremely hardy. Seed prickly and leaves smaller than the ordinary varieties. Pkt., 5e: oz.. 10c: 1/s lb.. 20c; lb.. s0c. Postpaid.

VICTORIA-An excellent sort, whether grown for home use or market. It may be sown with equally good results either in the spring or during the late summer and fall. The plants are fit for use early and remain in good marketable condition much longer than
most other kinds. The leaves are very thick and juicy and when prepared properly, develop a delightfully distinct. mild flavor. Pkt., 5e; oz., 10e; 1/4 1b., 20e; 1h., 50c. Postpaid.

LONG STANDING-This very valuable sort, slow to seed. Plkt., 5e; oz., 10e; 1/4 1b.. 20c: 1b.. sor. Postyaid. 


\section{OKRA or GUMBO}

CULTURE-Very wholesome. The pods, when young, make a fine soup. Plant seed after the ground is warm and dry in drills 3 feet apart, thinning the young plants to 1 foot apart. Make early and late sowing to secure a supply throughout the season. Easy to grow in any good garden soil. One DWARF GREEN PLOLIFIC-This Is a distinct variety, very dwarf in growth, but enormously productive, producing pods within an inch or two of the ground and clear to the top. Pkt. 5c; oz., 10c; 1/4 lb., 25c Postpaid.

MAMMOTH LONG POD - Plant dwarf but very productive. Pods long, slender, deep green and remain tender longer than most sorts. Pkt. 5c; oz, 10c; 14 lb., 25c. Postpaid.

WHITE VELVET-Distinct in appearance; the large pods are perfectly round, smooth, an attractive velvety white, of superior flavor and tenderness. Plant dwarf of compact, branching growth; very prolific. Pkt., 5c; oz., 10c; 1/4 lb., 25c. Postpaid.

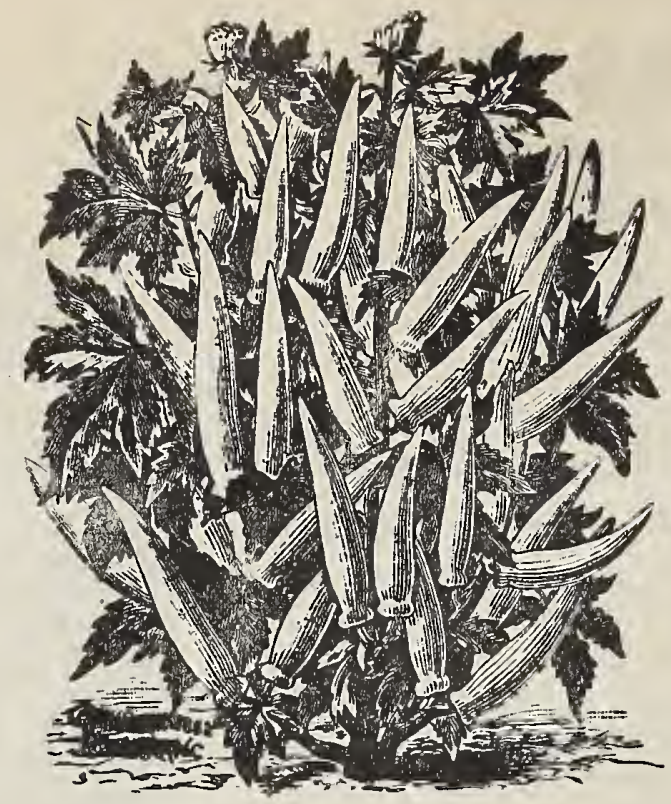

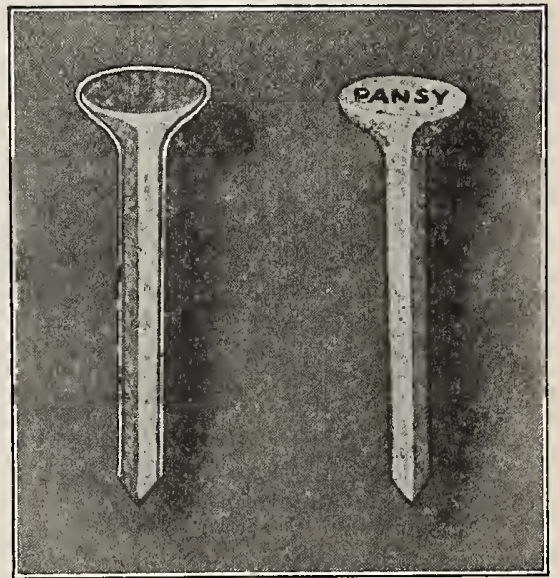

\section{Vegetable Plants}

We have the best equipped Greenhouses and Trial Gardens in the Southwest for growing plants. 30,000 square feet of glass.

We have made very complete preparations to produce plants in quantities. Special prices to growers and canners. All kinds of vegetable plants in season of our own growth. Will ship carefully packed plants at the following prices by express, at purchaser's expense:

SWEET POTATO PLANTS-All the leading varieties. 50c per 100 ; $\$ \mathbf{3 . 5 0}$ per 1,000 .

TOMATO PLANTS-Good, stocky plants twice transplanted. Ready in May and June. 15c per dozen; 85c per 100 . Seed bed plants. $\$ 3.50$ per 1,000 .

HORSERADISH ROOTS-15c dozen. Postpaid.

Give us ample time to select, pack and ship your order promptly. By doing so you will secure better plants. FROST PROOF CABBAGE - Will put you 2 or 3 weeks ahead on your Cabbage. Early or late varieties.

$15 \mathrm{c}$ doz.; $\$ 1.00$ per 100 . Postpaid.

EARLY CABBAGE PLANTS-For delivery in April and May. 50c per 100 ; $\$ 4.50$ per 1,000 .

LATE CABBAGE PLANTS-Ready for shipment in May and June. 45c per $100 ; \$ 3.50$ per 1,000 .

CAULIFLOWER PLANTS - April. 25 c per dozen; $\$ 1.50$ per 100 .

CELERY PLANTS-60c per 100; $\$ 3.50$ per 1000 .

SAGE PLANTS-25c doz. Postpaid. ASPARAGUS - ROOTS - 25c doz: $\$ 1.50$ per 100 .

RHUBARB ROOTS-10c each; $\$ 1.00$ doz. Postpaid.

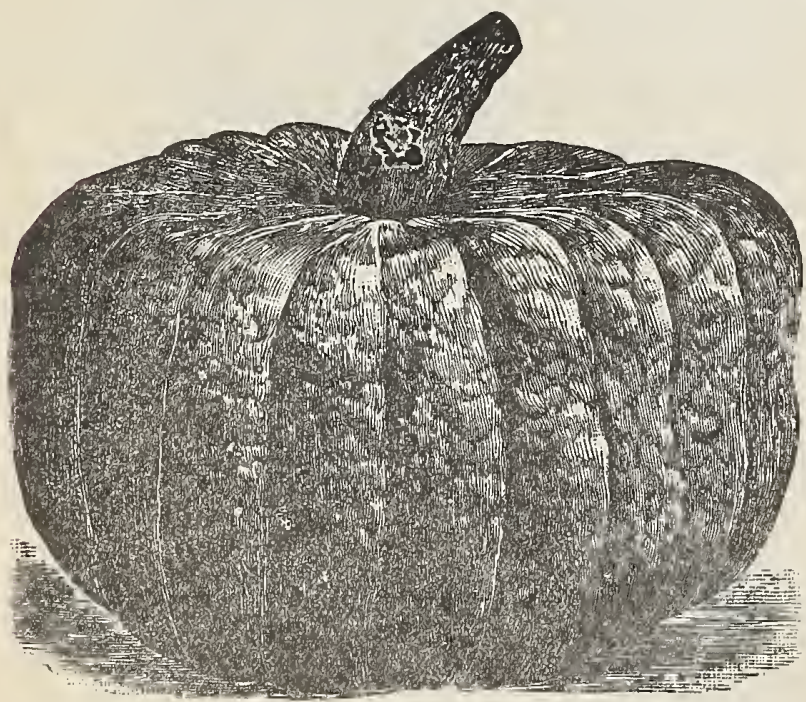

PUMPKINS

YANKEE PIE-The noted New England Pie or Small Sugar Pumpkin. Same shape and color as the Connecticut Field, but it is smaller, very sweet, fine grained and one of the pleases everyone for making pies. Pkt., 5e: oz., 15e: $1 / 1$ lb., 45e; lb. 1.25. Postpaiat.

ARGE SWEET CHEESE-A very large sized Pumpkin, often measuring 15 inches across top, flat like a cheese and very productive. It is an excellent keeper and is of the finest as for stock feeding, also largely used for canning. The skin is orange red. Pkt., 5e; oz.,

COMMON FiELD-The well known old Connecticut variety. Grows well among corn; varies in shape. Excellent for feeding dairy stock.

KING OW THE MAMNOTH-The giant among pumpkins. Often weigh over 100 pounds. Salmon skin. Flesh bright yellow, fine grained and of good quality. Pkt., 10e: oz.,

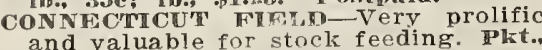

TENNESSEE SWEET POTATO-Pear shaped, skin and flesh a creamy white. Flesh thick and when cooked resembles sweet potatoes. Keeps $1 / 4$ lb., 50e: 1b., \$1.50. Postpaid.

KENTUCKY FIELD-A large variety, producing pumpkins in abundance Has thick meat and of fine quality. Very suitable for canners' use. Pkt. 5e; oz., 10c; lb., 50c. Postpata.

JONATHAN-Large, bottle shaped with a crook neck. Very prolific, flesh a good keeper. Pkr., 5e; oz.., 15e; 1/a lb., 35e; lb., \$1.50. Postpaid.

WHITE CUSUAW-Crooked neck with a hard creamy white shell. Thick flesh of excellent quality. Very
popular. Plat., 10e; oz. 15c; 1/4 lb. popular. Plet., 10e; oz.,

JAPANEE PIE-This is similar in size and form to the well known $\mathrm{Cu}$ shaw, but the skin is deep green. arker stripes turning to yellow as fruit ripens; earlier than other Pumpkin. Seeds marked with curious indentations. Flesh is very swek, a rich crimson eolor, dry an egos. rkt.. 5e: 0z... 15c; 1/4 1b.. 45e ih, eror Postromid.

\section{SALSIFY}

VEGETABLE OYSTER

ox. to mift. Drill libs, to One Acre in taste and flavor and is very nutritious. A most palatable vegetable; the cultivation is precisely the same as for Parsnips and Carrots. Salsify will keep through the winter, in the ground, in exactly the same manner as Parsnips. The has touched them. When cooking, boil the roots: when cold, mash, and fry as patties or fritters. This vegetable is also good stewed, plain boiled, and also as a salad, sliced raw in light, well-enriched soil. If it is necessary to use manure it should be very fine and well-rotted. Sow early in drills inches apart in the drills.
MARMOTH SANDWICH ISLAND-This splendid variety grows to fully double the size of the old sort: is of superior quality and delicate flavor. Is one of the most nutritious and delicious vegetables, and should be more generally cultivated for winter use when the supply of really good verables is limited. Roots white, smooth, enormous size, and of superior quality. Pkt., 10e: 25e: $1 / 4$ 1h., 75c. Postmaid.

LARGE WHITW-A common variety Roots medium size, smooth. White flesh. Plat., 10e; oz. 20c; $1 / 4$ 1b-, 65e. Postpaid 
RADISH 2 to 3 ox. to 100 ft. Drill CULTURE-Sow in ground, weil enriched with rotted manure. Quality depends on quickness of growth. The proper temperature is 40 to 65 degrees. Good ventilation is necessary if grown under glass. Sow seed $1 / 2$ inch deep in the early spring in rows 12 to 18 inches apart, for a Thin to 1 inch apart fo small varieties and 3 to 4 inches for the large varieties. Radishes will mature in from 3 to 5 weeks. Our French Grown stock of Radish Seed is the best that can be secured. Grown by the Best French Growers who have made a life study of the Radish and its habits. We can offer nothing better. tip quick growth. A favorite with market gardeners. Pkt., 5c: o\%., 10c; 1/4 1h., 25e. Postpaid.

\section{Our Superior Radish "The Fire Ball" Distinct-Attractive-Attains Very Large Size FIRM FLESH-TENDER AND BRITTLE}

Double the size of any of the turnip varieties. This radish de velops to 5 and often 6 inches in circumference, weighing often 1 oz. to the bulb-but notwithstanding its large size does not get pithy or hollow, but remains solid, tender and brittle. Shape round to oval and deep crimson in color. Excellent both for forcing and for open ground planting. Pkt, 10c; Oz., 20c; 1/4 Lb., 50c;"Postpaid.
TIE ICICLE

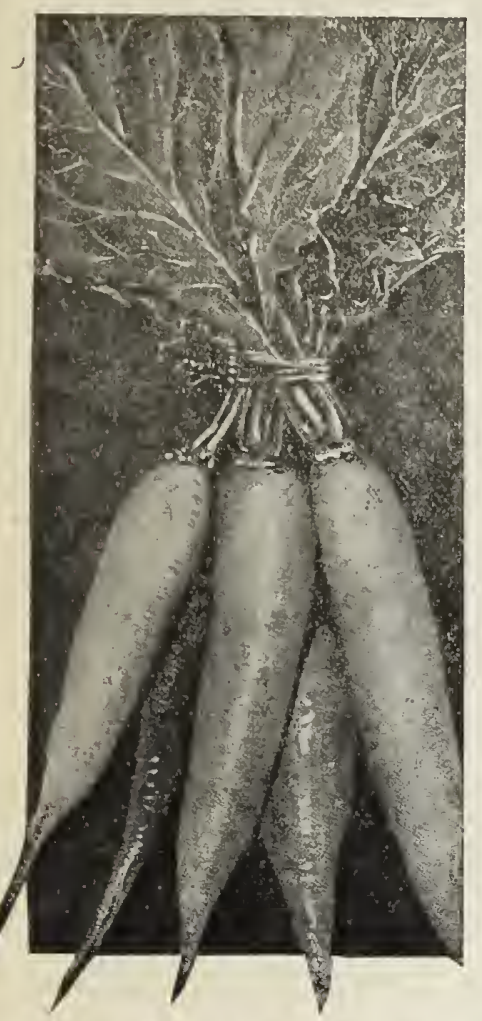

EARLY SCARLET TURNIP, WHITE TIPPEDWOlkCIN( - A beautiful variety, bright scarlet with white tip. Very nearly as early as Non Plus
Ultra, has a small top and may be planted as closely. It is most attractive in appearance and cannot fail to give satisfaction as a forcing Radish. Very popular as a market sort. Sold some5e; oz.. 10e; $1 / 4$ lb., 25c. Postpaid.

THE NEW PONDEROSO-Double the size of any of the early turnip-shaped type. This variety develops to 5 and often 6 inches in circumference times the weight of similar sorts: but notwithstanding its immense size, does not get hollow or pithy, the flesh remaining sparkling white, solid crisp and juicy, and of the mildest flavor. The col of the skin remains quite constant. Excellent botl for forcing and for open ground culture. Pkt. 10e: oz. 15e: 1/4 lh.. 50c. Postpaid.

CRIMSON GIANT FORCING-The most profitable variety for market gardeners and may well be considered the most valuable new variety which has been sent out for many years. A rapid growing sort, developing roots of beautiful deep double the size of any other forcing variety. The old standard sorts, such as Rosy Gem and inches in circumference, while the crimson Giants often measure 9 inches in circumference, without getting pithy or hollow, and retains its 15e; $1 / 4$ 1b., 40c. Postpaid.

ICICLE-The finest, most delicate and tenderest of pure white varieties. About 6 inches in length, clear transparent white, crisp and tender, very Ready to pull 3 weeks after sowing. May be sown as early in spring as soil can be prepared. Remains tender and free from pith for longer period than other sorts. This, with its attractive appearance and extreme earliness, gives it the foremost place among the Paris rest
Pkt., 5c; o\%., 10c; 1/\% lb., 25e. Postuaid.

FRENCH, BREAKFAST-Handsome variety of about 2 inches long. Pkt., 5c; oz., 10e; $1 / 4$ lb.,

HALF LONG DEEP SCARLET-Same form as Long Scarlet, but only half as long. Pkt.. 5e: oz., 10e: 1/4 lb., 25e. Postpaid.

IARKET GARDENER'S LONG SCARLET-A variety more largely used, perhaps. than any other for outdoor planting. Growing 6 to 8 inches in length, and possessing all the qualities of a fine Radish. Pkt., 5e; oz., 10c; 1/4 1b., 25e. Postpaid.

IMPROVED CHARTIER-(Scarlet White Tip.)" A distinct exceedingly handsome and attractive sort. Color of the top is scarlet rose, shading into pure white at the tip. Attains a large size before it becomes unfit for table. Undoubtedly the best all seasons Radish for the open ground. Ready for use or market as early as Long Scarlet, and keeps crisp and tender for two months. Planted late it makes a good winter keeper. Pkt., 5e; oz., 10e; $1 / 41 b ., 25 c$. Postpaid.

LONG WHITE VIENNA OR LADY FINGER-One of the finest and most popular of the long Radishes, growing 6 to 8 inches in length, beautiful in shape; skin and flesh pure white. Pkt., 5c; oz., 10c; 1/4 lb., 25e. Postpald.

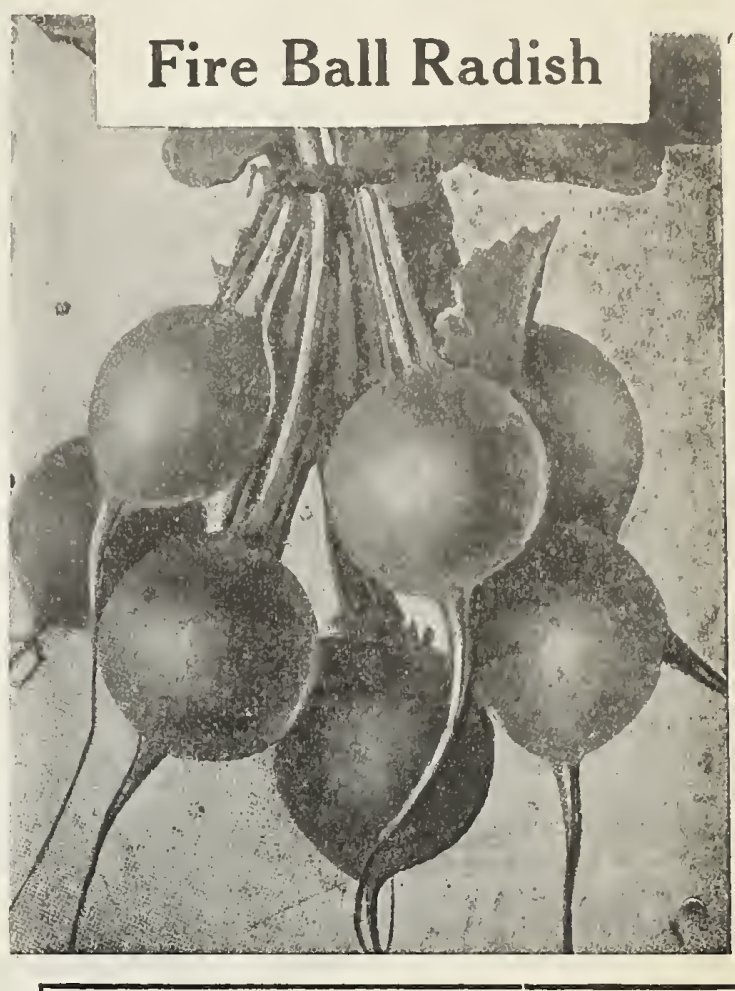

WINTER RADISHES

sow in June and Jaly

CALIFORNIA MAMMOTH WHITE-Pkt., 5c; oz., 10e; $1 / 4$ lb., 25e. Postpaid.

ROUND BLACK SPANISH-PKt., 5e: oz., loc: $1 / 4$ lb.. 25\%. Postpaid.

LONG BLACK SPANISH- $\cdots ; o z ., 10 \mathrm{e} ; 1 / 4$ lb., 25c. Postrif.

ROSE CHINA WINTER-Pkt., 5e: oz., 10e; 1/4 th., 20r. Postunid.

\section{SQUASH}

THE DELICIOUS SQUASH

For Both Summer and Winter Use. Deliciously Dry, Sweet and Rich. Wonderfully Prolific.

DELICIOUS-The best flavored Squash in existence. For table quality there is no other Squash that can be compared in sweetness and richness of flavor. It is an excellent Squash for fall as well as for winter use, keeping well until late in spring. The fruits are of medium size, usually weighing from 5 lbs, to $10 \mathrm{lbs}$. The rind is dark green, mottled in lighter shade. The flesh is very fine-grained, thick and dark orange in color. Pkt., 5e oz., 15e; 1/4 1b., 35e; 1b., \$1.50. Postpaid.

MAMMOTH WHITE BUSH-Of all round scallop or patty pan Squashes, this is the very best; but not quite so early as Early White Bush, but far superior in size and quality. Sometimes known as vegetable marrow. Fruits round, white, deeply scaland delicious.
LARGE WARTED HUBBARD SQUASH-A very large strain of the famous Hubbard, retaining all the excellent features of the parent, with the additional merits of thicker flesh, finer color, increased size, better constitution and productiveness. It has an extremely hard, tough and denselywarted shell, one of the best winter keepers. (See cut.) Pkt., 5e; oz., 10e; 1/4 1b. 35c: $1 \mathrm{~b} ., \$ 1.50$. Postbaid.

MAMMOTH SUMMER CROOKNECK-PKt. 5c; oz.. 10c; 1/4 lb., 35c. Postivaid. WINTER CROOIKNECK-Pkt., 5e; oz.. 10c; 1/s H... 25m. Postbaid.

HUBBARD SQUASH-This old and popular favorite is still one of the very best Winter Squashes grown; flesh deep golden yellow and fine-grained, and whether boiled, steamed or baked, it is always richly flavored, sweet and dry: The vines are strong and of luxuriant growth and very productive, yielding large, heavy Squashes of dark.bluish-green color, welghing often 10 to 25 pounds each. Properly stored, it may be kept from September to 


\section{TOMATO SEED}

1 oz. to 2,000 plants.

Set 3 feet apart takes 4,840 plants per acre.

Set 4 feet apart takes 2,723 plants per acre.

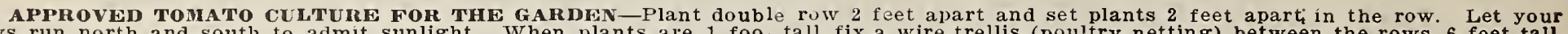

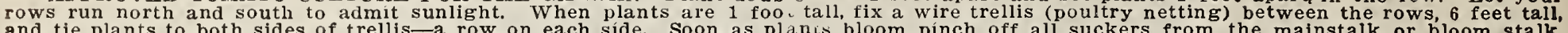

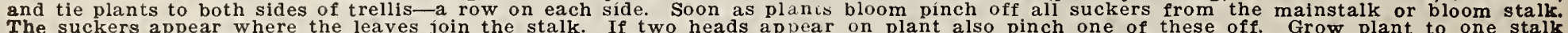

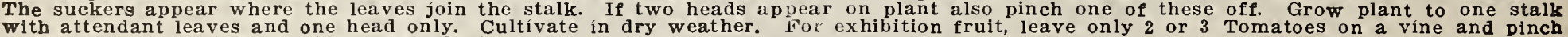
top of vine when fruit is size of Hazelnut.

Onr Improved Tomnto seed is grown strictly for seed purposes only, the

JUNR PINK-Ripens as early as Spark's Earliana and 10 days to 2 weeks earlier than Chalk's Early Jewel. It is an enormous bearer, clusters of 6 to 10 fruits being borne at the crown and at the forks of the branches. The fruit is of medium size, uniform, smooth and attractively shaped, without cracks or any green core. It will average $23 / 4$ to 3 inches in diameter and 2 to $21 / 2$ inches in depth. The skin is reasonably tough, so that it is excellent for shipping. In color it is a bright, pleasing pink, and in markets where a pink Tomato is desired it will bring 25 per
cent more in price than any red variety. Pkt., 10c; oz., 35es $1 / 4$ cent more in price th.

EARLIANA-This is without doubt the earliest bright red Tomato now in cultivation. The Tomatoes are deep scarlet and grow closely together in clusters smooth and solid. The plants are quite hardich drarf habit of dwarf habit of grow not much space can be wasto a m variety. It is especially valuable as it produces fruit at the time when the prices are the highest, No market gardener
without it. Pkt., 10c: oz., 30c; $1 / 4$ lb., 75c. Postpaid.

DWARI CHAMPION-Dwarf and compact: stands straight up with thick, short jointed stems, and on this account it is very valuable, as it can be planted exceedingly close and still leave plenty of room to gather the fruit. An extra early sort and therefore valuable to market gardeners, as the first Tomatoes in the market always command the highest price. The fruit is of purplish pink color, round and smooth, greatly resembling the Acme; flesh very solid and

PONDEROSA-Not only the largest fruited Tomato grown, frequently weighing 2 to 4 pounds each, but the handsomest and
finest in quality; almost as solid as beefsteak, nearly seedless, with firm, meaty rich red flesh, unequalled and delicious either sliced, cooked or canned; a healthy, luxuriant grower, prodigious and continuous yielder from early in the season until frost. Pkt. 10e; oz., 50e: $1 / 4$ lb., $\$ 1.50$. Postpaid.

TRUCKER'S FAVORITH-A purple fruited sort of excellent quality highly esteemed in many eastern markets. Grows to uniformly large size which is maintained until late fall. Fruits are invariably smooth, solid and the flesh is of finest color throughout. from rust or blight and bear continually until killed by frost. Fkt.. 10e; or., 45e; 1/4 lb.. \$1.00. Postpaid.

CHALK'S EARLY JEWEL-Within a week to 10 days as early as the famous Spark's Earliana, it is even a heavier cropper, with Tomatoes of larger size and sweeter flavor, while its more robust browth makes it a surer cropper. Large, handsome fruits, very solid, deep through. Color brightest scarlet, ripening right up to the stem without any cracks or green core. The foliage is rather open, admitting the sunlight to the center of each plant, so that all the fruits are thoroughly ripened, Flesh thick, bright scarlet, solid, with comparavitely few seeds and of sweet flavor; skin thin. but strong enough to make a good shipper. Pkt, 10e; ox., 40e; $1 / 4$ lb., \$1.00. Postpaid.

FA VORITE (LIVIN'STTON'S)-Ripens evenly and early, holding its size to the end of the season; very profilic; good flavor, few seeds, flesh sound. Pkt.. 10e: oz.. 20e: 1/a lb., 60c. Postpaid.

PERFECTION (LIVINGSTON'S)-Larger than the Acme; color blood red; it is onfe of the first to ripen; almost round in shape, perfectly smooth and very solid of the best quality;

BEAUTY (LIVINGSTON'S)-A very fine variety of large size; grows in clusters of 4 or 5 ; color glossy crimson with a purplish tinge. Very solid, with a tough skin, making it a desirable market varíety. Pkt.. 10e: oz., 35e; 1/4 lb., 75e; lh., \$3.50. Postpald.

\section{SUNRISE TOMATO}

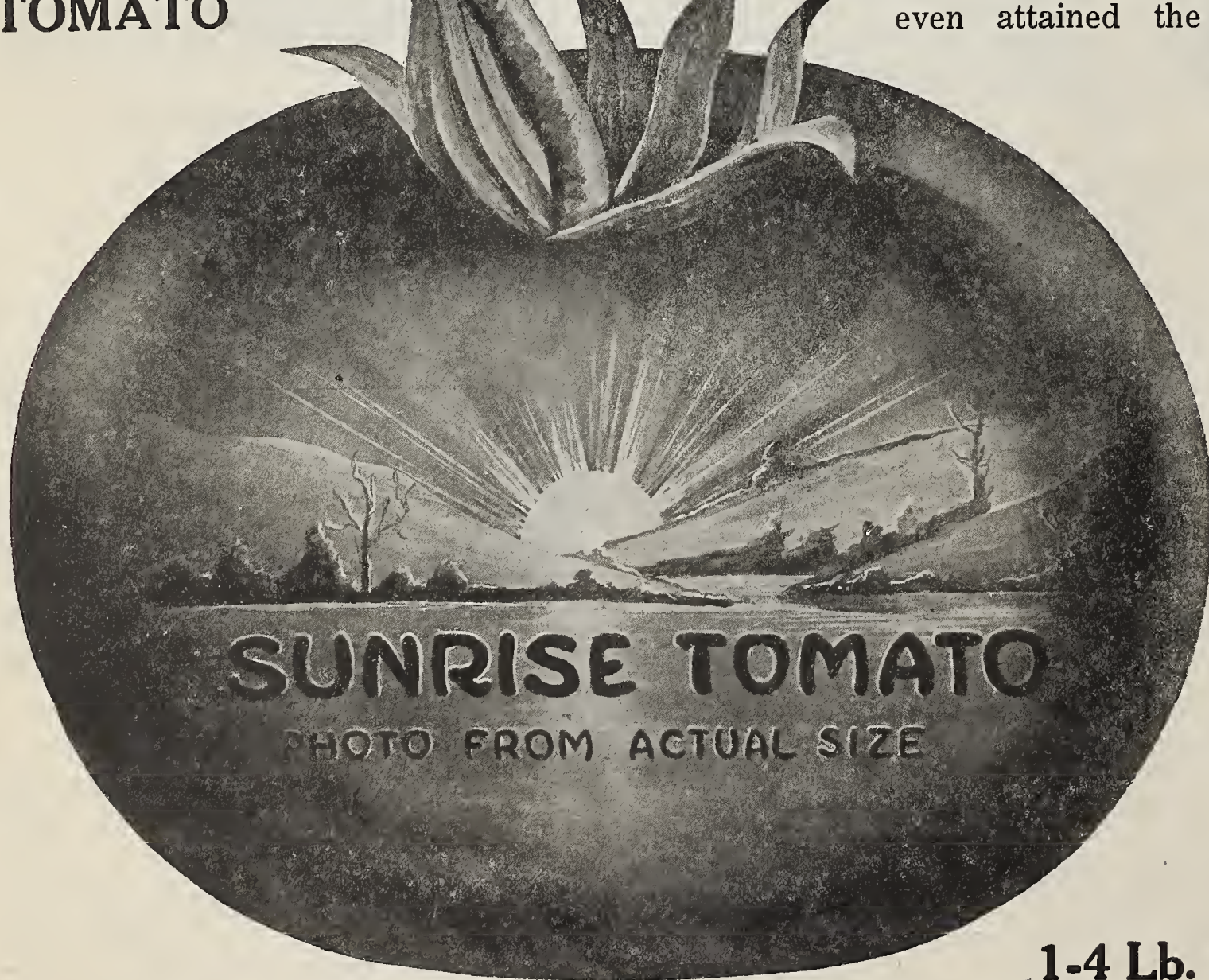

No other variety has ever equaled or even attained the same class as the SUNRISE. Large in size, deep crimson in color, solid in meat, and the most delicious flavor ever found in a tomato. Very small seed cavity, and one of the most abundant producers ever grown; ripens very early; some have be e $n$ picked by July 15th, and bear until frost. Vine should be tied up for best results.

\section{PRICE}

Pkt., 15c; 0z. 40c; 
CRIMSON CUSHION-Of immense size, 1 to pounds each; smooth, almost seedless and solid as beefsteak; a prodiglous and crimson scarlet: quality meaty and superb either sliced or cooked. Pkt., 10es oz., 50c: 1/4 1h., \$1.50. Postpald.

GREATER BALTIMORE-Just double the yield of many of the best cropping tomatoes you have ever grown. Smooth, well formed and deep from stem to blosto its firmness and great meatiness. It ripens evenly to the stem and is entirely free from ridges, cracks and blight. Brilliant red color. Pkt., 10c:

ACME-The Acme is one of the best early tomatoes that we list. The vines are large, hardy and productive, ripening its first fruit very early and continuing to bear abundantly until cut off by the frost. Fruit is purplish pink in color and is round, smooth and of good size. free from cracks and stands shipping weli. Flesh is solid and of excellent flavor. Pkt., 5es oz., 35e; 1/4 lbo \$1.25; Ib., \$4.00. Postprid.
JOHN BAER-An extra early scarlet frulted Variety of superior merit. The vines are very hardy and exceptionally productive. The fruits are the largest of the extra arly sort and are also most attractive in firm and of are nearly round, smooth, of the earliest to ripen and it continues to furnish marketable fruits much longer than any other very early variety. It is an invaluable sort for market gardener

BEEFSTEAK TOMATO is the best, great big, main crop tomato for the home garden that grows. It is nearly as large as the Ponderosa but is more round in shape and of bright scarlet color. It is an exceptional smooth tomato to be of such large hard cores that are so frequently found in tomatoes of this size. The fruits are very large. nearly round, very thick and meaty with but few seeds. Its fine meaty large size makes it a wonderful variety for home use. Beefsteak Tomato will more oz., 50e; $1 / 4$ lb., \$1.50. Postpald.
MATCHLESS (NRIGHT RED)-One of the best main-crop tomatoes. The solidity, absence of core, size and color of fruit, together with its freedom from rot, all unite in making this well worthy of the name of "Matchless." Always large, even at the end of the season. Fine both for the private and market garden and canning. The Matchless is what we would call thoroughly dependable tomato. Pkt oz., 25e: $1 / 4$ lb., 80c. Postpald.

TOMA'TO PLANTS-Ready after March 16th. Bonny Best, Earliana, June Pink, Beauty, Acme, Stone and Ponderosa. As it is not possible to have all the varieties at the right size for shipping, please give us a second choice for Early plants.

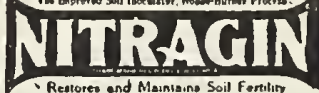

PPECIAL TO CANNERS WRITE

BONNY BEST-Or about the same season as Chalk's Jewel, but they average somewhat smaller. They are of bright scarlet color, very smooth and of remarkably uniform size and shape. An elegant one for market and shipping on account lb., \$1.00. Postpaid.

GOLDEN QUEEN-Fruits large and smooth; color a beautiful golden yellow, sometimes with a slight blush of red, as smooth and well shaped as the best of the RED RoCK-A great big red, meaty Tomato the best of the late maturing vaRED ROCK-A great big red, meaty Tomato, the best of the late maturing vahas no superior in texture and flavor and is red as a tomato can be all the way has no superior in texture and flavor and is red as a tomato can be all the way from 110 to 115 davs. Pkt., 10c; oz., 15e; 1/4 lb., 50c. Postpaid.

NEW STONE-Unquestionably the best general crop Tomato in cultivation for the home garden and for the canner. For the market gardener it stands withou a peer. For several years we have made a specialty of our New Stone Tomato with remarkable success. Our strain this seasoh is the same as heretofore. We feel assured of the patronage of those who have used our New Stone, and would ask those who have been buying elsewhere to give us an opportunity to make
you prices. Write for special prices in large quantities. Pkt., 10c: oz., 26e: $1 / 4$ lb., 75e. Postpaid.

DWARF STONE (LIVINGSTON'S)-In hablt of vine it resembles Dwarf Champion, but is of stronger growth and more erect. The fruit resembles Livingston's Stone in color, shape, and, what is more remarkable, it is almost the same in size. The Dwarf Stone is fully double the size of Dwarf Champion and yet Canners write for special prices in quantities on Tomato Seed.

SMALX FRUITED AND PRESERVING VARIETIES

These are easily grown, immensely productive and very delicious for preserves. The seed has all been grown on Fordhook Farms and, like all Fordhook specialties, is the best that can be produced.

TeLLow PLUY-Size and shape just like a plum; of a bright lemon-yellow; fleshy and of excellent flavor. Very much used for marmalade. Plet., 10c; om. roc. Postpald.

YELLOW PEAR TOMATO-This is an attractive small-fruited tomato of typlcal pear shape. The plants are enormously productive and the small fruits make excellent salad or may be us

FLLOW CHRRY - The small yellow fruits are borne in clusters, each fruit averaging half an inch in diameter. Pkt., 10c: oz., 40c. Postpald.

PEACH-The fruits average $1 \frac{1}{2}$ inches in diameter. The skin is covered with a 作 slight bloom or pubescence,
Pkt., 10c; oz., 35c. Postpaid.

RED CHERRY-Attractive small fruits of a bright scarle and fine for marmalade. Pkt., 10c; oz., 45e. Postpaid.

RED PEA-The fruit is bright red, of true pear shape. Rich and distinct in

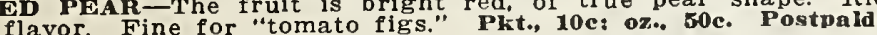

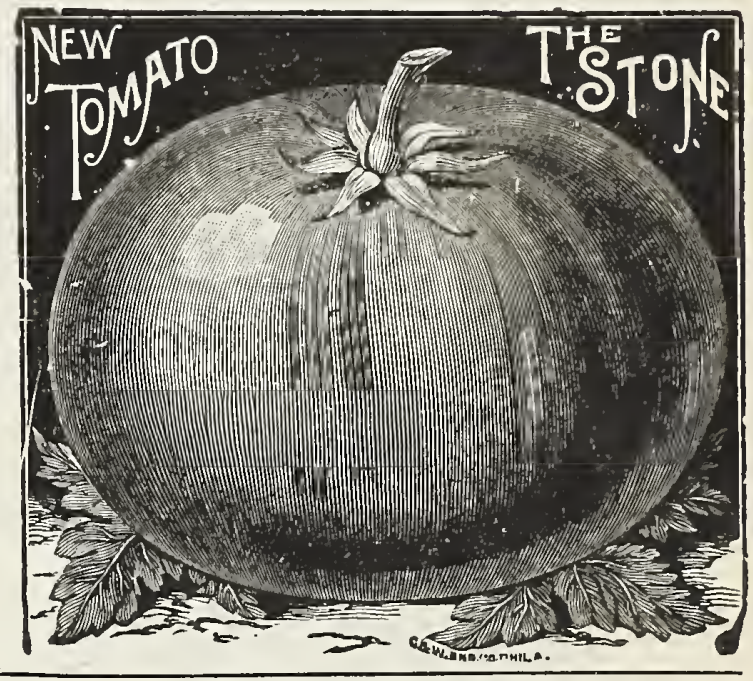

PIMENTO

So popular has become the Pimento that delicious Pimento concoctions too numerous to mention have sprung up all over the country. Used in salad it is highly ornamental to the eye, and delicious to the palate. Its thickness of flesh permits removing of skin, an with other sorts. large as Chinese Giant, but owing to thick flesh, weighs more. It has qualities vastly superior to any other pepper and can be utilized in almost every conceivable table diet. Ours is a specially selected seed. Pkt., 5c; oz., 40e. Postpaid.

\section{P E P P E R}

CULTURE-Peppers should be started in a hot bed in February or March, and not planted outside until the ground is warm and there is no more danger of frost. Set the plants in rows 2 feet apart and 18 inches in the I oz. produces about 1,000 plants.

CHINESE GIANT-Absolutely the largest red variety. Not only is it early in ripening and immensely productive for so large a Pepper. but its enormous size will cause it to sell most readily. The monstrous fruits are of thick, blocky form, and of most brilliant, glossy scarlet. They grow 4 to 5 inches broad at the top, are of equal length, divided into 4 or more large ridges. The flesh is extremely mild, and unusually thick; it makes an excellent salad sliced and served like tomatos, 10c; 1/4 oz.. 15c; 1/2 oz.0 25e oz.. 50e. Postpald.

SWEET MOUNTAIN-Similar to Bull Nose, but larger and milder. Pkt., 5c; ox., 35c; $1 / 1$ lb. \$1.35. Postpald.

GOLDEN DAWN-A mild and sweet yellow Pep per. Very attractive. Pkt., 5e; oz., 35e: $1 / 4$ lb., \$1.35. Postpald.

LARGE RED CHILE-Used in flavoring Chil
Con Carne, a dish that is so popular in restaura.

BULL vosE-This is one of the old standard Mango Peppers; very early and mild. Ligh green in color, turning to bright red when left on the bush. It is used extensively for salad.

RUBY KING-Large handsome variety Rub red in color and growing 4 to 6 inches long. RED CLUsTer-Small and top of stalk. Pkt., 5e: ox., 40c. Postpaid.

NEAPOLITAN-Two weeks earlier than the Bull Nose. Fruit of good size, growing on a stalky plant The flesh is quite thick and mild; color light green turning to bright red when ripe. It is a favorite for market on account of its earliness. Pkt., 10e; oz., 50c. Postpaid.

SMALL CAYENNE-Dwarf growing Pepper Very hot and used for seasoning and in pepper sauce. Pkt., 10e: oz., 35e. Postpald.

LONG RED CAYENNE-Cone shaped red pods. Used largely for sauces and pickles. Pkt. 10e; nz., 35e. Postpaid.

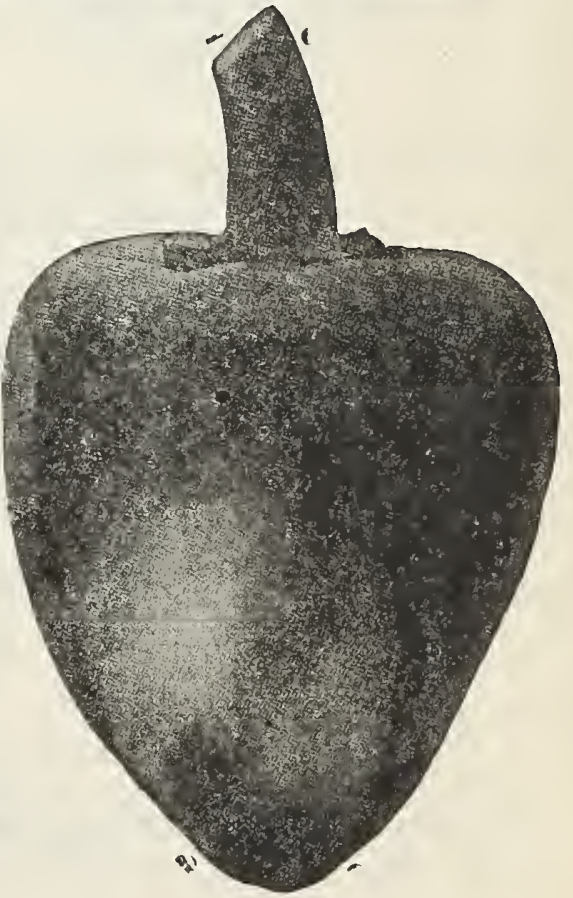




\section{TURNIPS}

CULTURE-One ounce will sow 150 feet of drill; 1 to $1 \frac{1 / 2}{2}$ lbs. to the acre. For the early spring and summer crop, get them started as soon as possible, so they may have grown to sufficient size before hot weather. For the main crop sow the middle of July to the last of August. For feeding stock in fall or winter there Turnips and Ruta-Bagas, as they yield a larger amount of food than anything else

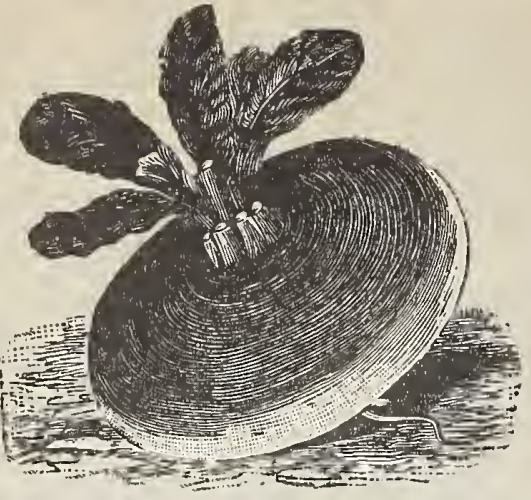

EXTRA FARLY PURPLE TOP MILAN-The earliest in cultivation, two weeks earlier than Purple Top, Strap Leaf. Bulb is flat, of medium size, quite smooth, with a purple top. Flesh white, hard and of finest quality. It is an extra good keeper. Plkt., 10e; oz., 15e: 1/4 1b., 35e: 1b., \$1.00. Postpaid.

EXTRA FARLY WHITE MILAN-Variety remarkably early. Tops very small, strap leaved, upright and compact. Roots clear white, very smooth, flat and are of best quality when only about 2 inches in diameter. Flesh clear white, mild, sweet and tender. Pkt., 10c; ox., 15e; $1 / 4$ lb., 35e; lb., \$1.00. Postpaid.

POMuranean White GLOBE-One of the most productive kinds, and in good. rich soil roots will frequently grow to 12 pounds in weight. It is globe-shaped or slightly flattened; skin very white and smooth. Used for stock feeding, also good for table use if pulled when the roots are not more than 4 or 5 inches in diameter. Where the winters are mild the tops are

YELLOW ABFRDELN-Excellent for feeding cattle. Pkt., 5c; oz., 10e: $1 / 4$ lh., 20e: 1b.. 75e. Postpaid.
PUIRPLE TOP STRAP LEAVED-This variety has a reputation for dependability regardless of soil or climatic conditions. Its mild sweet, fine tempered flavor has made it popular for table use. It is a turnip that seems in every way to satisfy. For home garden or market purposes it is equally popular. It has no superior for early spring and late fall sowing, producing in about six weeks' time a usable, tender, mild, sweet turnip. The leaves are short, the roots quite flat with the upper half a purplish color and the lower half white. The flesh is pure white, crisp and finely grained. It grows very rapidly from the very start. Pkt., 5c; oz., 10c; 1/4 1b., 20c; 1b., 60c. Postpaid.

PURPLE TOP WHITE GLOBE-This is one of the handsomest and most salable Turnips. Very desirable for either home or market gardens. It is a large, rapid growing sort, wtih globular shaped rots. Site the top bright purple. out yield any other sort and is always a sure cropper. Pkt., 5es out yield any other surt, and is always

LONG WHITE, OR COW HORN-Grows partly above ground. Very prosed and of excellent productive. Flesh white, fine grained, sweet and of excellent quar GOLDEN GLOBE-One of the best varieties for a field crop for stock. Flesh yellow, fine grained and sweet. Pkt., 5c; oz., 10c; (1)

SEVEY TOP-Cultivated extensively for the tops, which are used for greens. It is hardy and will grow all winter, but does not for greens. It is hardy and w only recommended for the tops. Pkt., 5e; oz., 10e; $1 / 4$ lb., 20c; 1b., 60e. Postpaid.

EARLY WHITE EGG-An egg-shaped variety for

spring or fall sowing. Flesh white, firm, fine lb.. 25e: 1b.. 75c. Postpaid.

GARLY WHITE HEAT DUTCH-(Strap Leaved.) Matures only a week after the earliest Milan, but keeps much longer in fine condition. The skin is pure white, the flesh is mild, juicy and of the best table qualities. Pkt., 5c; oz., 10e; $1 / 4$ 1b., 20e: lh., 60e. Postpaid.

WARIY SNOWBALL (EXTRA EARLY)-This is a small white globe, very quick, earliest in maturity of its form and character. We highly recommend it for table purposes. Pkt., 5e; oz..

10c; 1/4 lb.. 20e: lb., 60e. Postpaid. feeding stock. Pkt., 5e; oz., 10e; 1/4 lb., 20c; 1b., 75c. Postoaid.

\section{RUTA-BAGAS RUSSIAN TURNIP $_{\text {SWIIS }}^{\text {OR }}$}

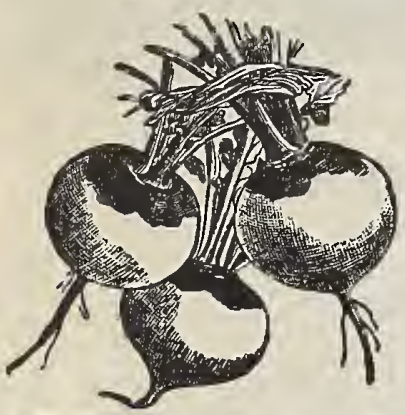

SKIRVINGS'S PURPLE TOP-A.ttains an immense size. Fellow flesh, fine flavor tious. Pkt., 5e; oz., 10e; 1/4 1b., 15e; lb., soc. Postpaid.

AMERICAN PURPLE TOP-For years a great yielder and unsurpassed for stock sweet and of the richest very large, sc; oz, 10c; 1/4b., 20c; 1b. 65e. Pkt. paid.

IMPERIAL HARDY SWEDE-Grows to a large size with a single tap root and produces a fine bulb, always of good quality, and is one of the best for winter use. Pkt., 5c; oz., 10e; 1/4 1b., 20e; lb., 65e. Postpaid.

Write for prices on lots larger than WHITE RUSSIAN, OR LARGE WHITE RUTA-BAGA-Grows very large, excellent for table or stock. Flesh firm, white and solid. Has a very rich and sweet flavor; the best keeper of any. Pkt., sc; oz,
loc: 1/4, lb., 20c: lh.. Asc. Postnaid.

\section{KOHL RABI}

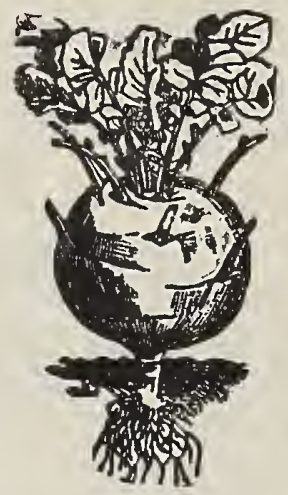

The edible part is the turnip-shaped bulb ormed above ground. It is tender and excellent when used before fully grown, combining somewhat the flavors of cabbage and turnip. Seed should be sown in light, rich 11/ as early in spring as possible in row thin to 6 inches apart in the row. ings at intervals of 10 days will plantsuccession until hot weather, when they fail to grow well. Plantings may be made the latter part of July for fall use. One ounce of seed sows 200 feet of drill.

EARLIES WHITE VIENNA-Greenish white utside, with clear white flesh within. gmooth, short laf. in quality. Pkt., 5e; oz., 20c; $1 / 4$ lb., 50c. Postpaid.

EARLIEST PURPLE VIENNA-Same in every respect as the Earliest White Vienna, except in the outside color. Pkt., 5e; oz., coc: 1/a lb., 50c. Postwaid.

\section{SUPERIOR LAWN SEED}

\section{An All Green Stay Green Lawn is Hard to Secure But When You Have Produced One From Our Su- perior Lawn Seeds You Will Be Convinced That It Can Be Done.}

Too much care cannot be taken in preparing the yard for a good lawn. The essentials for a fine lawn are: First, good drainage; second, prepare the soil to a good grade and work it up to a fine and smooth condition; put plenty of manure on and water regularly, if there is not sufficient rainfall. Lawns made up and sowed with our SUPERIOR LAWN SEED produces a fine, velvety lawn which is a beautiful dark green and stays green the year around. We recommend our special Sheep Guano Lawn Fertilizer for this purpose, as there is no weed seed in it. Use 100 pounds for lot $40 \times 50$.

Price for Lawn Seed, 1 lb., 50c; 5 lbs., \$2.25; 1/2 bu., \$4.00. Post-paid.

Price for Fertilizer, 50 lbs., $\$ 1.60 ; 100$ lbs., \$2.75, not prepaid.

One pound sows 350 square feet; 3 pounds sows 1,050 square feet; 5 pounds sows 1,750 square feet; 10 pounds sows 3,500 square feet; 15 pounds sows 4,250 square feet. Use about one-half the amount for renovating old lawns. Write for special prices on large quantities.

\section{Bermuda}

Per lb., 50c; 5 lbs., \$2.25. Postpaid.

\section{Kentucky Blue Grass}

Per lb., 50c; 5 lbs., \$2.25. Postpaid.

\section{White Dutch Clover}

Per lb., 85c; 5 lbs., \$4.00. Postpaid.

REEDS AND RAFFIA-Special sizes and quality for high class basket work. Raffia Natural, oz., 15c; 1/4 lb., 25c; lb., 85c. Colored, oz., 20c; 1/4 lb., 65c; lb., \$1.65. Reeds, 8, 10, 12, 16 ft., oz., 15c; 1/4 lb., 50c; lb., \$1.75. Postpaid. 


\section{WATER MELONS}

CULTURE-Prepare hills 8 or 10 feet apart each way by workng in thoroughly rotted manure, or poultry dropplngs-rich ground gives the plants a good start before lnsects attack them. When he ground is warm plant 6 or 8 seeds to the hill, covering an inch deep and, when well us thin out, leaving three strong plants to insect remedies as recommended for cantaloupes.

\section{Our Valuable Premiums with every order will be appreciated by every one}

KLECKLEY SWEET-Familiarly known as Monte Cristo and a melon unsurpassed. Claimed by many to be the leading home garden melon at the present time. It is an extremely sweet, julcy, fine flavored variety. Fruits are falrly large, just the proper size, oblong shape, tapering somewhat toward the stem end, dark green color with slight inclination to russeting. Average 12 inches in diameter and 20 inches in length. Matures in about 8 days. The fiesh is very bright rich red. Unusually crisp and tender, in fact, so tender that it is, not recommended for rallway shipment, on account of its bursting open. The seed ls white. Pkt., oz., 10e: 1/4 lb., 25es lb., 60e. Postpaid.

LIGHT ICING. OR GRAY MONARCH-Skin mottled gray, flesh bright crlmson. Deliclous flavor. Shape long and very pro ductive. Pkt., 5c; oz., 10e; 1/4 1b., 25e; lb. 75e. Postpald.

ANGEL KISS-One of the earliest and best tasting melons in existence. It grows from medium to very large, very long in shape and nearly whlte in color, handsome and attractive. The flesh is the sweetest, tenderest, and the very deepest crimson we have ever seen in a melon. We do not hesitate to say that it is the very earliest good melon ln cultivation. The vines are robust and strong-growing. They should be planted fully 12 feet apart each way, often settlng fruit before runners are a yard long, and so prolific that you can almost walk across the patch on the Melons. One distinct feature of this Melon is that the flesh is a good deep red by the time the seeds are formed in it often before the Melon is really half grown. Seeds are very small and very the best Melon for home use that we know of, and feel sure that our customer will also say so after they have tried it Pkt., 5e; ox., 10e; 1/4 1b., 30e; 1b., \$1.00. Postpaid.

SNOW BOUND-A very large, oblong shaped Melon, often weighing 40 to 50 pounds each. Skin gray or a light green color flesh deep red, tender and sweet. It is a fine home Melon and a splendid shippins variety. Pkt., 5e; oz., 10c; $1 / 4$ lb., 30c: $1 b$. \$1.00. Postpaid.

KOLn'S GEM-Has no superior for shipping purposes. Fruit large, oval shaped. Medium size. Green striped with lighter shades. Pkt., 5e; oz., 10c 1/4 lb., 25e; lb. 75e. Postpaid.

DARK ICING-Shape oblong, rind dark green, flesh dark red and of fine flavor. Pkt.. 5e; oz., 10c; 1/4 Ib., 25e; 1b., 75e. Postpaid.

FORDHOOK EARLY-Extra early, fine quality and large size. Nearly round, skin green, flesh light red and very sweet. Plrt. 5e: 0z. 10c: $1 / 4$ Ih.. 25e: lb., 75e. Postpaid.

JONES' JUMBO-Solid green and flesh bright red. Sweet and juicy, immense size. Pkt. 5e; 0z., 10e; 1/4 1b., 25c; 1b., 75c. Postpait.
ALABAMA SWEET-This is a large oblong Melon; color dark green with faint lighter stripes. Being of good size though not ungainly, it is first-class for shipplng purposes. Its flavor is simply delicious, it is entirely stringless, and its outslde appearance is attractive. Its size and shape is such as to make it one of the best market Melons, and we cannot recommend it too strongly. Fancy selected Southern grown seed. Pkit., 5e; oz., 10e; $1 / 4$ lb., 25e; lb., 00 e. Postpaid.

RATTLESNAKE-This melon made Georgia famous as the finest melon-growing state. There are no finer melons grown than the Rattlesnake. 60 to 75-pound Rattlesnake melons are nothing unusual. Light green with dark green stripes; red meat, wlth white seed tipped wlth black. Pkt., se oz.. 10e: $1 / a$ lh., 25es lb., 60c. Postpaid.

COLE'S EARLY-A hardy sure cropper. Nearly round. Flesh dark red, rind thin and extremely brittle. Medium size. Green strlped with lighter shades. Pkt. 5e; oz., 10e; $1 / 4$ lb., 25e; Ib., 60e. Postpald.

GOLDEN QUEEN-A handsome, delicious Melon desired by some in preference to the red-meated varieties. An early, heavy ylelding, yellow or golden hearted Melon of rich, lucious, sugary flavor. It is nearly round in shape with a dark green rind with stlll darker green mottled stripes Vines are vigoroug and proliflc. Flesh golden, sugary, crisp, tender and coreless. Matures in about 90 days. Pkt., 10c; oz., 15e; $1 / 4$ lb., 40c; lb., \$1.25. Postpald.

RED SEEDED CITRON-A type of Melon used entirely for preserves, pickles, etc. The fruits are medium sized, uniformly round, of dark green color, striped with light green. The flesh is solid, white and sweet. The seed red. Matures late in the fall, requiring about 95 days. Will keep for long periods. Is not good for eating paid.

THE DIXIE-The size is large, specimens weighing 50 lbs, being not infrequent. The flesh is scarlet, very fine and extra firm. The rind, though thin, is of a good keeping quality. One of the best shipping melons grown, often producing on a melons, of a dark green oblong shaped lighter green. Black seed. Plit., 5c: os. 10e 1/4 1b., 25e: 1b., 60e. Postpaid.

PEERLESS-Also called Red-fleshed ree Cream. This is the melon that proved so a good shipper and a delicious is early Pkt., 5c: oz., 10e; 1/4 1h., 25e; 1b., 60e.
Postpaid.

MOUNTAYN SWEET-A large variety. Oblong in shape and of good size. Striped scarlet and deliciously sweet and a good shipper. Pkt., 5e; oz., 10e; 1/4 lb., 25e; lb.,
SWWET HEART-Early, large, oval, light green; rind thin but firm. Flesh bright red. Sweet and tender. A splendid shipper. Pkt., se; oz., 10e; 1/4 lh., 25e; lb., T5e. Postonld.

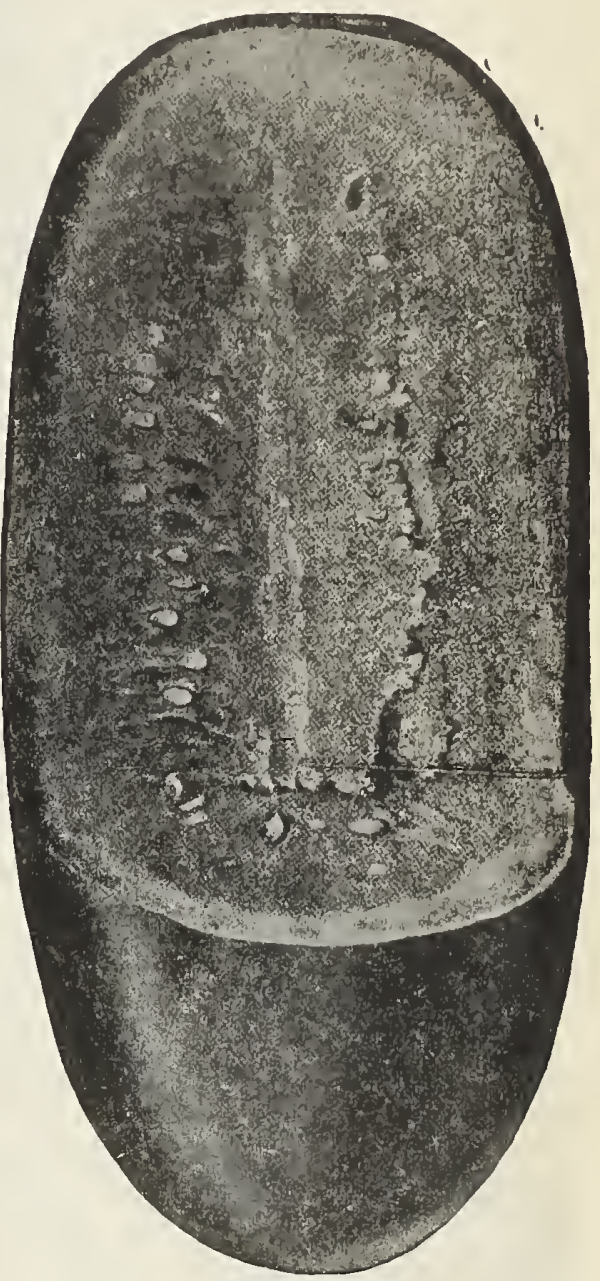

IRISH GREY - The size is uniform and large. Color of rind yellowish gray and almost as tough as that of the Citron. Ripens earlier than Watson and will keep in good condition for a long time after picking. Very prolific and a good shipper. A fine sort. White seed. Pkt., Je; oz., 10c: $1 / 4$ 1b., 35e; lb.. \$1.00. Postpaid.

VICO DUST-Keeps Bugs and Beetles from for prices.

\begin{abstract}
TOM IVATSON-A new variety destined to become a leader among Melons, because of quality and shipping excellence. There is no variety to our knowledge that combines both of these essentials enough to ship and most shipping Melons are too tough to excel in quality. The Tom Watson is a large, oblong Melon, the skin quite distinct from other varieties. It averages 18 to 24 inches long and 10 to 12 inches in diameter and weighs 50 to 60 pounds. The rind is thin but tough and flesh a hright, attractive red Seeds brown, tipped white. Pkt., 5c; ox., 10c: 1/4 1b., 25c: 1b., 85c. Postpaid.
\end{abstract}

BLUE GEM-Resembles Kolb's Gem in shane, hut better flavored. Strlpes more indistinct than Knlb's Gem. Cnlnr dark purplish
blue. Pkt., 5c; ox., 10c; 1/4 1b., 25e; 1h., 85e. Powtpald.

\section{Pick your Premiums, your selection 3 Packages free with $\$ 1.00$ order.}

FLORIDA FAVorite-Large, oblong, rind dark green with strlpe of lighter green. A popular variety in the South. Pkt., 5e; oz., HALBERT HONEY - The introducer describes this as equal in flavor and as handsome as the Kleckley's Sweets and much more productive. A long early melon, with dark, rich glossy green rind use and home market, but is too thin and brittle to stand ship

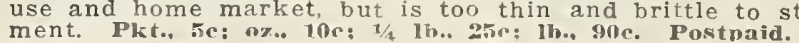

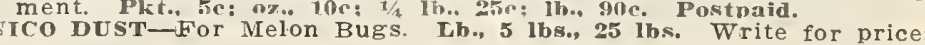




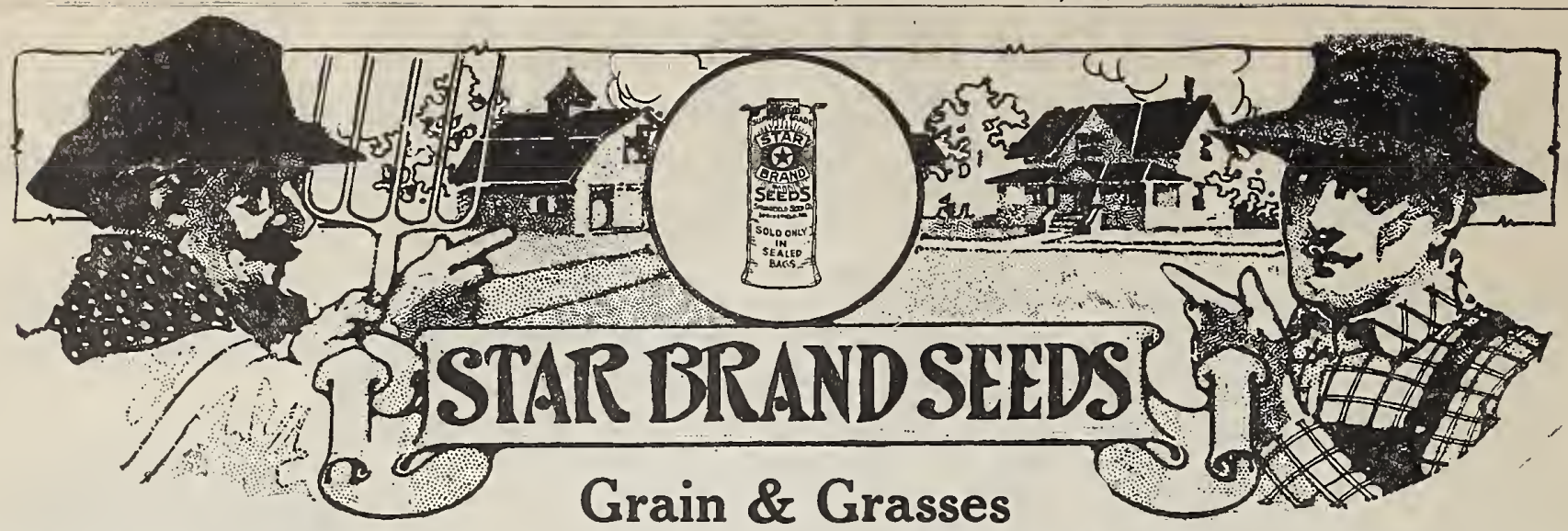

Sixty-four per cent of the meat consumed in the world is Beef. When one stops and considers this item alone he can realize how important it is for good pasture and a hay crop. You cannot raise good Beef if you haven't good feed. You can't raise good feed if you don't sow good seed. STAR BRAND SEED has been recognized by the farmers and planters for many years as the best to be had anywhere. Don't let price influence you. Insist on Quality.

\section{ALFALFA}

60 Pounds a Bushel. Sow 20 Pounds Per Acre STAR BRAND

It is an advantage if a crop yields year after year without the labor and expense of re-seeding. Alfalfa is a long-lived perennial, and after becoming rooted will stand for two decades. It belongs to the leguminous family, as do clovers, cowpeas, soybeans and vetches, drawing its substance of nitrogen from the atmosphere and enriching the fertility of the soil. Land well set in alfalfa will pasture 20 Land well set in alfalfa will pasture 20
head of 125 -pound hogs per acre. The length of the season during which pas-

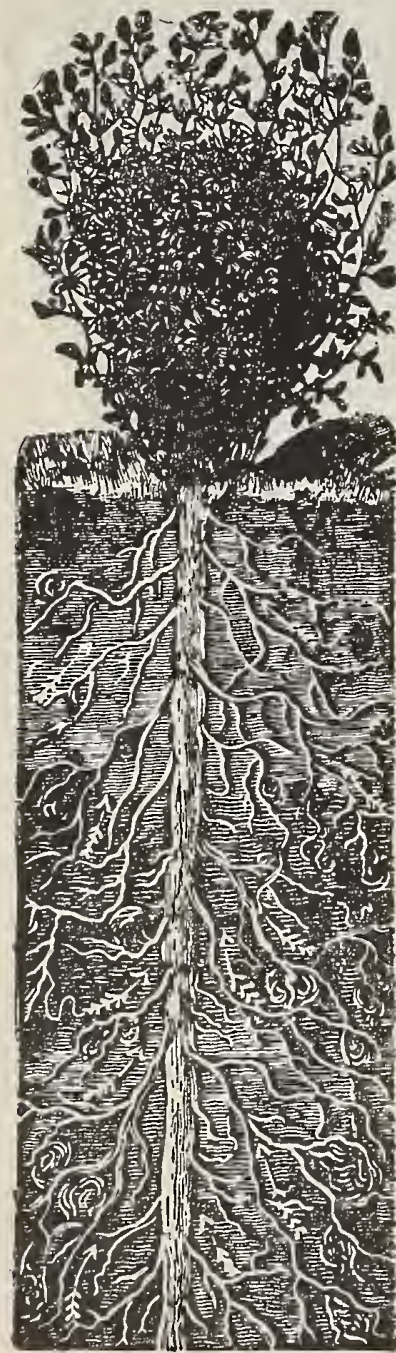
turage is furnished varies owing to localities, but extends from April to November in this latitude. One cause of failure with alfalfa is heavy pasturing regardless of whether the ground is muddy or the season dry and hot. Ordinarily alfalfa should not be pastured until the second year if it is desired to keep the field as permanent pasture. It requires a full year to get it well based on $\$ 5.20$ per each hog pastured with hogs selling at 5 cents per pound, making an income of $\$ 75$ to $\$ 100$ per acre from alfalfa fields. The above estimate is from Bulletin 84, experiment on basis of 35-cent corn, showing the relative difference in feeding corn and alfalfa and showing a gain of $\$ 5.20$ per head in favor of alfalfa. Special prices and information on application

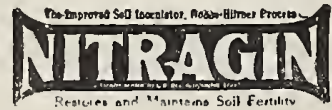

\section{MEDIUM RED CLOVER} STAR BRAND

60 Pounds a Bushel. Sow 8 Pounds Per Acre

(Trifolium Pratense.) There is hardly a farm in this section that does not have at least a few acres of clover. Its value is so well understood that it is unnecessary to call your attention to its good points. We have several thousand bushels of American-grown seed that has been thoroughly cleaned and run over our New Plantain Cleaning Machine and has been given a careful growing and mechanical test and can be absolutely depended upon. Many crops of country seed we have taken in have cleaned out 30 per cent, 40 per cent and even 50 per cent. Therefore, re-cleand seed gives much better results. Clover direct from the huller contains a large quantity of chaff and weed seeds and is always expensive. Bear in mind that it takes less seed when you sow the best. Price on application.

\section{CRIMSON CLOVER} STAR BRAND

50 Pounds a Bushel

\section{Sow 20 Pounds Per Acre}

Farmers should take every available means of sowing all their vacant land in Crimson Clover, as it makes a fine winter clover crop-an excellent grazing crop during the winter and early spring the earliest green feed-a good early forage crop, and a splendid soil improving crop to plow under early, to be followed by corn, cotton or other crops the same year. A crop of Crimson Clover plowed under is equal to an application of stable manure. It makes land rich and mellow, fills it with humus or vegetable matter, and increases the field of corn, follow it, to a wonderful extent. Write

\section{GRIMM ALFALFA} STAR BRAND

60 Pounds a Bushel. Sow 20 Pounds Per Acre Resisting, Heavy
Hardiest of All. and ordinary Alfalfa is in the root growth, the Grimm having a spreading or branching root with many laterals, while the ordinary root growth gives the plant a firmer hold on the soil and prevents the plants from being heaved out of the ground by frequent freezes subsoil. On deep soils or where the tap root can penetrate the subsoil in search of water the Grimm has no special advantage over the ordinary Alfalfa. Write for prices.

\section{Mammoth or Sapling} STAR BRAND

60 lbs. a Bu. Sow 8 lbs. per Acre

Similar to Red Clover, both in the appearance of the seed and habit of growth; the difference being that it usually grows larger and is later in maturing. It is considered superior as an improver on account of the extra growth. The appearance of the seed is identical with the Red Clover, and on this account it is impossible to distinguish any difference between them. We always obtain our supplies from reliable sources, but in this, as in all other seeds, we give no warranty but use every reasonable care to supply Mammoth or Sapling Clover as ordered. 


\section{WHITE CLOVER}

60 Pounds a Bushel, Sow 5 to 6 Pounds Per Acre STAR BRAND

This is very largely used in lawn and pasture mixtures, and is indigenous to the soils throughout this section. It makes a small, close, compact growth, covering the ground like a carpet. Sow either in the spring or fall. It is better, however, sown in mixture with other grasses. See our Special Mixture, 60 pounds to bushei. Write for prices.

\section{ALSIKE or SWEEDISH CLOVER}

60 Pounds a Bushel. Sow 6 to 8 Pounds Per Acre STAR BRAND

(Trifolium Hybridum). Alsike clover is especially valuabie for growing on wet or swampy land. If you have a piece of land that is too damp for Alfalfa or other clovers or grass sow a mixture of about 4 pounds of Alsike Clover and 10 pounds

Alsike Clover is very hardy, is perpetual, will withstand drouth and will not winter kill. About 6 pounds will sow an acre and, a the seed is very fine, it should be covered very lightly. For bottom lands needing drainage but not subject to overflow an excellent mix Clover and 10 pounds of Timothy per acre. Write for prices.

\section{JAPAN CLOVER or LESPEDEZA}

25 Pounds a Bushel, Sow 15 to 20 Pounds Per Acre

Is grown and used more in the South than in the North. In some sections it makes a fine hay crop but usually grows about 6 to 8 inches high. Makes fine pasture and grows on most any kind of soil. Where the stand is thin the plant has a prostrate habit, but when thick, grows upright. Yields often make 2 tons per acre, and have been known to go 3 or 4 tons. It grows on all types of soil and Purnishes forage on barren gravelly wastes where no other crop will grow. It stands any amount of grazing, and cattle will fatten on
pasture. It is especially valuable grown in combination with Red rop or Bermuda Grass. Write for prices.

\section{BURR CLOVER}

Sow. 30 Pounds Per Acre Unhulled. 8 Pounds Per Acre Hulled 60 Pounds a Bushel Hulled. 28 Pounds a Bushel Unhulled STAR BRAND

Adapted for summer and fall seeding only. For the South it is a most valuable winter grazing crop, growing luxuriantly all through the winter and until summer. After once being seeded, it re-seed and improves in growth each succeeding year. It is admirably adapted for growing with Bermuda Grass, the combination makes a splendid all-the-year-round pasturage. Write for prices.

SAN-FOIN or ESPARSETTE CLOVER STAR BRAND. Sow 15 Pounds to Acre

A perennial leguminous plant belonging to the Clover family. It is especially valuable for growing on poor land and hillsides, but produces on good land an abundance of nutritious food which is eaten with relish by all stock. It is especially adapted for sheep pasture and is considered nearly free from bloat for cattle. To be put up for hay it should be cut just before the flowering period. Write for prices.

\section{HUBAM CLOVER STAR BRAND}

60 Pounds a Bushel. Sow 10 Pounds Per Acre Broadcast

Discovered by the Ames, Iowa, Experimental Station in 1916 and raced to Alabama as its place of origin, this ivonderful clover has placed itself in the Agricultural Hall of Fame for all time to come superior to other Clovers for hay and pasture purposes. Exceedingly fine for milch cows, is a great fat builder, and is one of the greatest soil builders of the Clover Class. Our Certified seed is the Best that can be secured anywhere. Price per lb., 6.5e; 5 lbs., \$3.00; 10 lbs. $\$ \$ .50$. Postpaid.

\section{SWEET CLOVER} STAR BRAND

60 Pounds a Bushel. Sow 8 to 10 Pounds Per Acre WHITE BIEN NIAL- (Melilotus Alba, or Bokhara.) The white-flowered variety frequently seen growing wild along the roadsides. Many farmers are using this as a pasture Clover, claiming it to b equar to common Red Clover for this purpose. In growing it for hay, it is cut when about 18 inches to 2 is set about 6 inches above the ground it will cut above the first branches and the Clover produces a second crop. If cut too close to the ground, the plants are not likely to survive the first cutting. Germinates more quickly and freely if sown on a well-prepared seed bed. Price on application.

ELLO W HENNAL-(Melilotus Officianalis.) Is svery similar to the commoner white-flowered (Melilotus Alba), but blooms a little son is claimed to be superior. Price on application.

YELLOW ANNUAL-(Melilotus Indica.) A small annual variety used for quick pasture, as it grows quite rapidly and is ready for grazing in 60 days. for inoculating the soil for alfalfa and for bee pasturage. Sow 10 lbs. per acre.

\section{ORCHARD GRASS} STAR BRAND

14 Pounds a Bushel. Sow 20 Pounds Per Acre

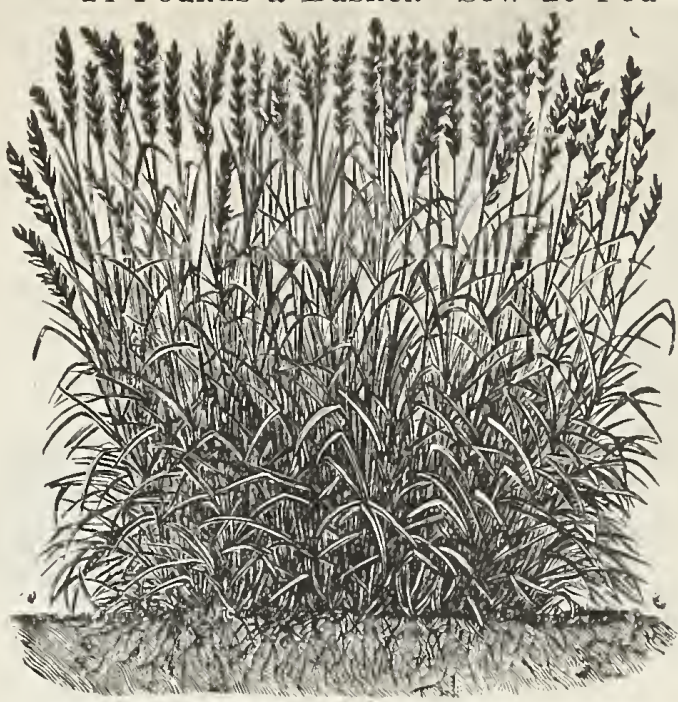

The King of Pasture Grass - More Profit Than Wheat.

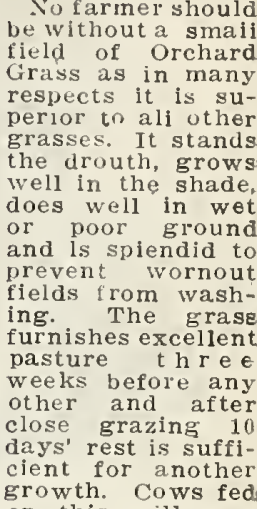

a d makes a very dapted and when set remains for many years. It is especialiy

bushel. Prices on application.

\section{KENTUCKY BLUE GRASS STAR BRAND}

14 Pounds a Bushel. Sow 14 Pounds Per Acre

Blue Grass is still being listed as Kentucky which is correct to Trass state and in a lew years more Blue Grass will be listed as USE SHEEP GUANO TO FERMLIIS: GIN TILIZE, See Inside Back Cover

SPFLTZ OH EMMER-40 lbs. a bu. Sow 28 lbs., to acre. A grain the grain drouth-resisting wheat, and not inclined to rust. Thrives on poor and in stony ground. The experiment stations of both the Dakotas report that it resists drouth better than oats or barley. All arly. Write for prices.

LAX For sowrva-56 los. a bushel. Sow $28 \mathrm{lbs}$. to acre. The demand for this seems to increase each season. It should be sown
late enough in the spring to avoid frost, but early as it is possible to do so in order to secure the early rains. When grown for the fibre about 1 bushel should be sown to the acre, but for seed alone for prices

HUNGAHAN BRONE, OR AWNLESS BROME-14 lbs, a bushel. Sow providing splendid pasture or . It makes quick, strong growth growth very quich deal gras

\section{TIMOTHY and ALSIKE STAR BRAND}

50 Pounds a Bushel. Sow 8 Pounds Per Acre Timothy and Alsike are well adapted to grow together as both damp soil; both are perennials which enables

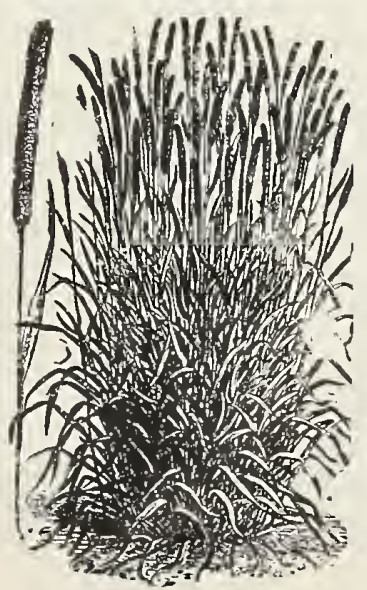

TIMOTHY

STAR BRAND

45 Pounds a Bushel Sow $71 / 2$ Pounds Per Acre Very little seed is harvested in this imm sutely cinity. Therefore, most of north of ys secured into the Timothy sections and purchase direct from first hands. The seed is rough, re-cleaned and offered direct to the farmers at a minimum handling expense. We are the only house in this Cleaning Seed Machines Ours are of the very latest patterns. We have every conceivable convenience for handling seeds at the lowest possible cost, and are. therefore, in position to offer you values us your requirements and ask us for prices. 


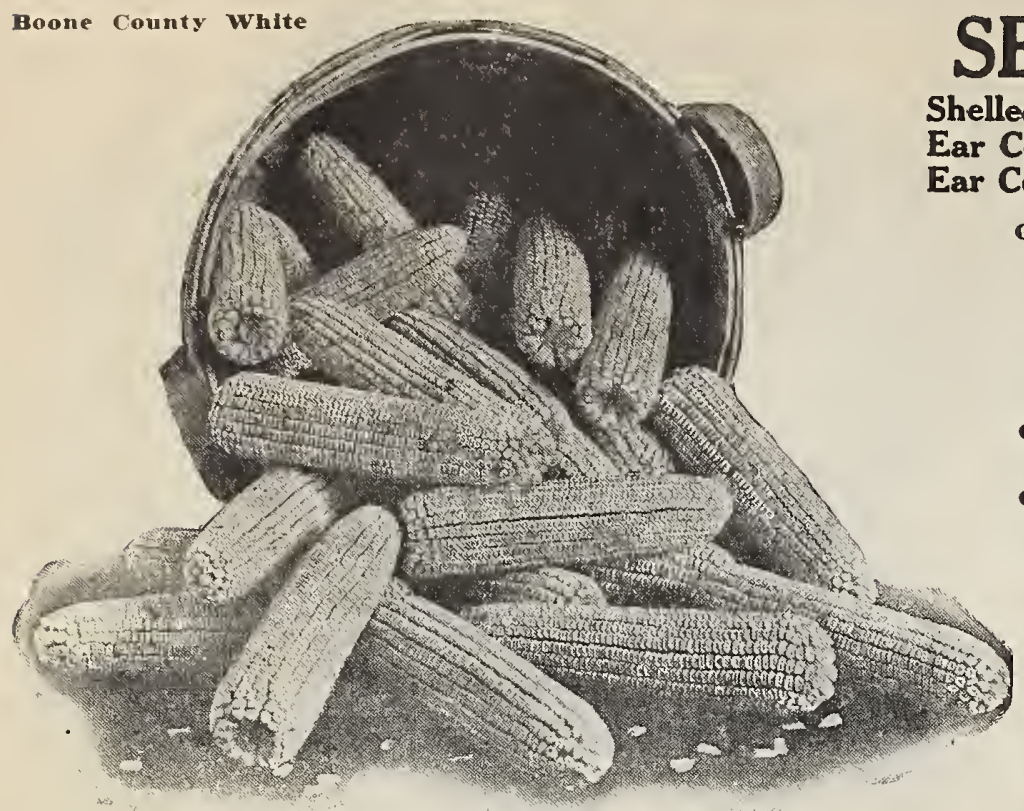

BOONE COUNTY WHITE-(THE OLD RELIABLE WHITE CORN.) By long and careful breeding has proven itself to be the highest ylelding white Corn known. In general appearance this Corn is a pure white, large ears and deep medium rough kernels. Length
about 8 to 11 inches, averaging 12 to 18 ounces. The cob is medium large and pure white in color. Ears cylindrical-producing a maximum amount of shelled Corn. Boone County white is par-
ticularly adapted for milling purposes. making a fine white meal,
and often there is a premium offered for this white Corn over the and often there is a premium offered for this white Corn over the
yellow by the millers. The rooting system of this variety is exyellow by the millers. The rooting system of this variety is ex-
tensive and it withstands the dry weather and winds remarkably well. We recommend Boone County White especially. Write for prices.

ST. CHARLES WHITE-The famous Ensilage Corn of the South. We have improved this type and have perfect success with it in this climate. Matures in 110 to 115 days. Pure white Corn, red cob. medium small; grain extra deep, clear, transparent white that makes it much sought after my millers, who give a premium for it. Long cylindrical ears, 9 to 12 inches long; 8 to 9 inches in circumference. Medium large shank; medium rough dent. While this is crop, you get as large a yield of actual Corn as any other variety and the feed value of the grain is unexcelled. The deep grain and large ears make it yield as much shelled Corn to the acre as any variety that is grown for grain yield only. If you are looking for
profit in Corn raising, order some. Write for prices.

IOWA SILVER MINE-Ninety-Day Corn. Stalks grow to a height of 7 to 8 feet and set the ears about $3 \frac{12}{2}$ feet from the ground. It has not a large growth of fodder, having been bred essentially for well rooted as any Corn grown. The ears measure from 10 to 12 inches in length and weigh over $11 / 2$ pounds. They are uniform in size and shape, with 16 to 20 rows of deep, pure white kernels. on small white cob. It is ready for market earlier than any white Corn grown. Seventy pounds of this Corn in the ear will make PRIZE MEDAL SILAGE CORN-One of the very best Silo Corns grown. Big tall juicy stalks. broad thick leaves, which remain green long after other varieties are fired up. Big, white, milky kernels. Ears 11 to 16 inches long; 18 to 24 rows on the ear. One
piece grown last year stalks averaged 16 feet tall. Write for prices. EUREKA SILAGE CORN-One of the standard silo Corns-good big stalk and ear. Considered by some feeders as the best for the silo. Write for prices.
HICKORY KING-This is an entirely distinct variety among the White Corn, combining the largest grain with the smallest cob. A single grain will completely cover the cob of an ear broken in half. It is a great yielder, giving more shelled Corn to the acre of soil, and will produce good strong stalks, bearing two, and occasionally three good ears. A good drouth resister. We recommend row GoID MiNe-This grand variety is an improved strain of Pride of the North. It is early ripening, being much larger but a golden yeliow color. It has been a favorite among stock feeders, from the fact that the cob is small, grain soft and very deep. Seventy pounds of ear Corn will make sixty pounds of shelled IMPROVED IEAMING-Ninety-Day Corn. Improved Leaming is medium early. The ears are large with very deep bright yellow
kernels. The cob is small. The stalks grow to a medium height and often produce two large ears and make first-class fodder. This of high-grade deen yellow Corn. One of the best varieties to sow for fodder and ensilage as well as for grain. Prices on application.
JoHNSON COCNTY WHITH DENT-The shape of the ear is cylindricall to within about 2 inches of the tip, then slightly tapering. Tins
fill well over the end and a large per cent of the ears are entirely covered with grains; the butts are well rounded out with a me-
dium sized shank; kernels very uniform, wedge shaped. pure white cob; ears average about 10 inches in length with the circumference about $3 / 1$ of the length. Of strong and vigorous habit of growth
and well covered with broad blades-very valuable for ensilage Length of season, about 120 days. Write for prices.
SEED CORN

helled Corn 56 Pounds a Bushel Corn Shuck On 70 Pounds

Corn Shuck Off 65 Pounds
Nubbed, Tipped, Butted. Graded and Tested for Germination. There is positively no comparison of our Seed Corn and the average Corn.

GATE POST-This is now one of the most prominent late varieties of Yellow Dent Corn in the country. It is the result of years sepremilums a seed Corn specialist in Iowa, and has taken first and of uniform pure yellow color, ear very large and long and a deep grain on a small cob, while the stalk does not grow too large. It is capped over and the kernels hold their bigness toward the point, the butts run out straight and not crinkled. It matures in point, the butts run out straight and not crinkled. It matures in CHAPMANS PIONEER-White Hybrid 110 Days. Long, smooth, large ears. Medium grain and one of the best feeding corn grown. Is

CHAPMANS PROSPERITY - Yellow, 100 Days. Long ears, deep grain. Red $\mathrm{Cob}$, good yielder and fine for feeding. Made this year 60 bushels to the acre, has been grown for 20 years by Mr. Chapman. who claims it the best yellow corn grown.

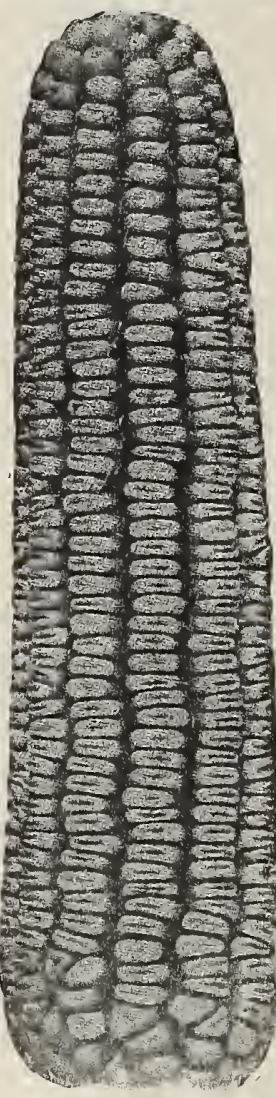

Gate Post

IMPROVED GO L D EN BEAUTY-The

are of perfect shape with from 10 to 14 yellow grain, remarkable in size and filled out completely to the extreme end of the color and fine quality
of grain make it vastly superior for grinding into meal. The grains flinty nature, neither are they so soft as to be greatly shriveled. The ears are easily kernels are firm on the ear and in every respect as perfect a type as could possibly matures in 100 days from planting and surpasses all in size and
beauty of grain. Prices on application. A good, reliable etv, extra large ear. grain red and white drouth excellently.
REID'S YELLOW DENT-Thoroughbred, pedigreed, carefully selected stock. During the past 5 or 6 years this variety has come rapidly to the front and now occupies a prominent position in all lists. It is of handsome shape and color and largely grown for exhibiting. at fairs, Corn shows and is used by many Corn schools as a standard for judging, and is too well known to require lengthy description. We have selected the choicest ears so that we are sure our seed cannot fail to please the most particular. It is of handsome yellow color, smooth, deep grained and the kernels are packed very closely on the cob, ity. Matures in about 115 days. Write for prices.

SWEET CORN FOR FODDER-There is nothing better for green food or for curing for winter than Sweet Corn. Cattle highly relish it, and when fed on it keep in rine condition and give an abundeing so sweet and palatable that cattle eat every part of the stalks and leaves and consequently none is wasted. Farmers in this section should raise more Sweet Corn as feed for young hogs, which is sure to give better results than feeding common field Corn. Sow thickly in drills or broadcast, at the rate of 2 or 3 bushels per acre. Write for BLOODY BUTCHER-One of the largest Corns grown. Very late. Grain red and yrite for prices.
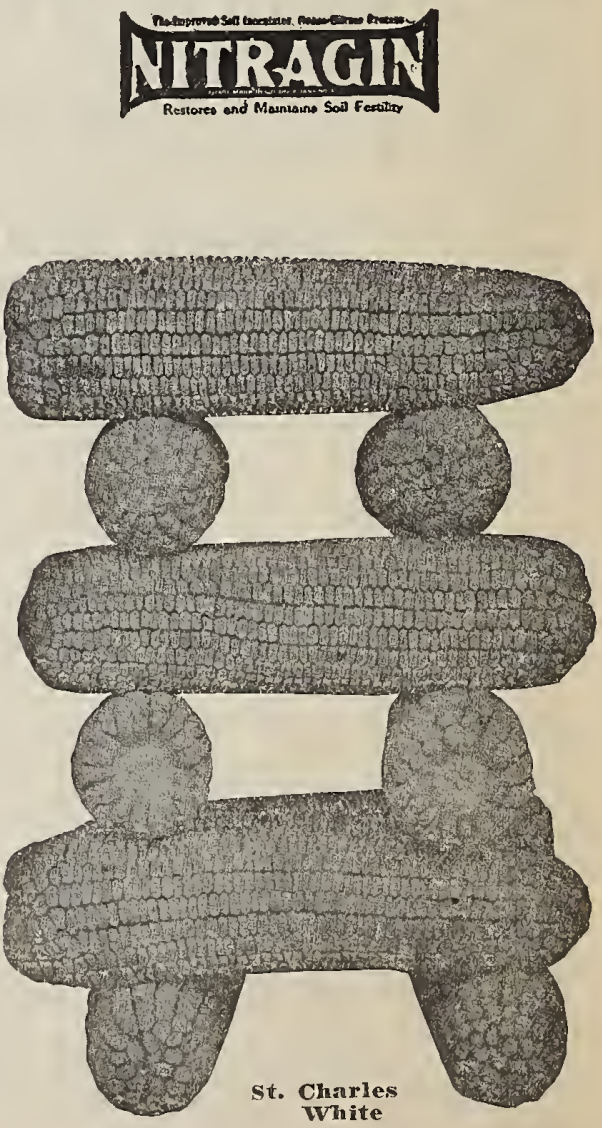
BRAzILIAN FLOUR CoIrN-One of the grandest plants ever introduced. It withstands drouth, makes better roasting ears than does any of the Sugar Corns. By planting every month it will furnish green Corn all the season. Comes in early and remains late. May be planted on stubble after grain cropo der such treatment, make a big crop or both grain and fodder. The grain makes most excellent four, as well as hominy. The ear The lons, and contain from at to 12 rows ly white grains. The grain may be ground at any grist mill and the flour made from lt makes as fine breakfast cakes as buckwheat. Owing to its heavy stooling habit it produces an enormous crop of fodder.

MPROVED INDLAN SQUAW CORN-Something new in the Corn line This Corn is the most profitable variety cultivated; drouth resist ing and early maturing, which makes it a case of sure money. Can be planted in June or July after wheat harvest and matures in 85 days. The grains are a variety of colors, red, yellow, blue and white, which makes this Corn a good looker on the cob or in the bin. The demand for this Corn was very heavy last year; in fact, we were unable to fill all orders. We have secured a good supply this year and will. order early and be sure of getting your share of this wonderful Corn. Lb., 25e. Postpaid.

\section{BROOM CORN}

48 lbs. a Bushel, 36 lbs. Per Acre.

\section{BARLEY STAR BRAND}

48 Pounds to a Bushel. Sow 95 to 100 Pounds to Acre WIIIC IIULUESS HITE HULLESS BARLEY-One of the most prolific of the Barley ramily, giant growing and heavy yielder, makes this Barley on you can't pass up. As a hog feed lay you can fced nothing better. Write for prices.

BEAIRDLESS SIRING IBALEY-This crop has been sown with ver satisfactory results for several seasons past in this section and further south. It makes a quick growing crop of most excellent and nutritious green feed and is growing in popularity wherever it is used, and will also make a good grain crop, ather to feed preen or to cure as hay. T'o cure for hay, it should be cut while the grain is in a milk state. Price on application.

IBEARDED RAIRLEY-Very popular variety; large quantities planted every spring. Price on application

ARLEY - This is also a new plant, one which as not received the attention it fully merits. This is one of our very best winter grain crops. be grown for pasture or grain-in fact, it may be used in either of the five ways recommended for fact, it may be used in either of the time we sow winter wheat, or for price on application.

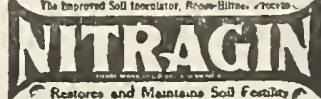
Use Sheep Guano for Fertilizer see Inside of Back Cover

\section{BUCKWHEAT}

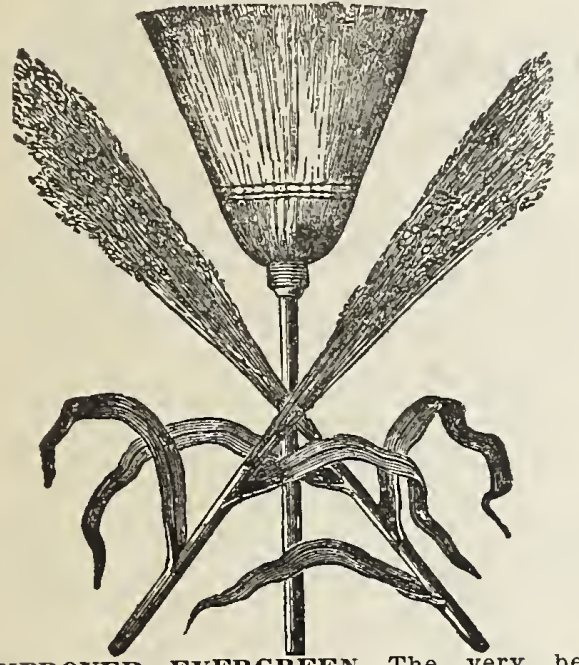

IMPROVED EVERGREEN-The very best variety for general cultivation. Grows 8 fine grade, and has a nice green color after being cut. Our stock is strictly selected stock and from professional growers. Price

DVARF EvERGRERN-Very dwarf in fowth, 5 to 7 feet sweep; is very fine cultivate and handle. Price on application. WHITE ITALIAN-Medium size quick growing, long sweep of fine texture, is proving it this year.

BLACK SPANISH-Medium tall, long sweep. Heads have 5 to 15 more straws than other sorts. Sweep is dark green and work Write for prices.

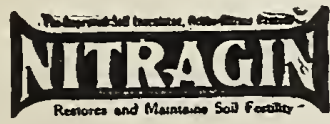

\section{RAPE}

\section{DWARF ESSEX}

Sow 8 Pounds per Acre

Under ordinary circumstances. Rape is ready for pasture in six weeks from time of sowing. One acre of Rape will support a dozen sheep for two months. It has been shown that an acre of Rape will produce as much gain on hogs when pastured along with grain, as 56 bushels of corn will do. In fact, they will gain more rapidly than when fed on grain alone. A plant with a great feeding value, should be found on every farm where sheep and hogs are raised. An acre of Rape will produce more than an average acre of corn and the cost of production is much less, as the hogs gather the crop of Rape themselves.

CULTURE-Prepare the ground as for turnips and sow in June or July, with a turnip drill, in rows $21 / 2$ feet apa and very productive, yielding as high as 40 bushels to $1 / 2$ bushel of seed. The kernels are RYE

\section{STAR BRAND}

56 Pounds a Bushel ance of growth, and in yield of grain. It was and in the United States 3 or 4 years so much superior that the seed was in big deheen a hood where it was first introduced, and has also grown on other sections on the Atlantic It is fully a week or 10 days earlier in maturit than the ordinary Rye, and some farmers claim makes a quick and vigorous growth, and mature grain decidedly in advance of the regula decidedly increased yields of grain. We recommend to our customers to grow this variety exmand at increased prices for a number of years PRING RXw-Sow in the spring about the time you sow oats. The average yield is about 30 to 40 bushels to the acre. In case your winter sowRye. Sow 1 to $11 / 2$ bushels to the acre. $\pi 1 / 4$ to $11 / 2$ bushels to the acre.
WHTE RYE-Sown both in the fall and spring does best sown in the fall. Sow $11 / 4$ to $11 / 2$ OOSEN RYE-A new Rye from Russia. Grown in The United States about 3 or 4 years and has proven the most wonderful of any Rye grown. Grains about twice as large as the common Rye and has made an averge of about 40 to 45 havels per acre. Far

(Vicia Villosa.) Als

\section{VETCH-Sand Winter}

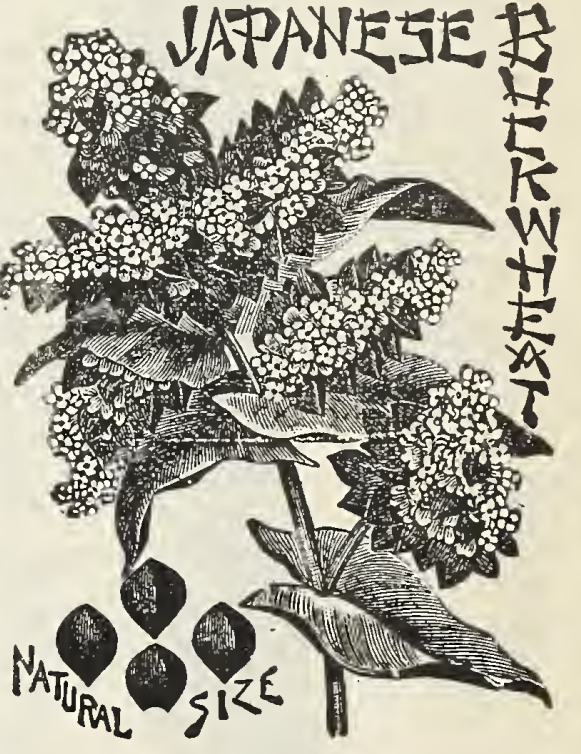

SUNFLOWER SEED-Mammoth Russian Manchurian. Grow Sunflower Seed for the market. Make 1 profit. We can use large lots. Write. 作 true value. It is noted for its extreme hardiness, is highly valuable in the North ls noter forage and fertilizing purposes. It withstands hard winters, being hardier than wheat. It does well on nearly all soils and is especially recommended for poor land, where it thrives and improves the soil ter and is valuable for early pasturing as well as for fertilizing. It is extremely early and has enormous value for feeding purposes. brouth, heat and cold do not affect
kinds of stock. Write for prices.

\section{SPRING VETCH}

Spring. (Vicia Sativa) Much like the preceding in growth and habit, and une seed of Spring Vetches is mu is resistant to cold weather, but if sown early in the spring, either by themselves or in connection with grains, grasses or clovers, will produce a vetch apply to this sort aiso. 


\section{PEANUTS}

This crop is naturally adapted to a light, sandy land. When properly cared for, it will yield a good profit as a market crop or as pasturage for hogs. Shell the seed before planting, and plant in rows 8 feet apart, hills 10 inches apart. Peanuts should be planted in May or June.

gPANISH-For home use we think this variety by far the superior of any that we know. The kernels are sweet, with a rich flavor. This is a very prolific variety. Lb., 25e. Postpald.

TFLCT VIRGINIA-A large, heavy yielding variety. This variety is more widely grown in the South than any other. It is the standard commercial variety and commands top prices. The nuts are large and well shaped, containing 2 and of ten 3 kernels. Lb., 25c. Pontpald.

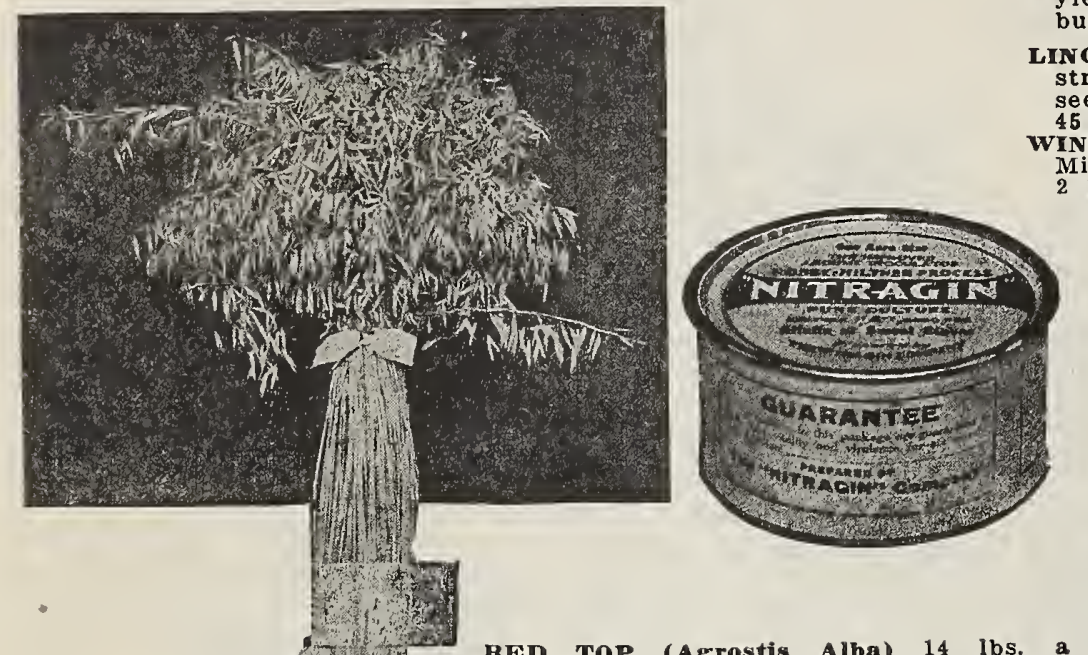

RED TOP (Agrostis Alba) 14 lbs. a bu. Sow 7 lbs, per acre.-A grass parground that washes. It is often sown with Alsike clover, which together makes a good hay. Is quicker to start than any other grass and on moist soll will grow about 2 feet high, and on gravelly or poor soil 1 foot high, if used for pasture should be fed close, as after It has gone to seed cattle will refuse it. It is also used for terraces and patches in lawns, where blue grass will not grow. Per 1b., 45e; 10 lbs., \$4.00.

sown of our 48 pound per bu. seed last geason.

\section{TEOSINTE}

A single seed producing from thirty to sixty stalks, each 10 to 12 feet high, gives some idea of what an enormous yinte may be had from Teriment station reported a crop of more than 50 tons on an of more than 50 tons on an acre. If cut when 4 or 5 feet high, it makes an excellent rowth again, and will give growth again, and will give as the first; we have known as the first; we have known son. If sufficient is planted a continuous supply of nutritious green feed can be had daily right up to frost. The eaves are longer and broade cent of sugar, and are cent of sugar, and a kinds of stock. ly eaten by all kinds of stock. It makes splendid ensilage, but is more particularly cutting green feeding crop. Plant in May or June in drills $31 / 3$ to 4 feet apart; 2 to 3 ibs. plant an acre.
OHNSON GRAss (Sorghum Halapense) 25 lbs. a bu., sow 20 lbs. per acre. Johnson grass is only sown in the Southern states, Southern Kansas being about as far north as it can be successfully grown, as it is very easily winter killed. Is a rapid grower, with long canelike roots and stalks and leaf resembling sorghum.

MEADOW FESCUE, OR ESGLISH BLUE GRASS (Festuca Praltensis)-A permanent pasture grass: grows from 2 to 3 feet high and is the earliest and most nutritious of grasses; makes excellent hay, and cattle will thrive on it. It grows better in poor soil than any other grass. The roots grow from 12 to 15 inches under the ground. It can stand extremely dry weather: also will stand more freezing than any other variety. Sow 15 to 20 pounds per acre. Per $1 b$., 30e: 10 tha., $\mathbf{3 2 . 5 0}$

ITALIAN RYE GRASS (Lollum Italcum)A quick growing grass and is often used as a nurse crop for Kentucky Blue Grass and in lawn mixtures. Wiil make a quick showing and is used where something green is wanted in a hurry; it is of no use for permanent pastures, as it lasts only two years. Sow 35 to 40 pounds per acre. Per lb., 30c; 10 lbs., \$2.50.

\section{SEED OATS \\ STAR BRAND \\ 32 Pounds to a Bushel}

We take great care in the selection of our seed Oats, and whon say Seed Oats we do not mean field run or just common Feed ats but strictly high-grade fully matured, graded and cleaned oat hat run 32 to 36 pounds per bushel. There is offered every sprins ats for seed at 5c to 15c less per bushel than our Oats, but the 作 25 to per cent difference in the quality and crop. Don't be misled by oft soap and cheap prices. See the Certificate of Anaiysis on every for prices.

XAg RUST PROOF-This variety needs no long description; our tock is strictly Southern grown seed which is the best to be had. 2 bushels per acre.

URLY WALLACE-The old standard early yellow oat; makes good ield and matures before the hot weather sets in. Sow $1 \%$ to 2 ghels per acre.

WHITE-This is positively the best white Oatg grown trictly northern stock, clipped and screened, which is the heaviest eed Oats per measured bushel on the market. It usually makes 5 to 75 bushels per acre in this section.

NGR TURF-Valuable for winter pasture in the southern part of issouri and southern states. Sow in August and September, $1 / 2$ to bushels per acre.

\section{SUDAN GRASS}

\section{STAR BRAND}

SUDAN-The wonderful crops produced from Sudan Grass has put in a class by itseif as a feeding Grass. It is more nuritious than cane or kaffir and stock eats it to the last fraw. There were more acres put into sudan Grass the past four years. As a possible 75 per cent was cut for hay last ast season. Prices on application.

GROWING THE CROP-It may be grown either drilled, in cuitivated row or broadcasted, if planted in cultivated rows, the rows should be as close as possible, and yet permit of easy cuitivation. In 30 -inch rows, 2 to 3 lbs. of seed per acre is ample; and under conditions of very low rainfall, this metho is recommended. Under humid conditions 18-inch rows are preferable, and, 5 lbs. of seed per acre are sufficient. For drilling or broadcasting, 15 to 25 lbs. of seed per acre, depending on rainfall, should be used. The seed should not be sown corn. The young plants will withstand slight frost without injury.

YELLOW MILO MAIZE-This makes a thick, succulent growth of forage, very nutritious, and of spiendid milk producing qualities. This, like sorghums, can be cut over 2 or 3 times, where it is desired so makes where it is desired to cut for green forage. Also makes prices.

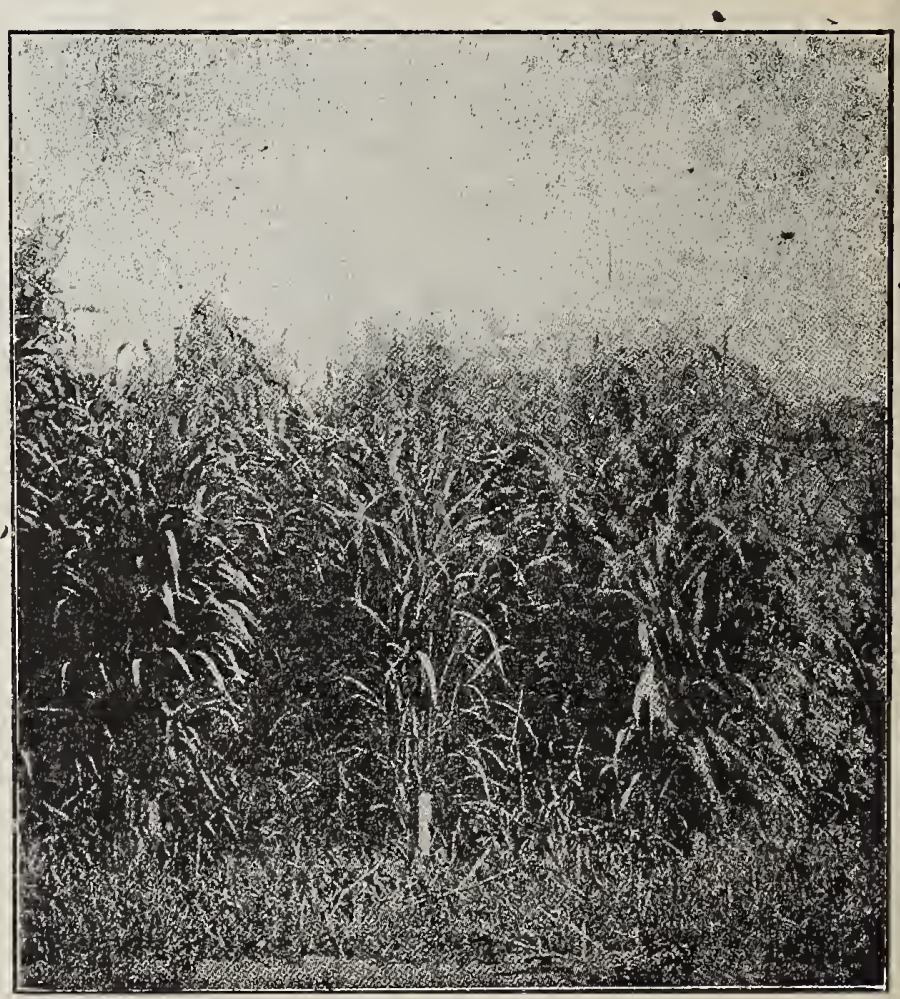

GUDAN GRAss 


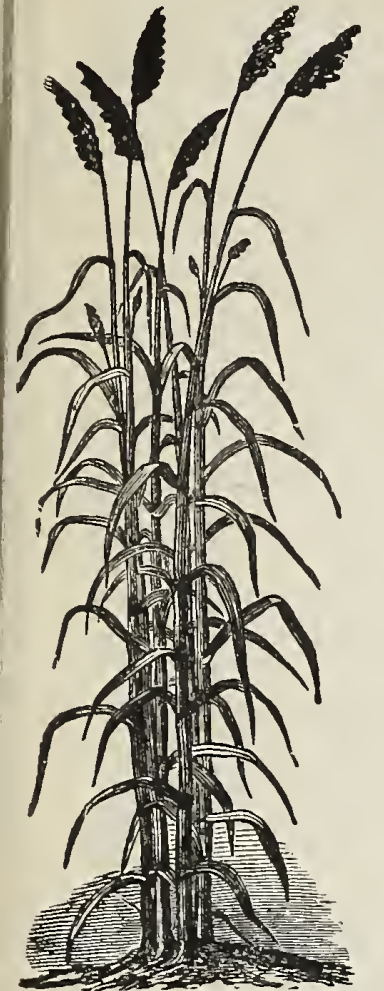

Late Orange Cane

\section{CANE SEED}

\section{STAR BRAND}

50 Pounds a Bushel.

Sow 100 Pounds Per Acre for Fodder

BLACK AMBER CANE-Ail kinds of stock are exceedingly fond of it, and the armers all over the country are beginning to realize that it is one of the best green fodder plants that can be produced. Its earliness adapts it to almost every section of the country, and its enormous yield often reaches 20 to 25 bushels of seed, and country, and its enormous y laren or exceedingly difficult to procure pure seed, but the stock we offer is the best that can be obtalned.

EARLY ORANGE CANE-Very much the same as the Black except the seed is red hulled. Write for prices.

RED Top-(Sumac or for prices, is a stout stocky variety with an abund ance of large, broad leaves. The seed heads are stout thick cylindrical and erect, 6 to 9 inches long, blunt and somewhat spreading. The seed is the smallest of any of the varieties grown, of brownish-red color. It is medium early variety, very sweet and largely used for both hay and syrup. Grows from 7 to 10 feet high, requiring from 90 to 120 days to mature. somewhat later than A growing variety; considered good for sorghum, somewhat later than Amber.

TEXAS SECDED RIBBON CANE-(Sometimes called Gooseneck.) The superiority of this Cane over Sorghum is so great that when once grown man never returns to ther Sorghum is so great that when once grown a made from it is much knows who has used Ribbon Cane syrup. Another good feature of this Cane is the great yield it makes. The stalks grow from 12 to 14 feet high. Cut with the foliage on and run through the mill. it makes the finest kind of silage for cattle and horses. It matures 2 months earlier than any other Ribbon Cane, being ready to grind the latter part of August, while other Ribbon Cane does not mature before October. It will grow anywhere Sorghum will grow. In planting, prepare ground, plant and cultivate as for plant 1 acre, if planted by hand; 8 to 10 pounds it planter is used. Write for prices.

JAPANESE HONEY DRIP-Used most exclusively for Sorghum. Makes extra fine grade of syrup. Write for prices.

KAFFIR CORN (WHITE)-Largely grown in the South and now coming into favor with Northern farmers. It grows 5 or 6 feet high, with a straight upright growth and numerous broad leaves. It makes the best kind of fodder for cattle or horses, and is easily grown. The seed is splendid for poultry. Sow in rows $21 / 2$ to $31 / 2$ feet apart and cultivate the same as Corn, but seed an acre if sown in rows, or $1 / 2$ bushel broadcast.

\section{FETERITA STAR BRAND}

50 Pounds a Bushel.

Sow 25 Pounds Per Acre

Similar to Milo, Maize and Kaffir Corn, in general habit. It matures earller than elther. however, and the grains are somewhat larger and softer. It is also said to be more prolific, yielding thirty to fifty bushels of grain per acre, and suitable for feeding most any kind of live stock. It is especially recommended in the semi-arid regions of the West, or upon poor soll where ordinary Indian Corn will not produce a profitable crop. Is very prolific and hardy, does

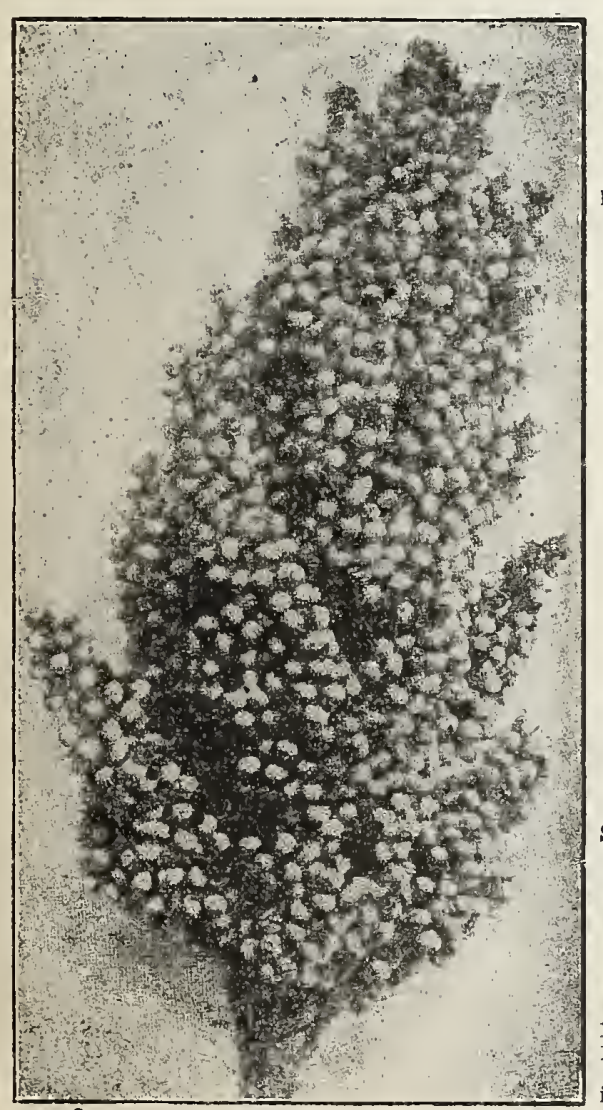

VELVET BEANS-A climbing nitrogenous plant making a rapid growth and dense mas ing under for a soil bullder Plant in April $1 / 2$ bushel to the acre. Lb., postpaid, $25 c ; 50$
lbs., by express, 10c per Ib., not prepaid.

GYPTIAN WHEAT, OR SHALLU-A valuable new grain entirely different from wheat. Belonging to the Sorghum family, it should be planted and treated as same, elther for grain or for hay.

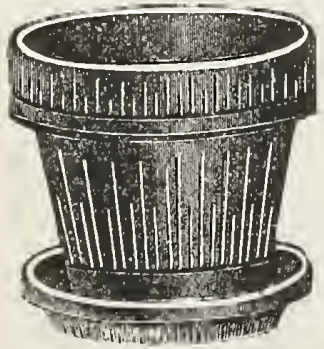

Flower Pots

\section{Measure across top of pot.}

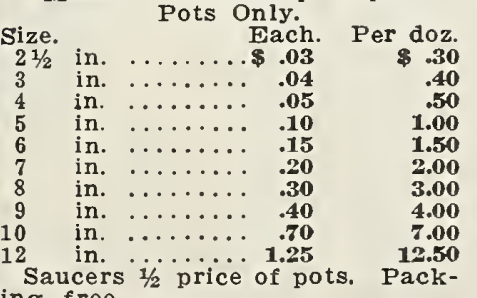
Saucers $1 / 2$ price of pots. Pack-

\section{For Best Results USE

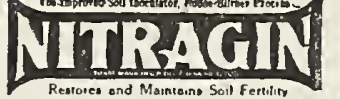

\section{MILLET \\ STAR BRAND}

50 Pounds a Bushel

Sow 25 Pounds Per Acre

GOLDEN MILLET-Formerly called German Millet. (Southern.) Tennessee cultivated. Mammoth head. The Southern the n Millet is true Golden and much superior to western or results. This is the Millet that has enormous big heads and wide leaves. It is the rankest of all Millets and makes lots of feed either as hay or grain. Can be sown as late as July in thls latitude, and on that account is valuable where other crops have been washed out and lost. Write for prices.

wHITE WONDER-No other grass or forage plant has been able to produce the enormous yield of this plant. It has become the most popular and generally used for all purposes; produces from 4 to 5 tons of hay to the acre, and from 60 to in fine condition for wheat. Sow 25 to 30 pounds to the acre. Price on application.

SIBERIAN OR RUSSIAN-Is earlier than Golden, extremely hardy and will stand more hot, dry weather than any other variety of Miliet. It makes a very rank growth, with an abundance of leaves, which start from the ground. Sow in April, May or June at the rate of $1 / 2$ bushel per acre. Write HUNGARIAN MILLET-Can be sown somewhat later than other varieties, and is well adapted to dry seasons. Makes an excellent hay. Sow 25 pounds to the acre. Prices on application.

HOG MLLET, OR MANITOBA-Has proved itself to be one of the most valuable Millets grown for hog pasturage. Seed about double size of Golden Millet. It is very rich, and especially as a hog food. It ripens about two weeks earlier. on application.

JAPANESE MILLET OR BILLION DOLLAR GRASS-Entirely distinct from any other Millet; grows 6 to 8 feet high, stands well notwithstanding its great height, and yields from 10 to 12 tons green fodder per acre. When cured it makes an excellent quality of hay, and is also much relished as green fodder. Sow 10 to 12 pounds per acre. Write for prices. PEA RL MILLET, OR PENCILLARIA-Immensely productive. 25 tons per acre. It is an annual plant having long, broad folifrom $10 \mathrm{t}$ o 12 feet, and bear numerous heads from 19 to 20 inches in length and 1 inch in diameter, completely covered with thousands of seeds, much relished by poultry. Write
for prices. 


\section{SOY BEANS}

60 Pounds a Bushel.

Plant 1 Bushel Per Acre MAMMOTH YELLOW-The Soy Bean has demonstrated a great farm value in the past few years, and could be profitably grown to a especially helpful for those who cannot grow clover. A crop of Soy Beans can be produced between spring and autumn frosts anywhere in the states. It grows on land that will make 40 bushels of corn per acre and will, if plowed under, put $\$ 16.00$ worth of fertilizer matter per acre into the soil. Land that will make $11 / 2$ tons of timothy or clover will make 3 tons of Soja Bean hay, worth more per ton than timothy. Write for prices.

MGDIU.MLLLOW-Very prolific both in growth of bush and bean. The beans and pod. are smaller than the Mammoth Yellow, otherwise are very much the same. Write for prices.

growers to 列 uses; extra good for hog pasture, and has proven excellent for milk to 3 feet high and matures in about 90 days. Try a small patch for your own satisfaction. Price on application. PEIIN-Similar to the Black, except in color, has heavy foliage and MonsE-Grows about 2 feet. Medium early and very prolific. Write for prices.

BLACKS - Very early and heavy producer. Recommended for Northern planting. Write for prices.

RGINIA-On account of its abundant growth and large yield of is about 20 days earlier than mammoth Yellow, it can be As it further north and throughout the corn belt. The vines mak grown growth, are filled with pods, stand about 3 feet high, are easy to cut and easy to cure.

WILSON EARLY BLACK-A very prolific variety, and one of the best where a quick, early variety is desired. Average height on good land is about three feet. The Delaware State Experiment son Black as ahead of any as a combination hay and seed variety. It was found to mature in about 115 days, to stand up well, make pods a good distance from the ground and retain its seed. Its fine stem enables it to cure quickly for hay.

HoLLYBRooK EARLY-Makes a quicker growth and matures its crop two or more weeks earlier than the Mammoth Yellow and makes a large yield, both of forage and pods. It is a sure cropper GRASS SEEDERS

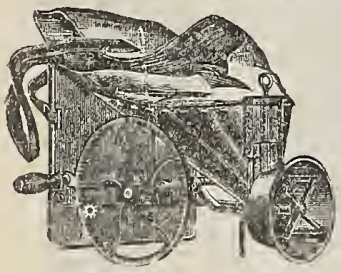

One of the best Seeders

the best

$\$ 5.00$

Perfection $\ldots \ldots \ldots \ldots \$ 2.00$

s. s. $\$ \mathrm{r} \ldots \ldots \cdots \cdots, \mathbf{1 . 0 0}$

The Cahoon

Postpaid.
COW PEAS

60 lbs. a Bu. Plant-Broadcast $60 \mathrm{lb}$.

Acre. Drill 1/4 Bu. Per Acre

Write for prices on Cow Peas, Soy Beans, Cane, Kaffir and Millet. WHIPPOORWILL-Is a medium early sort, making a rather stocky, healthy growth of vine with a large amount of seed. It is probably the best known all-purpose variety grown. Seeds are speck

NEW ERA-The earliest variety and the quickest to make heavy growth. They are bushy in form, rather than trailing, and will just about meet across a 3 -foot row. For the Corn Belt and for quick results anywhere they are the best variety to grow, making

heavy yield of seed and a fine quality of hay.
THE CLAY-This is so-called from the color of the seed, which is the color of reddish yellow clay. The plant is of the same season and habit of growth as the Black. Many growers in the South prefer it to the large Black because of the fineness of the growth, which makes it easier to cure.

BLACK-It is about a 100 -day Pea from planting to ripening of seed. Trails freely and makes a heavy crop of hay. In fact, one of the best for hay as it will get into conditio

GXTRA EARLY BLACK EYE-This Pea is one of the earliest. It is a strong grower and moderate trailer. It will mature seed in about 60 days. A very valuable hay crop can be made from it in the for table use, and takes the place of the white beans in the North. As a soup Pea it is very popular.

Ripper, Sugar Pea, Blue Goose, Browneyed, Noname, Lady Pea. Write us if interested.

MIYID-Many farmers, especially in the South, prefer to grow the Cow Peas mixed, several varieties together, as they claim they get we re it that way.

CANADA FIELD PEAS-Very valuable for fattening stock, and can also be grown for soiling purposes. but is of greater value for fodder when fed as ground feed, or the vines can be cured for hay, which is of great nutritive value. They can be sown alone or with oats. If sown alone, sow 2 bushels to the acre. If with oats, sow 1 bushel of peas and $1 \frac{1}{2}$ bushels of oats. The latter method is the most profitable and a double crop can be secured at the same time. Threshed together they can easily be separated, but make a desirable feed when ground together for fattening stock.

\section{BERRY BOXES}

Anticipate your needs early. We carry in stock large quantities and can also make close price on car lots

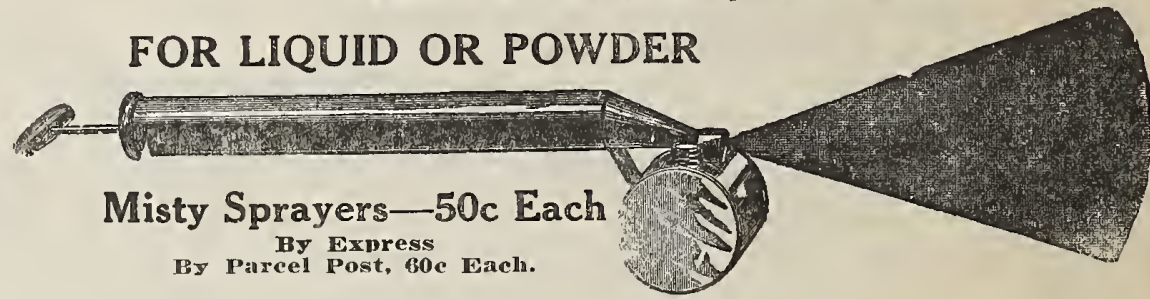

\section{BETTER CROPS IN'FIELD AND GARDEN IF YOU INOCULATE WITH}

Reg'stered in the United tates Dec. 6th, 1898. 26 YEARS AGO.
Awarded Gold Medal

Worlds Fair-St. Louis 1904. 20 YEARS AGO.

\section{THE ORIGINAL SOIL INOCULATOR}

Alfalfa, clovers, soybcans, vetches, peas, beans, cowpeas, peanuts and other legumes should always be inoculated ith Nitragin. The lack

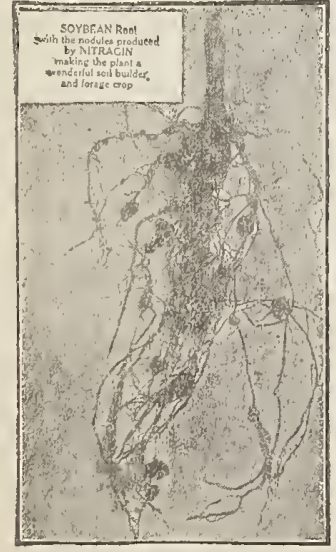

Inoculated Soybeans Be sure and name
crop to be inoculated.

\section{BENEFITS OF INOCULATION}

The principal reasons for inoculation can be stated in five short paragraphs, viz. ing in faster growth, earlier maturity and larger crops.

Second-Inoculated legumes take up more nitrogen than the plant itself requires, rplus remaining to the bencht of future crops.

Third-Inoculated lcgumes develop larger root systems than when not inoculated and therefore reach the immense stores of potash and phosphorus in the sub-soil, bring$\mathrm{ng}$ them up to supply the plant. When the roots and stubble decay these elements are also returned to the soil in a form available for future crops.

he Fourth-Inoculated legumes, by taking their nitrogen from ts nitrogen just the same as wheat or timothy or other leguminous Inoculated legumes contain more protein matter than when not inoculated, greatly increasing their feeding value.

improves its quality, enriches the soil and saves fertilizer

Prices For Field Nitragin

$1 / 4$-bu size inoculates $15 \mathrm{lbs}$ seed $\$ .40$

$1 / 2$-bu size inoculates 30 lbs seed

1-bu size inoculates 60 lbs seed .60

EVERY GARDEN NEEDS. "NITRAGIN" Garden size is for Peas, Sweet Peas and Beans,
1.00

75
Sold on the BUSHEL basis-not acre sizes. The one bushel size will inoculate one bushel of any legume seed, price $\$ 1.00$, other sizes in proportion. If you sow 15 pounds seed per acre. you pay $\$ .25$ per acre inoculating Sold in tins- not $\$ 1.00$ or more. a rich soil-like medium.

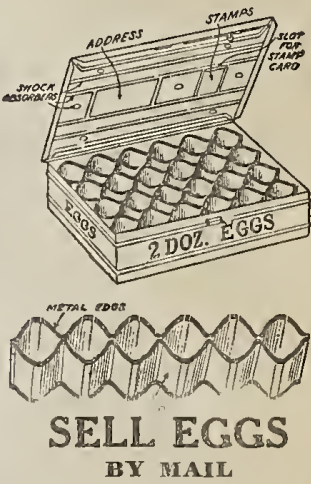

To your city friends shipped in

Aluminized Metal Egg Crotes

Indestructible; pays for itself in a few shipments; lasts for years; makes interchangeable shipping easy. Buy yours now and realize more money for your eggs. Your friends want them.

The Metal lige Filler is a wonder. A $\mathrm{n} e \mathrm{w}$ invention and can not be beat for safely carrying Eggs by mail. Light in weight but strong. Prices

2 doz. $\begin{aligned} & \text { Prices } \\ & \text { size.... \$1.50 }\end{aligned}$ 3 doz. size.... 1.75 4 doz. size.... 2.00 Add postage $10 \mathrm{c}$ 


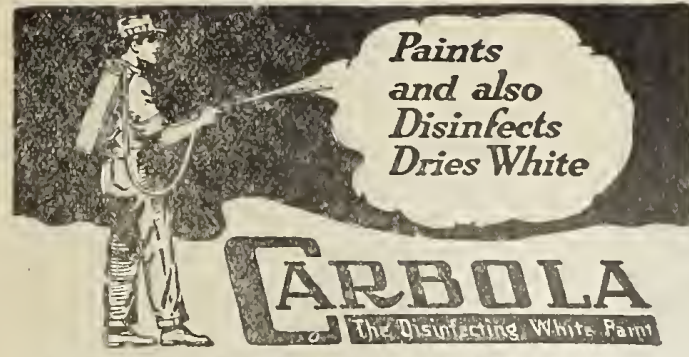

THE POUNDER OF MANY USES

CARBOLA is a white paint and powerful disin$\mathcal{C}$ fectant combined in powder form. It is ready to use as soon as it is mixed with water. It can be easily and quickly applied to building interiors with brush or spray pump. Disinfects and dries pure white. Does not flake or peel off. One pound covers $100 \mathrm{sq}$. ft.

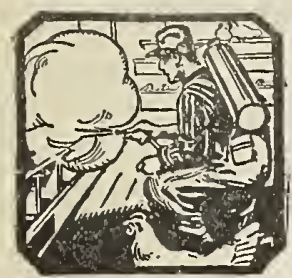

IN THE BARN

To paint and disinfect side walls, ceilings, stalls, etc., as an aid to cleanliness and prevention of tuberculosis, foot and mouth disease, and other contagious diseases. Spread the dry powder on floor Spread the dry powder on floor
where the cow stands. Use it as
a louse powder. Wash hands with powder before milking.

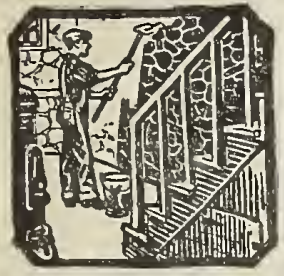

IN THE CHICKEN HOUSE

To paint and disinfect side walls, ceilings, roosts and brooders. Helps keep the birds free from lice and mites and the buildings clean, light and sanitary. Sprinkle it in the nests and rub it into the birds. The dry powder is an excellent louse powder.

Dust Carbola on rose bushes, peas etc., to help get rid of insects and worms. Spray it on trees and tree trunks.

It increases light, sanitation and general appearance in fac-
tory buildings. It makes cleaner warehouses. An excellent and tory buildings. It makes cleaner ware
economical interior finish for garages.

One pound of Carbola makes 1 gallon disinfectant whitewash and will cover 200 square feet.

Carbola is put up in the following sizes-with full directions how to apply on each package.

$13 / 4$ lb. pkgs. Each $30 \mathrm{c}$

5 lb. pkgs. Each $75 \mathrm{c}$

10 lb. pkgs, Each $\$ 1.25$

$50 \mathrm{lb}$. Bag Each $\$ 5.00$

By mail add $1 \mathrm{c}$ per $1 \mathrm{~b}$. plus $4 \mathrm{c}$, for postage.

With each $50 \mathrm{lb}$. Bag we will send you one of our High Grade Misty Sprayers FREE.

HYDRATED LIME-Hydrated lime used for top dressing on lawns and mixing soil for potting plants. $50 \mathrm{lbs}$. to cover 1,000 square feet. Price: 10 1b. bag, 30c; 50 lb. bag, 70c. Not prepaid.

By mail add $1 \mathrm{c}$ per $1 \mathrm{~b}$. plus $4 \mathrm{c}$, for postage.

NITRATE OF SODA-carries nothing but nitrogen (ammonia)-no phosphoric acid or potash. It is highly stimulating. On grass or other vegetation it is visible in a few days after application. Price lb., $15 \mathrm{c}$; 10 lbs., $\$ 1.25$; 50 lbs., $\$ 4.00 ; 100$ lbs., $\$ 7.00$. Not prepaid.

\section{LEG BANDS}

IMPROVED CHAMPION ADJUSTA-

BLE BAND-The most popular band on the market. Made in one size and adjustable to fit any fowl. Held by double lock. Made of aluminum. Doz., 15c; 25 for $25 \mathrm{c} ; 50$ for $45 \mathrm{c}$; 100 for $85 \mathrm{c}$, postpaid. If numbers are desired in rotation, 25 or more bands must be ordered.

SPIROL LEG BANDS-Mark your hens and pullets differently. Know what you are doing. Spirol bands are made of seasoned. celluloid. Last a life time. Slips on like a celluloid key ring. Birds cannot lose them. Light as a feather. Will not fade. Colors: black, white, dark blue, pink, light blue, red, green, yelow, purple. Prices: Doz., 15c; 25 for $25 \mathrm{c}$; 50 for $45 \mathrm{c} ; 100$ for $85 \mathrm{c}$, postpaid.

\section{FRUIT GROWERS' SPECIAL NOTICE}

Get our prices on spray material before you buy. We carry this in car lots and can supply you in Quantity and Prices as low or lower than it can be bought elsewhere.

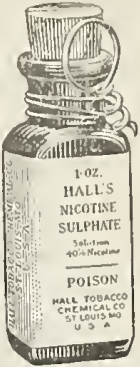

Nicotine Sulphate for Plant Lice, Worms and Bugs.

$1 \mathrm{oz}$. $35 c$

\section{TOBACCO} DUST

$1 \mathrm{lb} \ldots \ldots . . .10 \mathrm{c}$ 10 lbs.........75c Not Prepaid. For Dusting Vegetables and Flower Plants.

*ARSENATE OF LEAD (Powdered).

*BORDEAUX MIXTURE.

*PARIS GREEN.

CHECKER-1 lb. carton, 30c.

SLUG SHOT-1 lb. package, 30c

*LIME SULPHUR SOLUTION (Powdered).

*BLACK LEAF 40-1.

*FREE NICOTINE-1 oz., 35c.

*NICOFUME LIQUID-1 oz., 35c

NICOTINE SULPHATE SOLUTION.

*Cannot be sent through the mails.

MOLE KILLER-Eureka Mole Killer once. Small size, 50c; Large size, $\$ 1.00$. Postage extra.

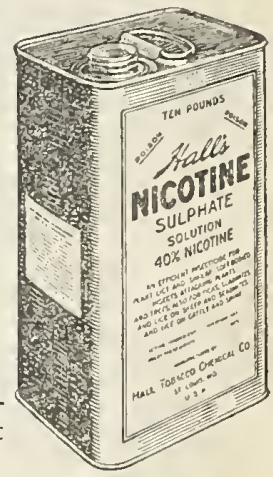

\section{SHEEP GUANO "Manure"}

We have been selling fertilizers for years and can recommend nothing better than Sheep Guano. Easy to handle. Put up in 100 lb. bags. SHEEP GUANO is a concentrated nautral plant food and soil builder. Convenient-easy to use grows. It is carefully prepared by an extensive process of direct heat, drving, sterilizing and grinding. A safe and derendable
fertilizer for finest landscape and garden use. and for all crops.

FOR LAWNS-It promotes strong healthy growth and a bright green velvety turf. 10 pounds for each 100 sq. ft. should be worked

into the soil before seeding or scatter broadcast over old lawn, and wet down. No weeds-no litter-quick and pleasing results are certain.

FOR FLowERs-shrubs-vines-trees, etc. Nothing else will produce foliage and force blooming like Sheep Manure. It's just what nature needs to make things grow. One pound for each 10 square feet of surface well mixed into the soil before planting, and 1 to 10 pounds dug in around vines, shrubs, trees, etc., is sufficient. Vary quantity depending on size and root development.

Mix one pound with each cubic foot of soil for potting or a pound to 5 gallons of water and set over night for watering once a week. Remarkable results auickly secured.

VEGETABLES AND FRUBT-These require the richest kind of soil to make them pay for time and labor. Sheep Manure is the best fertilizer for the home gardener or professional truck and fruit grower. Apply liberally and mix deeply into the soil before planting. Use 6 to 10 pounds for each 100 square feet. And apply side dressing around hills and along the row during growing season. It forces growth and increases production of all kinds of vegetables and fruits. Dig it into soil, bushes, vines and trees. The effects will show in a few days. or express. Tot prepaid. 


\section{FLOWER SEED--BULBS AND SHRUBS}

Choice Varieties From the Flower Gardens of the World

AEROCLIUM (Roseum) -2 feet. A pretty pretty bright rose with yellow center which can be dried. Pkt., 10c. Postpaid. AGERATUM-Flower light blue or lavender and white, desirable for bouquets, furnishing continuous bloom during the sumin winter. Pkt., 10c. Postpaid.

ALYSSUM-SWEET (Little Gem)-Very ingle plant will cover a space foot in diameter; blooms from spring until fall, very fragrant. Pkt., 10c. Postpaid.

AMARANTUS (Tricolor Splendens)-A hardy annual with leaves of red, yellow and green. Well known
Pkt., 10e. Postpaid.

\section{ASTERS}

VIOLET IKING-The habit of growth of this Aster is similar to the branching type. has long, stiff stems. Jn form the flower is entirely new and distinct from iny many of the flowers measuring from 4 to 5 inches in diameter. Petals somewhat resemble the quilled varieties, but are much
longer and broader. Pkt., 10c. Postpaid. GRAND PRIZE VICTORIA ASTERS-Magnificent flowei's, massive and showy, with the center. The flowers measure 4 to 5 inches across, and the colors include many shades. The plants grow very evenly, about 18 inches high, and carry from 25 handsomest Asters, taken all in all, for size, color and profusion of bloom. Pkt. CREG Postpaid. branc into bloom just ahead of the late type, affords variety in the garden. Pkt., 10e. Postmaid.

CREGO-Pink

CREGO-Crimson.

CREGO-Rose.

CRTGO-Purple.
Packet 10c. Postpaid.
DAYBREAK-This very desirable, medium early variety is a compact, upright growing, branching plant. Flowers borne on well formed and very double with regu larly incuryed petals. The color is a delicate light pink. Heig.

PLANTS-Budding out plants (Asters) on
sale after the first of May at 50e per sale after the

dozen, prepaid. Purple Scarlet, dark and rich; Sky-Blue, Pkt., 10c. Collection of 6 colors, 40e.

20TH CENTURY LATE BRANCHING-Withhas size, vigor, fine stems, beauty of form while not so early as many of the other varieties, it stands at the head of the list both for the home garden and as a florist's
flower. Carmine, Lavender, Pink or Rose,
Violet King, Crimson, Light Blue, Purple, May Semple (very light pink). Pkt. 10c; of above colors. Pkt., 10c. Postpaid.

BALSAM-Lady's Slipper. The seed of this popular old-fashioned annual should be sown in the house, or in the garden after the
ground has become warm. The plants do best in a rather light, ground has become warm. The plants do best in a rather light,
rich soil. They transplant readily, and the flowers are much finer if the plants have plenty of room; one foot apart each way is not
too much space for best results. Grown this way and given plenty of water the Balsam will make a splendid show and will remain in bloom for a long
height.

Camelia-flowered varieties. Superb double flowers in a variety of
colors as follows: White Perfection. Pkt. 5: Deen Scarlet, Pkt. 5e; Liglit Pink. Pkt., 5e; Mixed. Many fine shades. Pkt., 5e. Postpaid.

BALSAII APPLE-Very curious, rapid and dense climbers, with ornamental foliage and golden yellow fruit, which opens when
ripe, showing the seed and blood-red inside. Pkt., 5e. Postpaid. BACHELOR'S BUTTONS-(Centaurea Cyanus.) Our strain of this splendid annual is especially fine.
elor's Buttons. Pkt., se. Postpaid.

BRIZA MAKIMA-12 inches. Quaking: Grass. Valuable for winter bouquets and wreaths. The seed clusters are heart shaped and gracefully poised on such splendid stem. perpetual bloomer, the flowers are Oriental in color and exhibit every shade of yellow from ivory to the deepest orange. Makes good cut flowers and the dried stews. Pkt., 5e. Postpaid.

CANARY BIRD FLOWER-(Tronaeolum Canariense.) A beautiful climber with small Will bloom freely from July until killed by frost. Tender annual; height about 20 feet. Pkt.. 5c. Postnaid.

CANDYTUFT-(Giant Hyacinth-Flowered.) An improved strain, producins immense inches in length by 3 inches through. Very similar in shape to a Dutch Hyacinth. Fine for bedding and cutting. We offer the choicest sorts. Pkt., 5e. Postpaid.

GIANT WHITE-Pkt., 5e. Postpaid.

GIANT ROSE-Pkt., 5c. Postpaid.

LITTLE PRINCESS-Pkt., 5e. Postpald.

CANNA-(Madame Crozy.) Flowers beauti-

ful scarlet with gold border around each

Getal. Foliage Green. Pkt., 5e.
CARNATION PINKS-The various kinds of Carnation Pinks are all closely related to the greenhouse varieties of Carnations. All are deliciously iragrant, and all have the same narrow, grass-like foliage, All are pkt., 100. Postpaid.

Their bell-shaped flower

delicate coloring make Double and single mixed. Pkt. ARGUERITE-Like the winter blooming Carnation but bloom the first year from seed. A great variety of beautiful shades and fragrant doble flowers. Seeds should be sown inside to give longer season of bloom. Plants can be taken up in pots for winter blooming. Pure wh

like lajestic plants with palmgrounds and centers for beds best sorts mixed. Pkt., 5e; oz.,

There is beauty, brilliance and rapidity Cardinal Climber. Grows 30 fern-like foliage; literally covered from midsummer till nal red flowers, $1 \frac{1 / 2}{2}$ inches in of 5 to 7 each. Plant in a a notch in each seed to insure ELOSIA OR COCKSCOMBLasily grown annuals, fine for and llower beds, pot plants ELOSIA OR PLUMED COCKSCOMB-Mixed color's. Pkt., se; COMB VARINTIES Dware Mixed Colors.-Fine for BALLOON VINE-(I,Ove in " Puff) -A clean, free-growing vearine reaching 10 to 15 feet round, inflated seed-buds reballoons.

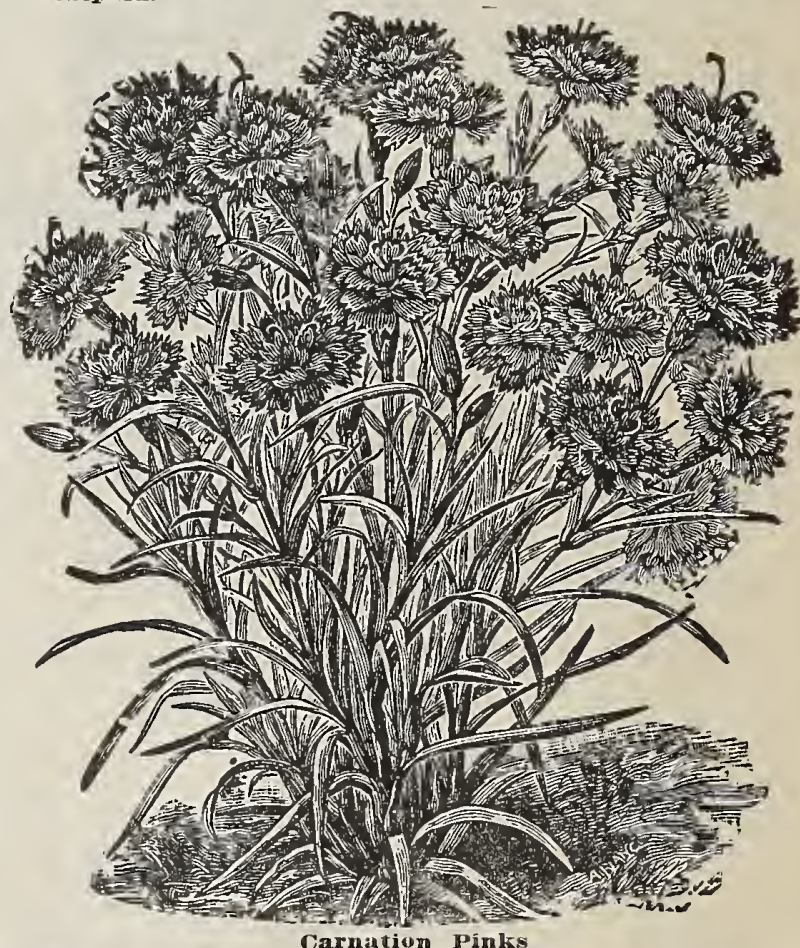

CHRYSANTHEMUM-Annual varieties, 2 feet. Showy and effective garden favorites, extensively grown for cut flowers. The hardy annuals are summer flowering border plants, good for pot culture and quite distinet from the autumn flowering varieties. Pkt., 5c. CALLIOPSIS, OR COREOPSIS-One of the easiest grown annual flowers; can be used with fine effect anywhere-in beds, borders or masses. Blooms all the time. Sow the seed thinly when weather becomes warm and soll dry. 1 to 2 feet. Pkt., 5c.

CINERARIA-Cinerarias are easily grown from seed in the greenhouse. The large heads of brilliant daisy-like flowers of many colors, usually sharply margined and with dark eye, are very desirable in pots. The plants are often as broad as high and the velvety leaves are shaded on the under side. Sow preferably early in fall. They thrive best in a mixture of loam and peat. Peren-

flowering. Pkt. 10c. growth, with fine foliage; flowers bell-shaped, almost one and onehalf inches across and two inches long. In good soil the stems often grow twenty to thirty feet long and cover a large surface. Plants begir flowering when quite young. Put the seed in barely moist earth, edge down, and barely cover with light soil. Do not Pkt., 10c. 


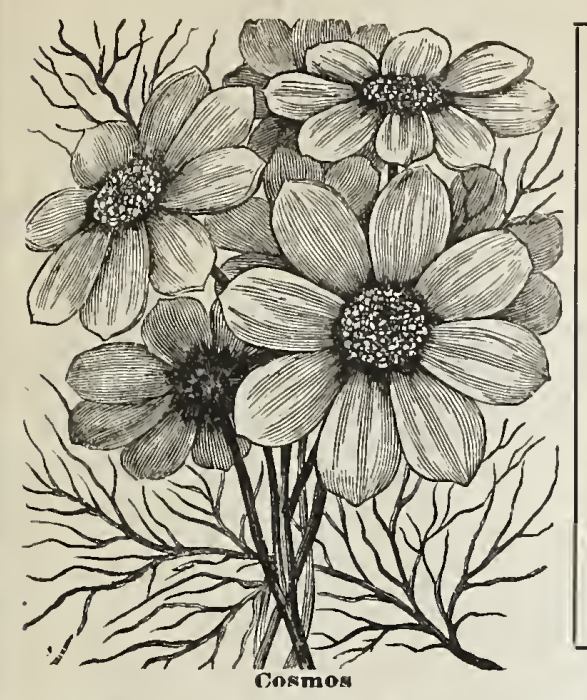

Cosmos-(Choice Double Mixed.) Beautiful and varied colors. Pkt., 10c. Postpaid.

GIGANTIC FLOWERING-This, the latest development in this popular autumn flower, bears gigantic flowers, with wide, overlapping petals of splendid substance. making a perrectly circular flower, which is borne on very long stems, in color a beautiful deep rosy-pink. The plant is of strong, vigorous growth, 6 to 7 feet high, $1 / 4$ oz., 40c. Postpaid. paid.

GIANT PINK-Light pink. Pkt., 10c. Postpaid,

ColwUs-One of the finest foliage plants grown from seed. Indispensable for borders and bedding. Sow early indoors and transplant. Our ding. Sow early indoors and transplant. Our seed will produce an endless variety
and markings. Pkt., 10e. Postpaid.

colUmBINE--(Aquilegia.) Blooms very early

in the season. Grows 2 to 3 feet in height.

Hardy perennial. Pkt., 5e. Postpaid.

CYPRESS VINE-(Ipomoea Quamoclit.) A most beautifu climber with delicate dark green foliage and an abundance of bright star-shaped, scarlet and white blossoms. White, Pkt. 10e; Crimson, Pkt, 10e; Mixed, Pkt., 10e. Postpaid.

DAFliA-If started indoors and transplanted outside when frost is gone, splendid sulccess may be had with dahlias, giving a profusion of bloom throughout the fall from spring-sown

seeds. Plat., 10c. Postpaid.
PEONY FLowteren-Bears enormous

blooms of many colors, generally semidouble, resembling peonies. The petals are curled and twisted. Blooms the Postpaid.

DOUBLE DAISY-One of the most charming of our early spring flowers. It is a perennial plant, quite hardy, easy culture, but requires shade. Pkt., 5c. Postpaid.

DAISY-SHASTA-A hardy perennial plant; blooms more abundantly each season; multiplied by division of root or sowing seed. They bloom for several months in great abundance. The flowers are large and graceful. with three or more rows of pure white petals. Cut and place days. Pkt., 5c. Postpaid. Plants, 20e each; \$2.00 per dozen. Not postuaid.

DIANTHUS or PINKS-New and choice varieties. This elegant family contains many of the most valuable and popular flowers in cultivation. All the sorts classed as annuals may be sown directly in the garden as soon as danger from frost is past, and will in a shor time become a mass of bloom, and so remain all summer. Elegant foot high and are of easiest culture. Pkt., 5e. Postpaid.

DoLICHos-(Hyacinth Bean.) A rapid growing annual climber flowering freely in erect racemes, followed by ornamental seedpods; for covering arbors, trellises, etc. Sow the seed in the garden in May where they are to remain. Pkt., 5e. Postpaid.

DIMORPHOTHECA AURENTIACA-(Golden Orange Daisy.) One of the newer annuals from South Africa. Grows 10 to 12 inches high. paid.

ESCHSCHoltzia-California Poppy. One foot. Sow seed where plants are wanted to bloom, as they do not transplant well. A bed of these brilliant flowers, when in bloom, give a very pleasing color effect. The foliage is finely cut and has a bluish tinge

FORGET-MF-NOT-Myosotis. Well known pretty flowers for borders and beds, their various shades being very effective. Pkt. 10c. Postpaid.

FOUR O'CLOCKS-Marvel of Peru. Open only in the afternoon or on first season. Hardy annual. Height 2 feet. Mixed colors. Pkt. 5c. Postpaid.

FoX GLOVE-Pkt., 5.c. Postpaid.

FEVFR FEW-Pkt., 10e. Postpald. ing period, - Blanket Flower. June to October, 2 feet. The long-flower uable of perennials, being easily grown in beds or borders in ordinary garden soil. Pktos se. Postpaid.

LOXINIA-A superb genus of greenhouse plants, produclng magnificen IYBRIDA (iRANUIFLORA-An unsurpassed strain., 10e. Postpaíd. SaTIA-Hardy annual about 1 foot high; single widely opened fiowers of in short dense spikes; suitable for pot culture or outyoor planting. Plkt.,

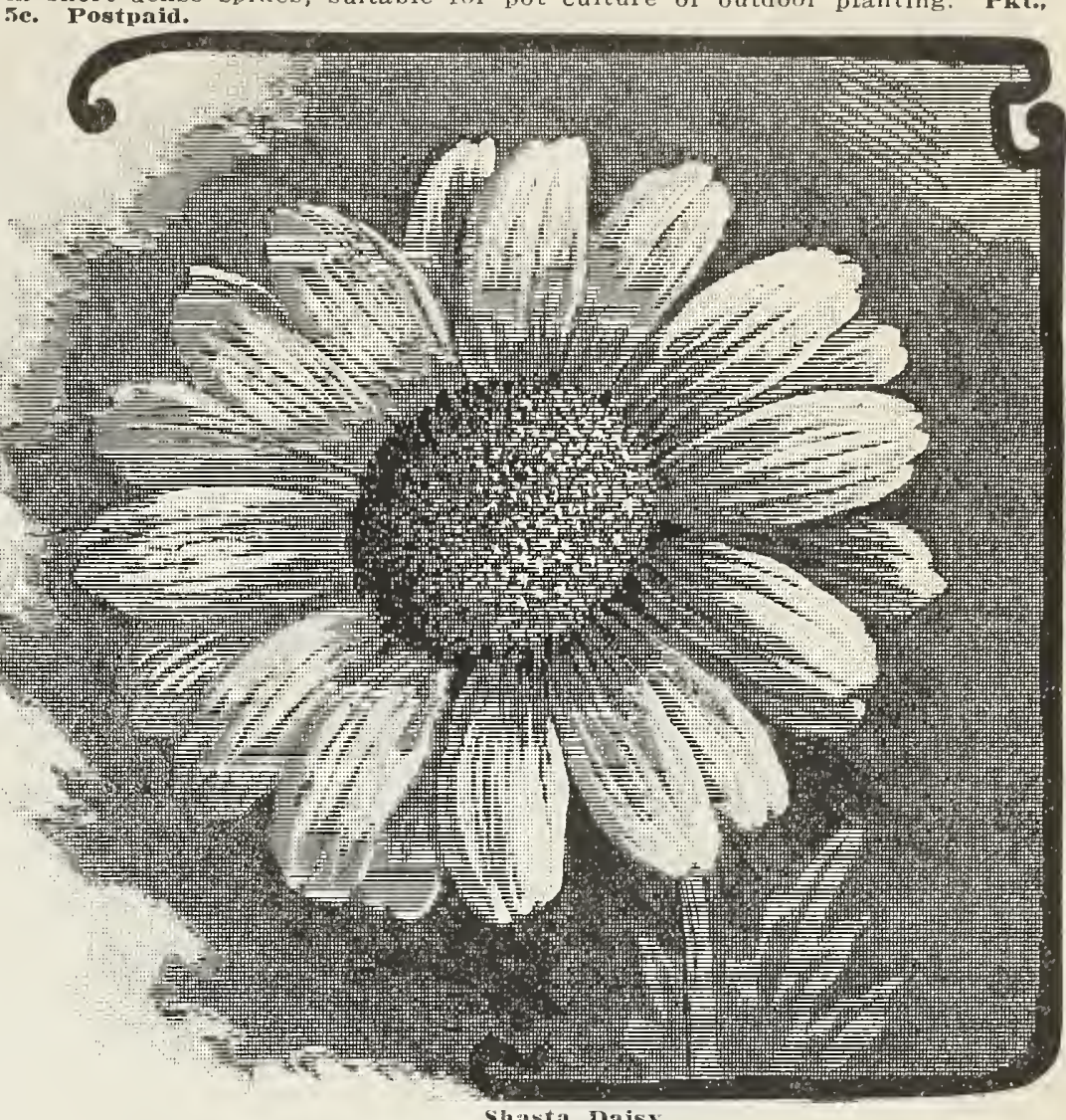

GERANIUMS-Extra fine mixture. Pkt., 10c. Postwaid.

GYPSOPHILA-(Baby's Breath) Dwarf-branching plants of quick growth and great freedom of blossom. The flowers are small, for cut flowers, as they lend sprays. which are highly esteemed for cut flowers, as they lend a most graceful effect when
bined in bouauets with Sweet Peas...Pkt., 10c. Postpaid.

Gourds-Mixed kinds. Pkt., se. Postmaid.

HELICHRYSUM-(Straw flower.) Very showy annual, unexcelled as a garden ornament or a winter decoration Double mixed varieties. Pkt., sc. Postpaid.

HLLIOTROPE-Great favorite with flower lovers for beauty or fragrance. Suited for beds or borders, where they will bloom in

summer and may be potted and cut back for winter blooming. Pkt. 10c. Postpaid.

HOLLYHOCK-No garden flower is more showy or admired. Double mixed. Pkt.. 10e. Postpaid.

HELIANTHUS, OR SUNFLOWER-A miniature Sunflower of a and hushy. Pkt.o we. Postpaid.

HIBISCUS-The colorings comprise rich dark red, soft mallow-pink and pure white; the plants grow from 5 to 8 feet high, blooming from early in June till late in autumn; and are perfectly hardy. Prepaid. Plyt., se.

ICE PLANT-A curious plant for hanging baskets, rock work, vases and edgings; leaves and stems succulent, appearing as though covered with crystals. Prepaid Pkt., 10c.

JAPANESE HOP VINE-Hardy climbers; small white flowers. Pkt., 5e. Postpaid.

JOB'S TEARS - (Coix Iachryma.) Curious ornamental grass with broad, corn-like leaves and seeds of a light slate color. Valuable for winter bouquets. with everlasting flowers. Strings of handsome beads are made from the seeds. Hardy annual; 3 feet high. Prepaid. Pkt,, 5c.

KOCHMA TRICOPHYLLA-(Summer Cypress.) A splendid ornamental annual plant forming dense oval bushes 2 to $21 / 4$ feet high, of small, feathery, light green foilage. As summer adA very this changes to a carn times. Also called "Burning Bush." Pkt., 10e. Postmaid.

KUDZU VINE-(Pueraria Thumbergiana.) A new climber of grea merit. This vine is one of the most rapid climbers there is,
growing to 20 feet quickly. Called als' Jack-and-the-Bean-Stalk. growing to 20 feet quickly. Called als
Hardy perennial. Pkt., se. Postpald. 


\section{FLOWER SEED--Continued}

LANTANA-The plants form small shrubs, producing in mer and autumn heliotrope-like clusters of single, fragrant flower's that change color. Succeeded by frost is over. May also be grown transplant when danger of about two feet high. Winest grown in pots. Tender perennial; Postranid.

LAHisle R-Dwarf, double mixed, Plik., 5e. Postpaid.

L.ARSPUIR-(Dwarf Germian Rocket.) An old and well-known annual. The flowers are borne in compact spikes, and are hardy,

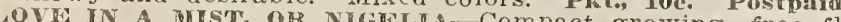

plant wis plant, with curioustooking flowers and seed pods. Pkt., 5e. OBELIIA.

very effective in masses, covered with bloom for a long season. Start in boxes and transplant. Easy to grow; 6 inches high. LARYy toe. Postpain.

perrennialorennial or Everlasting Pea.) A hardy perrennial climber, flowering the first year if seed is sown in the
fall. Leaves and stems smooth. Flowers resemble Sweet Peas, but are borne on strong stems, with 8 to 10 blossoms to the stem. is not fragrant, but is hardy and showy, and thrives in any good FriopHI.

bluepHLA-A hardy annual of dwarf habit, producing cheerful blue, violet and white flowers. Suitable for edges or borders.

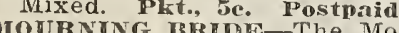

ONNING IBRDE-The Mourning Bride or Sweet Scabious of the old-time gardener but in every way improved. The blooms are ing from pure white to nearly black. Makes a grand colors ranging from pure white to nearly black.
Two feet high. Pkt., Je Postuail.

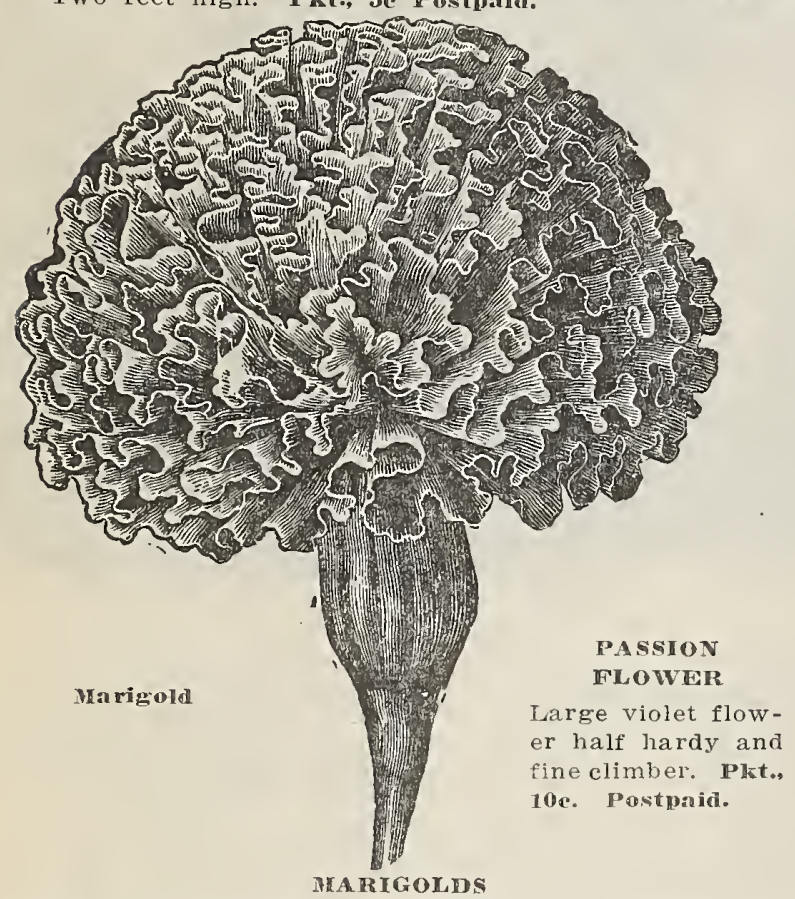

In autumn, when many bedding and other plants are past their prime, Marigolds afford a wealth of color that is simply invaluable. The African varieties produce large self-colored blos-
soms on tall plants; the French are smaller, but the colors and marking are very interesting some of the varieFrench and the Dwarf Single French Jarigolds hold the chief American Varieties.. Ilkt., je. Postpaid.

Afriean Varieties. Plkt.; be. Postpaid.

Fremch Varieties. Pkt., 10e. Postpaid.

PRIMULA CHINEsis-(Chinese Primrose.) Beautiful low growing spring flowering plant for borders or pot culture. Flowers are brone in clusters on stalks 4 to 8 inches high. Splendid mixed varieties. Pkt., 20c. Postpaid.

MIGNONETTE-In February and March sow in boxes and thin out to make strong plants. Beginning in March, sow at intervals outside for a succession: in late summer sow in pots or boxes for winter blooming. Fall sowings bloom early the next spring. Prefers cool location. Plant where they are to grow and thin out to stand 6 inches apart. Hardy annual. One foot high. 10e. Postpaid.

MORNING GLORY-Japanese Mornng Glories. Most beautiful of all Good vines and an abundance flowers. plkt., 5e. Postpaid

\section{USE} Slug Shot Tobacco Black Leaf 40, Tobacco Dust, For Bugs, Worms ari Red Spiner on your flowers, Rose Bushes and other Plants.

MOONFLOVVERS-The Ipomeas ((Moonflower) is one of the most vigorous summer climbers, growing under favorable conditions, 30 to 40 feet high. The large trumpet-shaped flowers often measure 4 inches across when widely extended. The seed have very lard outer shell which should be cut or filed through to insure germination. Annual. Plst., 10c. Postpaid.

CCOTIANA SANDERAE-New; a beautiful profuse flowering annual of bushy, branching. growth, 2 feet high, bearing large carPostpaid.

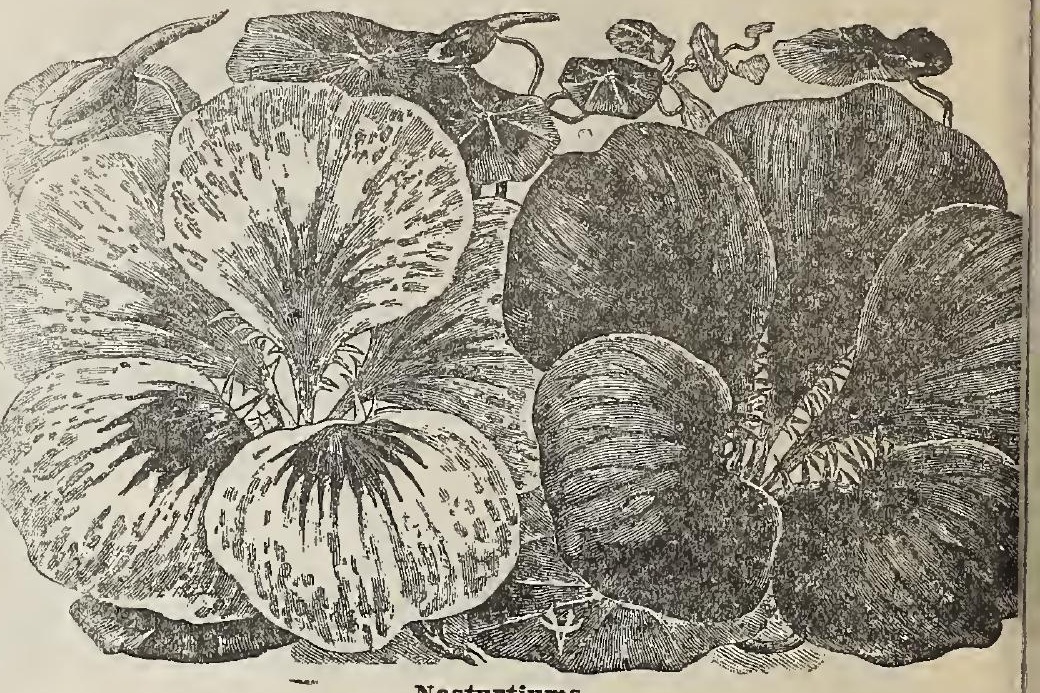
NASTURTIUMS

Tall or Climbing Varieties GIANT FLOWERING

Tlegant and luxuriant climbers for verandas, trellises, etc. May (user to cover unsightly railings and to trail over rough ground with fine ffect The seed pods tender for pickling: 6 to 10 feet.

Finest Mixed-Tall or climbing varieties. Pkt., 5e; oz., 20e; 1/4 Ib., 50e. Postpaid.

GIANT FLOUERING TOI THUMIR NASTURTIUMS

These Grand Bedding Nasturtiums have flowers ofter measuring 3 inches across, in a great variety of new and charming combinations of colors, while the brilliancy and velvety richness of the selfcolored sorts have been greatly enhanced. For summer flower beds nothing can surpass them; the plants form perfect mounds about 1 foot high by 1 foot across. Seed sown in the open ground in tho pring will produce plants that commence blooming during early

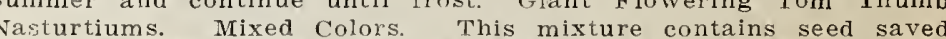
from the largest flowering. most beautiful and raried collection from the largest flowering, most beautiful

DAMGTG The Wonderful Colors of Pansies Makes Them Sow in Fall or Spring or Buy the Blooming Plants.

Gi in the Trimardean

Pansies. Mixed.

Giamt Caniary Mird.

Pure, spotless yellow.

Giant re King. Crimon-purnle and golden

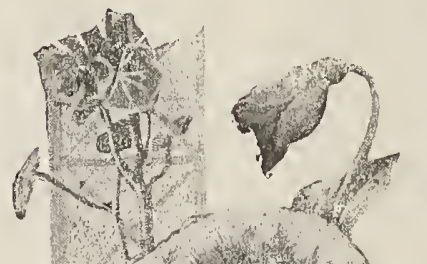

Giant Havane Brown.

light hrown.

Mannt Kins of the

black

field. nondom holio-

trope and nurn?

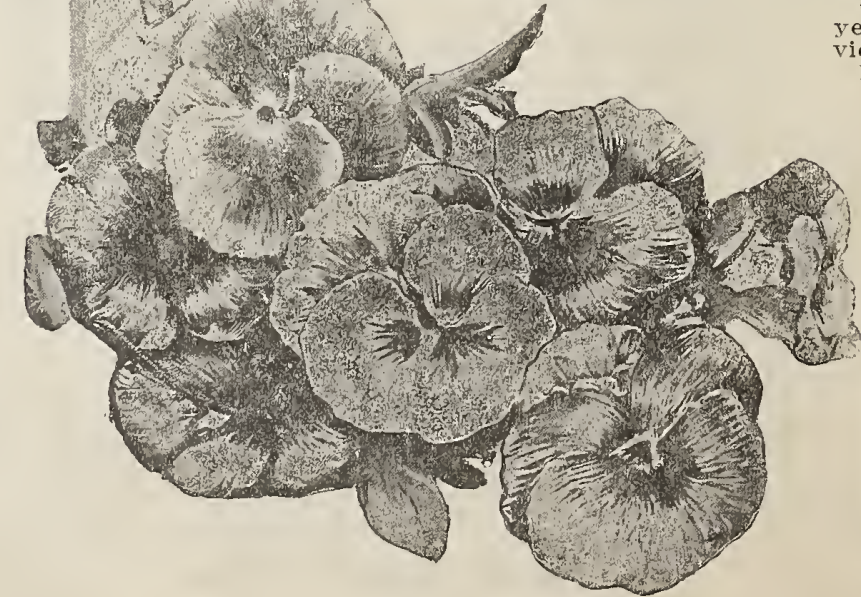

Giant Mhadame Perret. Wine color and white Giant Snow Queen. Spotless snow-white. Giant striped. White, blue, violet and choco-

Giant Violet Marbled Giant Violet Marbled

Yellow.

Giant Vietoria. Ox-

lood red.

Giant White Treas-

nre. White with three

Giant Yellow. Golden

ellow, three marnon

iolet blotches.

postpaid. 10c a pkt.

PANSY PLANTS

Mixed Colors of the choicest varieties.

50e doz. Postpand. 
Petunias-The richness of color, duration of bloom and ease of culture will always make petunias popular, especially for massing in beds. Flowers are large and borne profusely. For early flowers sow in boxes and transplant when weather is warm, or later sow outside in a sunny place. Height, 1 to 2 feet. Pkt., 10c.

\section{SWEET PEAS}

\section{Genuine Spencer Mixed, Postpaid Packel} 10c; Ounce 25c.

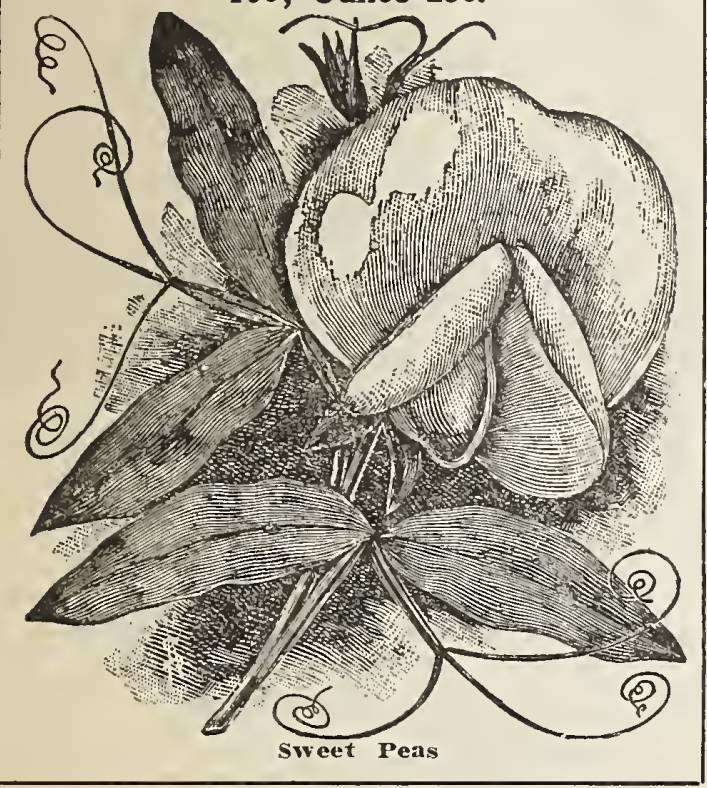

\section{POPPIES}

POPPIES (Shirley)-Beautiful poppies producing large single flowers, ranging in color from pure white shades of pink to glowing scarlet. Mixed colors. Pkt., 5c. Postpaid.

ICELAND POPPIES (Mixed) -..A graceful, delicate variety, with white, orange or yellow single blossoms, the petals resembling crumpled tissue paper. The plant is low-growing, but the stems are long and slender. Pkt., 10c. Postpaid.

POPPIES (Peony Flowered)-Flowers in size and color equal to peonies. Double and mixed varieties. Pkt., 5c. Postpaid.

POPPIES (Carnation Flowered)-Double. Fine mixed varieties. Pkt., 5c. Postpaid.

\section{PHLOX}

PHLOX DRUMMONDI GRANDHLOHAUnequalled in the magnificent display flowers. The plants are hardy blushtopped elusters of nearly round and topped clusters of nearly round and star-shaped flowers. They are of easier
culture and bloom profusely through 2 long season. Seed is usually sown very early in spring outdoors in rows 1 foot Well pulverized soil, preferably rich and Well pulverized soil, preferably rich and mellow, should be used and the seed, ered with about 1/4-inch of fine soil firmly pressed down. Pkto se. Postpaid.

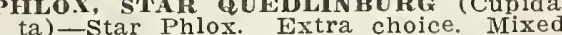
ta)-Star Phlox. Extr.

PANICULATA-Flowers white. A hard perennial which will stay in the

HARDY PHLOX (Phlox Decussata) plants for ts plants for beds or borders. Postpaid. finest sorts. Pkt., 10e. Postpaid. brightest in hot weather, when other flowers are drooping; they are of
CULTURE-Early in spring make a trench 3 to 4 inches deep, in rich mellow soil, so arranged that no water can stand in it, and plant the seed in the bottom, covering at first only 1 inch deep. When the plants are 2 inches high, cultivate and the vines to run upon. The roots should not be allowed to become too dry. Water applied thoroughly once or twice week, preferably early in the morning or in the evening, is will soon stop flowering.

These wonderful new frilled and wavy flowers are a distinct race of enormous flowered "Sweet Peas, passing the old "Grandiflora"

GVELYN HEmUS-Cream colored, a splendid flower. Pkt., 10e; oz.. $25 \%$.

MIRIAM BEAVER-This is last year's sensational novelty, a tiful varieties in existence. Plet. 15e.

WHITE SPENCER-The best white Sweet Pea so far offered. It has a very large fluted and crinkly standard. Flowers borne 3 and

APPLE BLOSSOII SPENCER-An exact reproduction of Apple Blos som and having the

KIVG EDVIRD VI SPENCER-The Grand Carmin

ered spencer. Flowers are deeply frilled. Pkt., 10c; oz., 25c.

HELEN LEUVIS-A true orange Spencer. Pkt., 10c; oz., 25e.

MRS. ROU'BZAHN-A beautiful blending of straw color tinted with blush pink and shad
oz., $25 \mathrm{c} ; \mathrm{T} / \mathrm{4}$ 1b., $75 \mathrm{c}$.

OTHELLO SPENCER-Of immense size with large, drooping wings and large wavy standard. Deep rich maroon. very dark and adapted

DAINTY SPENCER-Very large Spencer, white with rose-pink edges. Pkt., 15e.

COUN'TESS SPENCER-The original giant flowered Spencer, with finest waved standard wings. Clear pink. The first choice of all Sweet Peas. Pkt., 10c; oz., 25e; 1/4 Ib., 75e.

FLORENCE MORSE-A dark pink flowered Spencer. Pkt,, 10c; oz., 25e.

GEORGE HERBERT SPENCER-A new Spencer, bright rosy carmine in color. Pkt.. 10e; oz,, 25e.

PRIMROSE SPENCER-Morse's Extra Select Strain. The finest of its class, clear primrose color, fine large wavy standard and THNNANT SPENCEIR-A giant Spencer, rosy purple self. The very best variety of this shade. Pkt., 10c; oz., 25e; $1 / 41$ lb., $75 e$. as they gradually grow fill up the trench. When the plants usually better than light sprinkling more frequently. The CHOICE MIXED SUVET PEAS. Pkt.. 5e; ox., 10e; 1b., \$1.25. Postpaid. whade and color, and

brightest spots in the
garden. Large flowered.

garden. Large flowered.

handsome, double as a

pkt. ioc.

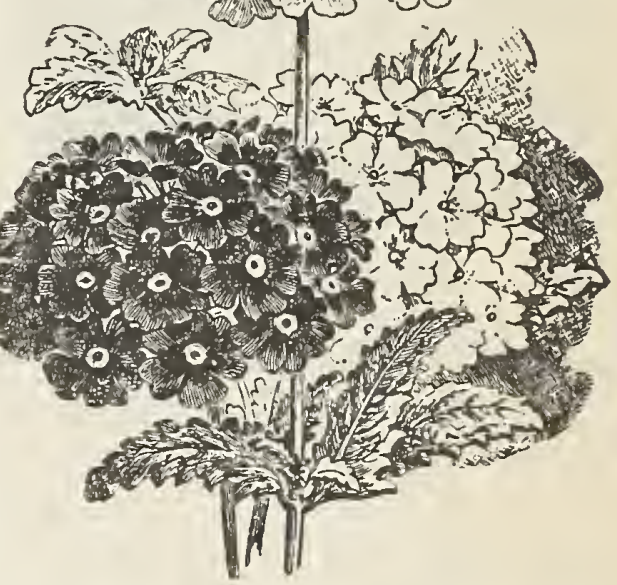

APORAGON OR AN'TIRRHINUM-Showy and useful border plants producing a great variety of brilliant flowers. Very effective in beds, to 3 feet. Mixed colors. Pkt., 10e. Postpaid.

EET TVLLIA - Makes an elegant display, producing a succession of llower clusters for several weeks, the colors varied, ranging from fli. fall sowing bloom the next summer. Height $11 / \mathrm{s}$ feet. Pkg. 10c. Postpaid.

OCKS (Gilliforer)-Useful annuals for bedding, borders, cut-flowers nd pot culture. Sow in February or March in the house, transplant made outside. Bear immense amount of fragrant blooms, each plant CVIA SPLENDENs (Scarlet Sage) -The Salvia splendens is a standard ding plant that keeps the garden bright with color until late in lant, does well in window boxes, and is useful for cutting to give 'THUNBERGIA, OR BLACK EYED SUSAN-A hardy annual climber growing about 4 feet long, and valuable for low fences or hanging

GBENA (Mammoth White)-This is by 11 white Verbenas. Pkt., 10c. Hixed Colors, Pkt., 5e.

RBENA HYBRIDA-The Verbena is deservedly a universal favor unrivalled in the splendor of its dazzling brilliancy of flower. UNNLOWER-Mammotla Russia-Pkt., 5e; 1/4 1b., 10e.

Double Yellow-Pkt., 5e: $1 / 4$ ih., $10 \mathrm{c}$

ZINNAAS-One of the most popular and satisfactory flowers that inost anywhere

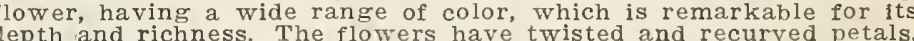
ong stiff stems, and are flowers have twisted and recurved petals, fine improved strain of these old fashioned flowers Plot 5 costmaid.

ZINNIAS-Cactus Flowered. 25e pkg. Postpaid.

ZINNIAS-Picotte Mixed. 25e pkg. Postpaid.

ZINNIAS-Dahlia Flowered. 25e pkg. Postpaid.

ZINNIAS-Crimson-Violet, Fancy Yellow Colors. Pink-White. 10e per pleg. Postpaid. 


\section{GLADIOLUS}

GLADIOLUS-Ready for Delivery After January 1st. Plant in Early Spring.

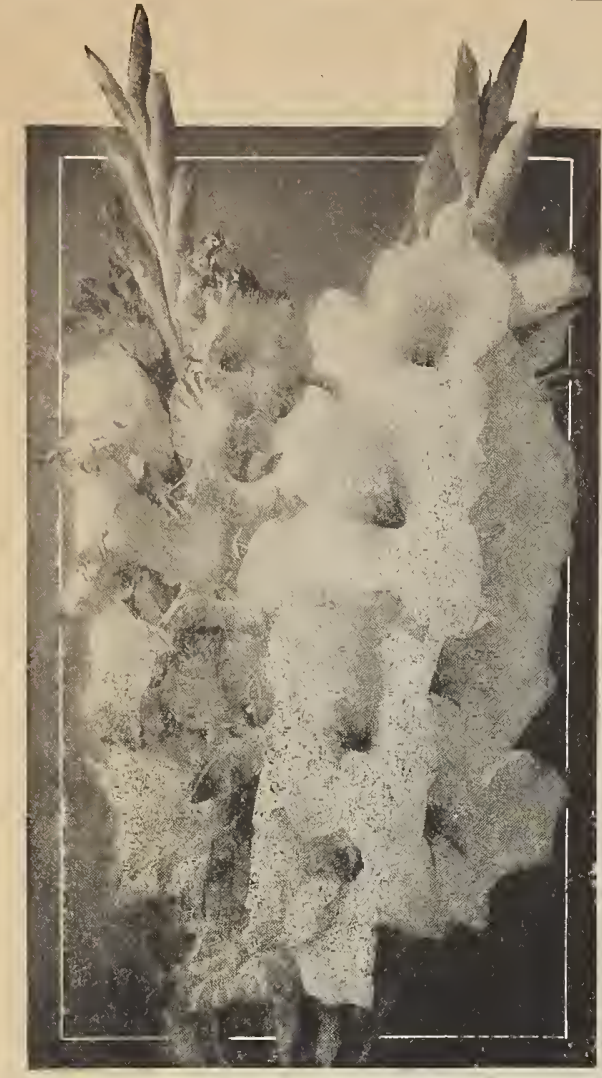

GOLDEN WEST-Brilliant orange with darker mottled throat. A superb flower. $7 c$ ea., 70c doz. Postpaid.

GAIETY-A real gay combination of colors, bright dark rose heavily flaked with white blotches and stripes. 10c ea., $\$ 1.00$ doz. Postpaid.
LE MARECHAL FOCH-A shade brighter than America. 7c ea., 70c doz. Postpaid. AMERICA-Soft, flesh. pink, lightly tinged with lavender; full round spike and large flower. Each 5c, dozen 50c, postpaid.

AUTUMN QUEEN-Cream yellow, red throat, late. 7c ea., 70c doz. Postpaid.

BARON HULOT-Deep violet blue-very popular. 10c ea. $\$ 1.00$ doz. Postpaid.

BLUE BIRD-Light blue with dark spot, with yellow center, very showy. $7 c$ ea. 70c doz. Postpaid.

CATHERINE-Beautiful light blue with darker blotch. 10c ea., \$1 doz. Postpaid.

CATLEYA-Soft lilac rose, lower petals spotted white. 6c ea, 60c doz. Postpaid.

CHICAGO WHITE-The flowers are well expanded, well placed upon the stalk, pure white with faint lavender streaks in the lower petals, 6c ea., 60c doz. Postpaid.

FLORA-Beautiful canary yellow with scarcely any markings; we consider the best yellow. 7c ea. 70c doz. Postpaid.

L'IMMACULEE-Undoubtedly. the best commercial white Gladioli in existence. Very tall spike, well set with tremendous large flowers of great substance. $7 \mathrm{c}$ ean 70c doz. Postpaid.

HALLEY - This is one of the earliest of Gladioli. Delicate salmon-pink, a pale ground showing at the throat, which is marked with small red stripes. Each 5c, dozen 50c. Postpaid.

\section{DAHLIAS}

The following list has been selected as being the best sorts for cut flowers.

Ea. Doz. ASIA, Soft Primrose, yellow........\$0.20 $\$ 2.00$ A. D. LOVINI, Show, soft pink.... $\quad .15 \quad 1.50$ ARABELLA, Show, pale lemon.... $.20 \quad 2.00$ DOROTHY PEACOCK, Show, pink

JACK ROSE Decorative, deep crimson

\section{CANNAS}

CHARLES HENDERSON-Bright crimson. $15 \mathrm{c}$ each.

FLORENCE VAUGHN-Yellow with red. 15c each.

QUEEN CHARLOTTE-Sicarlet center with orange. 15 c each.

BUTTERCUP-Golden yellow, 20c each.

ALL COLORS-Mixed, dormant, $10 \mathrm{c}$ each; $\$ 1.00$ dozen. Postpaid.

ROSEA GIGANTEA-Giant flowers of soft rose to carmine pink. The largest flowered pink Canna that we have ever seen. Height $3 \mathrm{r} / 2$ feet. 20c each. Postpaid.

YELLOW HUMBERT-Fine yellow, green foliage. Height $4 \mathrm{ft}$. 15c each, $\$ 1.50$ dozen. Postpaid.

KING HUMBERT-The Royal Red Canna. A brilliant orange scarlet with bright red shadings. Large trusses of blooms, the ndividual flowers being 6 inches in diameter Foliage a rich, reddish bronze, with lighter shadings. The finest red roliage and flowering variety grown. Height

For \$1.00 we will mail one strong root of each of the above varieties of finest Cannas by parcel post to any address postpaid.
MAUD ADAMS, Show, pure $\$ .20 \$ 2.00$ STORM Whing, Show, fine

SLYVIA, Decorative, white edged pink

YELLOW DUKE, Decorative, canary yellow

DAHLIAS-All colors, mixed...

AMERICAN BEAUTY-Yellow

ground, tipped with crimson...

All prices above postpaid.

\section{NEW CANNA}

THE PRESIDENT-4 ft. This immense new flaming scarlet has come into wider use more quickly than any other Canna. It is an offspring of the famous Firebird. The President leads the red varieties in the quality and also the quantity of its bloom. The flowers are 7 inches across; the individual petals are firm and long standing, and do not burn, and the trusses stand up stiff on strong stems. The foliage is rich green and burn-proof in the hottest weather. 20c each, $\$ 2.00$ dozen. Postpaid.

$\begin{array}{cc}\text { Peonies } & \text { Maderia } \\ \text { Red-White } & \text { Vine } \\ \text { and Pink } & \text { Tubers } \\ \text { Each 30c } & \text { 35c Dozen } \\ 3 \text { for 80c } & \text { Postpaid } \\ \text { Postpaid } & \text { WHITE } \\ \text { LILY OF THE } & \text { WMERYLLIS } \\ \text { VALLEY } & \text { 20c Each } \\ \text { 35c Doz. } & \text { Postpaid } \\ \text { Postpaid } & \end{array}$

white $15 \quad 1.50$
MRS. FRANCIS KING-Salmon red, very popular. 5c ea., 50c dozen. Pospaid.

MRS. FRANK PENDLETON-Pink carmine blotch, extra fine. 10c ea., $\$ 1.00 \mathrm{doz}$. Postpaid.

MYRTLE-A very delicate rose pink. Early. 10 c ea. $\$ 1.00$ doz. Postpaid.

NIAGARA-Cream yellow, fine flower. c ea., 60c dozen. Postpaid.

PANAMA-Pink. Each 7c, doz. 70c. Postpaid.

PEACE-A white flower, very large with pale violet feathering on interior petals flowers correctly placed on a tall graceful spike. Each 7c, dozen 70c. Postpaid.

PINK BEAUTY-Pale carmine, with large geranium blotch on lower petals. Very early. 7c ea., 70c dozen. Postpaid.

PRINCE OF WALES-Salmon-pink. Each 10c, dozen \$1.00. Postpaid.

SCHWABEN-A magnificent amber yellow, blotched in the throat and shaded with lemon yellow. A yery large bloom with six to eight open at one time. Plant vigorous and furnished with broad leaves. Each 8c, 80c dozen. Postpaid.

WAR-Large, tall, deep red, extra fine. $8 c$ ea., $80 \mathrm{c}$ doz. Postpaid.

WILBRINK-Flesh pink, creamy blotch in lower petals. 6c ea., 60c doz. Postpaid.

YELLOW HAMMER-Pure yellow, with red mark in throat. 7c ea., 70c doz Postpaid.

MIXED SHADES-All colors, 3 for 10c. 35e dozen. Postpaid.

\section{AMPELOPSIS VEITCHII}

BOSTON IVY-This is one of the finest climbers we know of for covering walls, as it clings firmly to the smoothest surface, covering it with overlapping leaves which form a perfect mass of foliage. The color is a fresh, deep green in summer, changing to the brightest yellow in autumn. It is quite hardy, and becomes per dozen. Not Postmaid.

SPIREA, VAN HOUTTEI-The grandest Spirea, and one of the finest shrubs grown? is of compact habit, and at the flowering season, in May and June, is a com phe fountain of white bloom, hardly made the foliage; the long racemes, made up of clusters of 20 or 30 white ing planting it cannot be surpassed cemetery feet tall plants. Each, 40c; \$4.00 per dozen, not postpaid.

\section{TUBEROSES}

EXCELSIOR DWARF PEARL-Rich, waxy white, very double and remarkably $\mathrm{fra}$ grant. 10c each; 75e dozen. Postpaid.

TALL DOUBLE-Flower spikes, $3 \mathrm{I} / \mathrm{s}$ to 5 foet high. First size bulbs. 10e, each; $\$ 1.00$ der dozen. Postpaid.

CINNAMON VINE-A Well known climber, brilliant glossy foliage, bears an abundance of fragrant flowers, often attain. a height of 20 feet. 30c a dozen. Postpald. 


\section{PARCEL POST}

Under ruling of the Postoffice Department we can send Seed by Parcel Post up to 70 lbs. in 1 st, 2nd and $3 \mathrm{~d}$ zones, and up to $50 \mathrm{lbs}$. to the 8th zone. This cheap method of delivery places the man who lives 100 miles away as close to market as he who lives in the city. Order Star Brand Seeds and have them at once, as we fill all orders the same day mail is received. See Parcel Post Rates on other side.

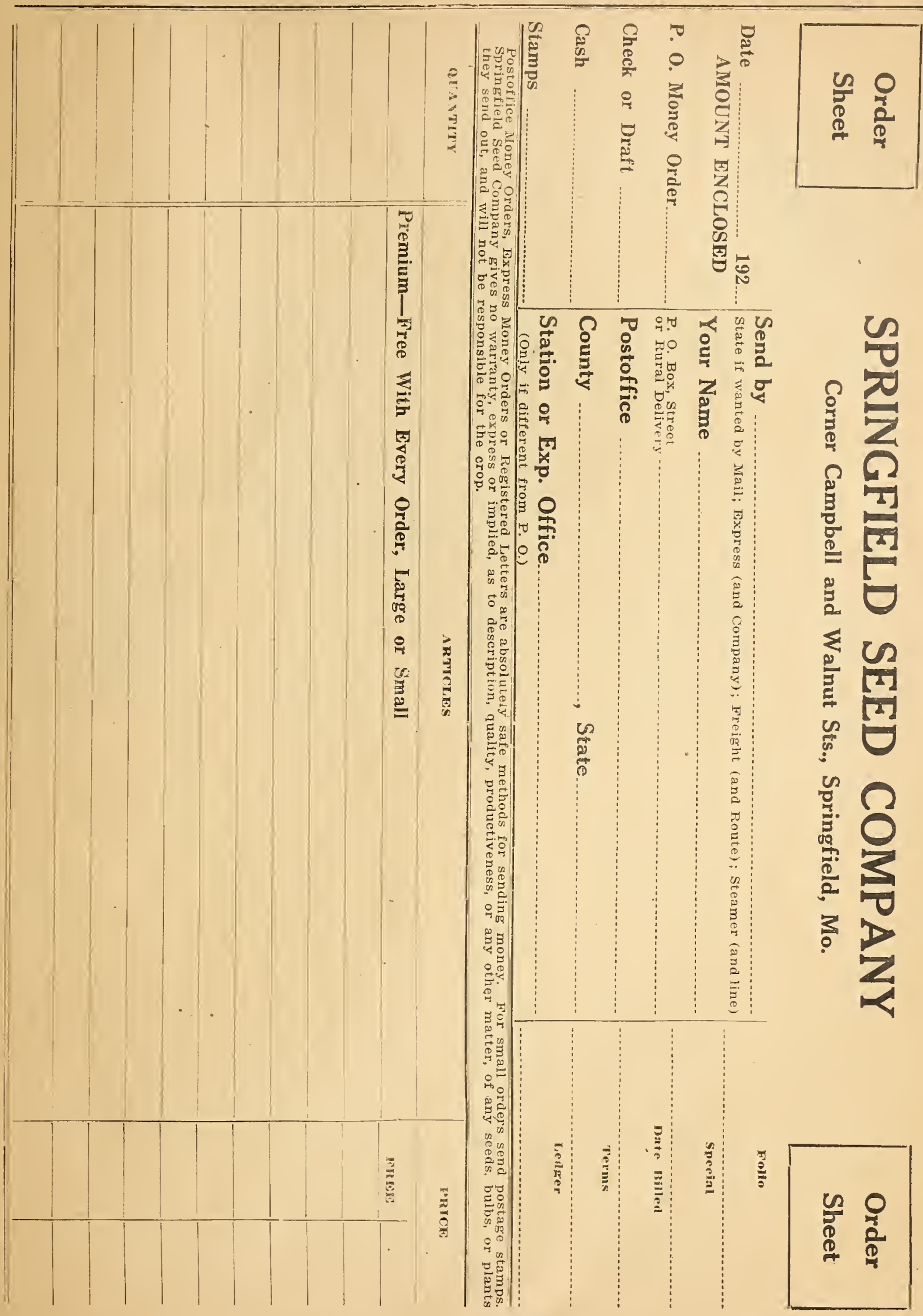


If you want to be first with new potatoes order a few Improved Early 6 Weeks.
DOMESTIC PARCEL POST RATES

On Seeds, Plants, Bulbs, Roots, Books, Tools, ete. vituin the U. $S$.

\begin{tabular}{|r|r}
$\begin{array}{c}\text { First } \\
\text { pound or } \\
\text { fraction }\end{array}$ & $\begin{array}{c}\text { Each } \\
\text { additional } \\
\text { pound or } \\
\text { traction }\end{array}$ \\
\hline $5 \mathrm{c}$ & $1 \mathrm{c}$ \\
$5 \mathrm{c}$ & $1 \mathrm{c}$ \\
$6 \mathrm{c}$ & $2 \mathrm{c}$ \\
$7 \mathrm{c}$ & $4 \mathrm{c}$ \\
$8 \mathrm{c}$ & $6 \mathrm{c}$ \\
$9 \mathrm{c}$ & $8 \mathrm{c}$ \\
$11 \mathrm{c}$ & $10 \mathrm{c}$ \\
$12 \mathrm{c}$ & $12 \mathrm{c}$
\end{tabular}

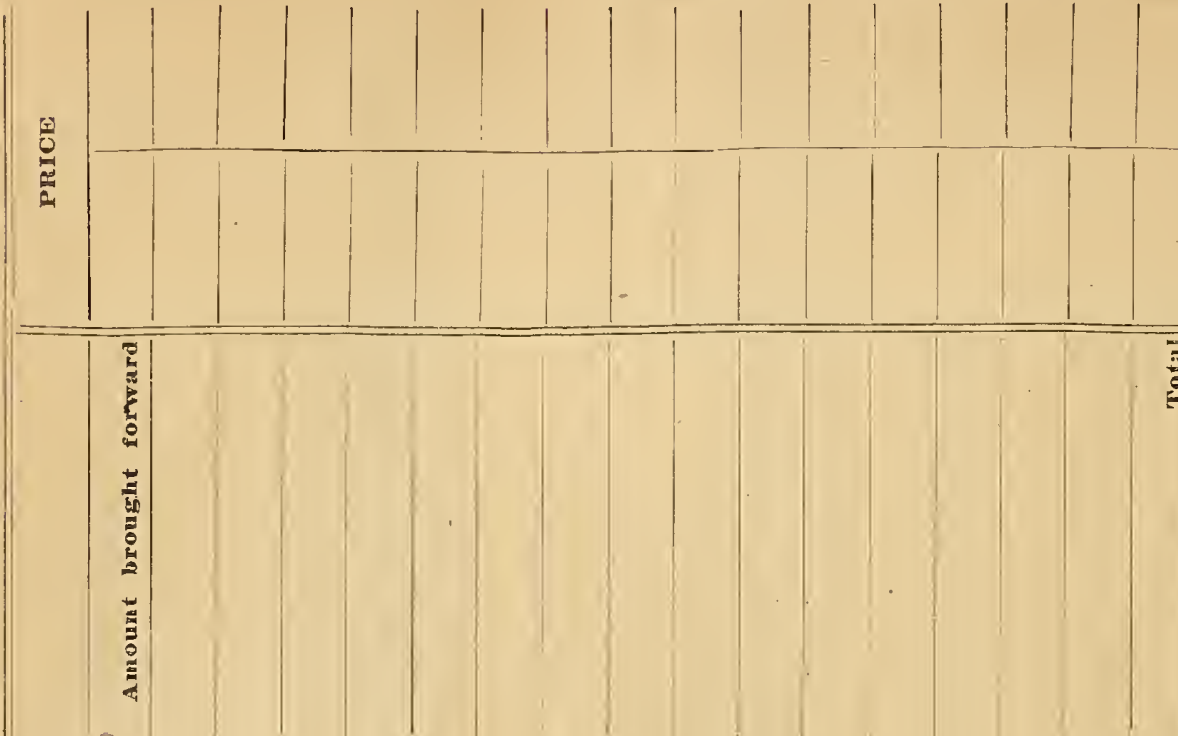

舅

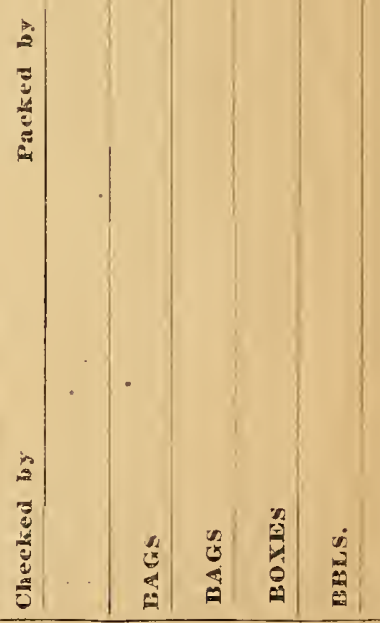




\section{KOSE DUNALS}

HARTY CLIMBERS Not Postpaid

CLIMBING AMERICAN HEAUTY-a seedllng from American Beauty with an admixture of Wichuralana and Tea blood. Same as its namesake in size and color and fragrance, with the addition of the climbing hablt. Better bloomlng qualities, good foliage and has proven hardy and withstood heat and drought. $75 \mathrm{c}$ each.

CHIMSON RAMBLER-Rapid grower and blooms in clusters, double crimson. each.

PINK RAMBLER W. EUPHHOSYNEBright pink; produced in lalge clusters; fine. 6oe ench.

YELLOWV RAMILER-B right yellow, changing to canary yellow; produced in pyramidal to canary soms. G0e each.

WHYTE RAMBLER-Small flower of pure white; produced in large clusters; fine. BOc each.

\section{FERTILIZER}

For Lawn, Garden and House Plants

GONE MEAL-For top dressing for lawns; also for use about fruit trees and bushes. It carries ammonia and phosphoric acid. One of the safest and most economical manures. Use 100 pounds to 1,000 square feet. Price: 100 lb. Bag, $\$ 3.00$ only. Not postpaid.

PULVERIZED SHEEP MANURE-As a top dressing for lawns there is nothing better. Promotes a steady and rapid growth in the vegetable garden. Price: 1 lb., 10c; 3 lbs., 25c; 50 lbs., $\$ 1.50 ; 100$ lbs., \$2.50. Not prepaid.

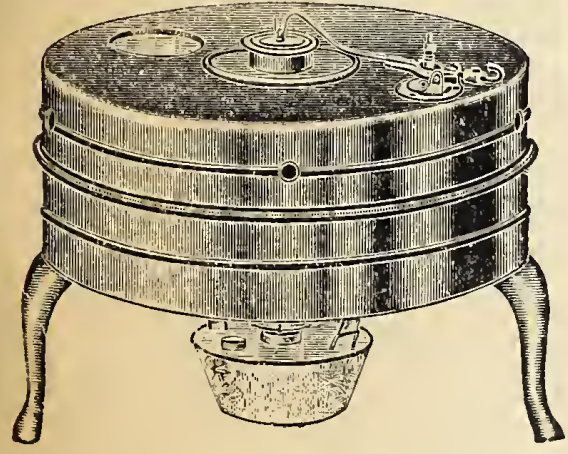

BABY GRAND INCUBATOR 50 Egg Size $\$ 7.50$

Now is the time to start in the Chicken Business.

1 gal. drinking fountain, $75 \mathrm{c}$ Peep of day chick feeder, $50 \mathrm{c}$ $1 / 2$ gallon shell box, $50 \mathrm{c}$ Dust Guns, $\$ 1.50$

\section{Postpaid.}

\section{$31 / 2$ gal. Auto Pressure} Sprayer, $\$ 9.50$ by express.

\section{ELERHANI}

CALADIUM-One of the most effective plants in cultlvation, for planting out upoll tile lawn. It can be made to produce three to ten handsome leaves, oiten five feet long and thirty inches wide. You cannot make the soll too rich or keep it too wet Fine bulbs with live center shoots. Fine bulbs bulbs. $11 / \%$ to $21 \%$ inches in diameter. cach 15e.

Select size bulbs, $2 \%$ to 3 inches in al ameter, each 30 .

Ionster size bulbs, 50 each. Pootprid.

\section{HYDRANGEA.}

HYDRANGEA GRANDIFLORA-Indeed it is the finest shrub in cultivation. Flowers are formed in large white lusses 5 to 10 inches ln length, remalnflowers turn rosy pink in the fail. It is as hardy as an oak and a profuse bloomer. It is by all means the very best hardy shrub we know of and cheerfully recommend it. 2 to 3 feet tall, plain white. Each, 50e; $\$ 5.00$ per

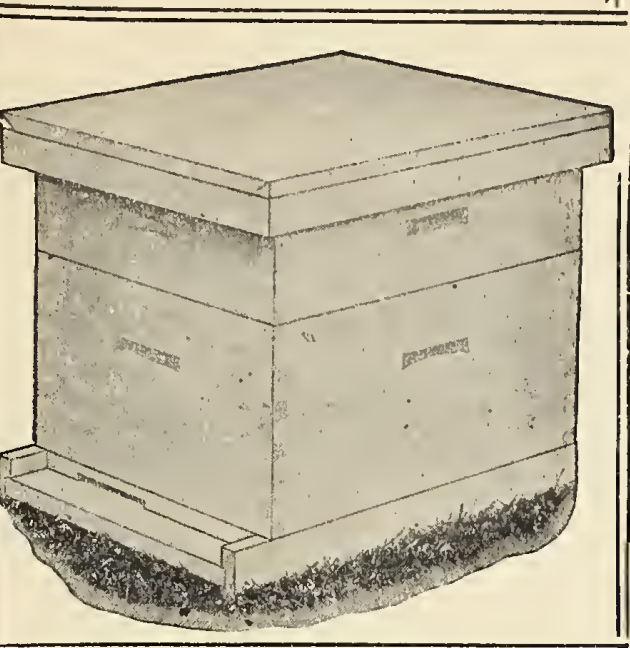

\section{POULTRY FEED}

Star Hen Feed

Knife Chick Feed

Pigeon Feed

Meat Scrap

Fine Bone

Medium Bone

Coarse Bone

Oyster Shell

Blood Meal

Flaxseed Meal

Medium-Fine and Coarse Charcoal

As prices change weekly on feed stuff we cannot make a catalog price good for any length of time. Write for prices.

Write for Our Special Catalog on

Spring Buibs, Rose Bushes and Shrubs of all Kinds. produced in great p.

hardy climber in cultivation. Fach r5e IPostogid.

\section{PRIVET-(For Hedge)}

AMOOR RIVER HARDY I'RIVIET-A strong GTOWIng variety, of fine habit and the most popular of all hedge plants. If cut to the ground one or two years after plantlng, it makes a very thlck hedge right from the bottom. Leaves remain green almost all wlnter if slightly shelpaid: $\$ 8.00$ per hundred, not postpaid.

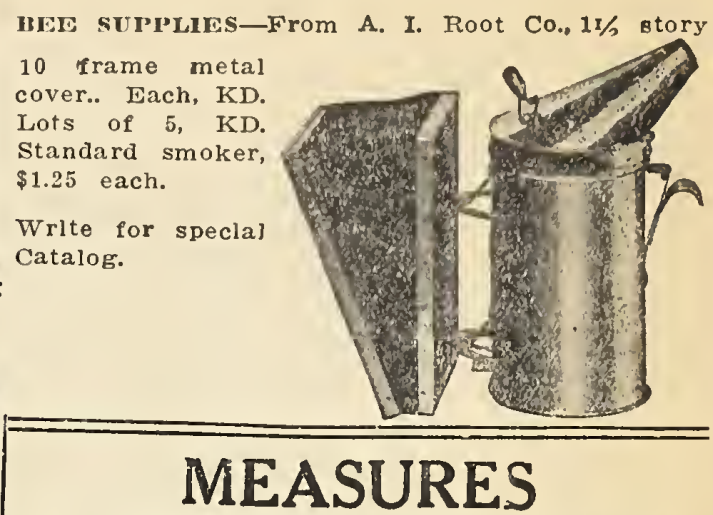

AND AMOUNT OF SEED SOWN TO THE ACRE Pounds Pounds

lfalfa_broadcast. . ........ per acre $18-22$ Lbs. 60 Lbs. lfalfa-drilled. arley in hilis lue Grass, Kentucky.

Brome Grass-alone for hay. rome Grass-alone for pas

Broom Corn

flover, Alsike-aione

forage. Alsike-..............

Clover, nammoth ...............

Clover, Red-alone for forage

Clover, Red-on small grain.

Clover, Sweet-hulled

Clover, Sweet-unhulled.....

Clover, White

Corn.

Cow Peas-drilled

Canada Fleld Peas-broad-...

cast. . . . . ..............150-160

oats.

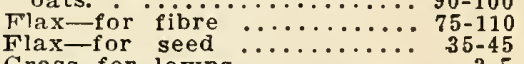

Grass for lawns ............

Hungarian Mlllet-for hay.
Hungarian Millet-for seed.

Johnson Grass

Kaffir二for fodder...............

Meadow Fescue

Millet, common, for hay...

Millet, common, for seed.

Millet, Golden, for hay.

Millet, Golden, for seed.

Millet, Siberian, for seed.

Millet, Japanese

Oat Grass, Tall

Orchard Grass

Pasture Mixture

Rape, in drills

Rape, broadcast

Rye.

Rye.

Rye frass, Italian

Rye Grass, Perennial

Sheep's Fescue

Sorghum forage. broadcast. Sorghum, for seed or syrup.

Soy Beans, drllls

Soy Beans, broadcast ..........

Sweet Corn, drills for fodder

Sweet Corn, broadcast

Sudan.

Tlmoth. ...............

$5-110$

20-35

$35-40$

$18-20$

$20-25$
36

60-70

$8-15$

$4-8$
$12-15$

16
$8-14$

$20-30$
$30-40$

(15

$\begin{array}{rl}3-5 & \mathrm{Bu} . \\ 40 & \mathrm{Lbs} .\end{array}$

25
$25-30$

$25-30$
$3-8$

$10-12$

15-20

40

25
40
25

40
25

15
30

$70-100$

$25-35$

$40-42$

$2-4$
$4-8$

$14-18$

$55-65$

$75-200$
$40-50$

$40-50$

$35-45$

$75-100$

$2-5$

$30-40$

$60-80$
75

16-24

$16-24$
$15-25$

Veteh, hairy, drroadcast....... 90

vetch, Spring, (plus 1 bu. small grain) $\quad . . . \ldots \ldots \ldots$.
60

60

14

14

14

60

60

60

60

33

50

56

60

60

60

60

56
56

56

48

25

$\mathbf{5} 0$
$\mathbf{5} 0$

20

50

50

50

50

35
14

32 


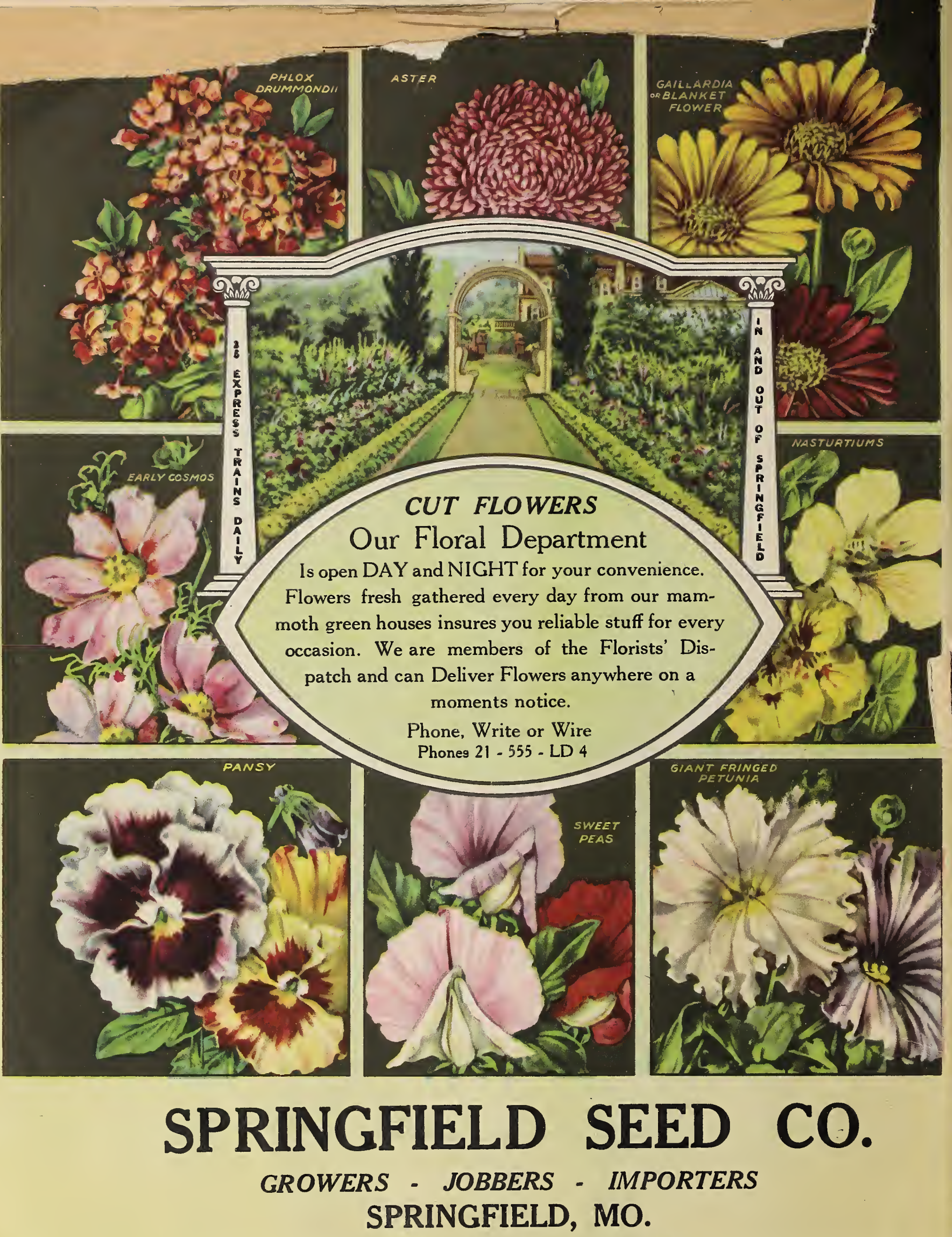

Corner Campbell and Walnut Streets 